Andrews University

Digital Commons @ Andrews University

\title{
A Study of the Beliefs, Knowledge Levels, and Sexual Behavior as They Relate to HIV/AIDS of Students Attending Three Seventh-day Adventist Boarding Schools in Ethiopia
}

Debora Herold

Andrews University

Follow this and additional works at: https://digitalcommons.andrews.edu/theses

Part of the Secondary Education Commons

\section{Recommended Citation}

Herold, Debora, "A Study of the Beliefs, Knowledge Levels, and Sexual Behavior as They Relate to HIV/ AIDS of Students Attending Three Seventh-day Adventist Boarding Schools in Ethiopia" (1999). Master's Theses. 160.

https://dx.doi.org/10.32597/theses/160

https://digitalcommons.andrews.edu/theses/160

This Thesis is brought to you for free and open access by the Graduate Research at Digital Commons @ Andrews University. It has been accepted for inclusion in Master's Theses by an authorized administrator of Digital Commons@Andrews University. For more information, please contact repository@andrews.edu. 


\section{ABSTRACT}

\section{A STUDY OF THE BELIEFS, KNOWLEDGE LEVELS, AND SEXUAL BEHAVIOR AS THEY RELATE TO HIV/AIDS OF STUDENTS ATTENDING THREE SEVENTH-DAY ADVENTIST BOARDING SCHOOLS IN ETHIOPIA}

by

Debora Herold

Chair: Jimmy Kijai 


\title{
ABSTRACT OF GRADUATE STUDENT RESEARCH
}

\author{
Thesis
}

Andrews University

Interschool Interdisciplinary Graduate Program

Title: A STUDY OF THE BELIEFS, KNOWLEDGE LEVELS, AND SEXUAL BEHAVIOR AS THEY RELATE TO HIV/AIDS OF STUDENTS ATTENDING THREE SEVENTH-DAY ADVENTIST BOARDING SCHOOLS IN ETHIOPIA

Name of researcher: Debora Herold

Name and degree of faculty chair: Jimmy Kijai, Ph.D.

Date completed: July 1999

\section{Purpose}

The purpose of this study was to determine the beliefs and level of knowledge about HIV/AIDS, and sexual behavior of students attending three Seventh-day Adventist (SDA) secondary schools in Ethiopia. This study also examined how certain demographic characteristics were related to the student's beliefs, knowledge level and sexual behavior.

\section{Method}

An adapted version of the AIDS Survey for Students developed by the U. S. Centers for Disease Control was administered during assembly to students of three SDA secondary schools in Ethiopia. One thousand one hundred and forty-four completed the 
survey. Chi Square was used to test the null hypotheses implied in 19 research questions. Statistical significance was set at 0.05 .

\section{Results}

A majority of the students have correct knowledge of HIV/AIDS and have positive attitudes towards victims of AIDS. Grade levels, age, and gender were significantly related to a number of beliefs and attitudes about HIV/AIDS. Affiliation with the SDA church as well as length of attendance at SDA schools were also significantly related to some beliefs and attitude items. There is also significant relationships between sexual behavior and communication with parents or other adults about HIV/AIDS.

\section{Conclusions}

There is no cure for HIV/AIDS in the foreseeable future. Sex and AIDS education should be developed to encourage responsible sexual behavior. 


\author{
Andrews University \\ Interschool Interdisciplinary Graduate Program
}

\begin{abstract}
A STUDY OF THE BELIEFS, KNOWLEDGE LEVELS, AND SEXUAL BEHAVIOR AS THEY RELATE TO HIV/AIDS OF STUDENTS ATTENDING THREE SEVENTH-DAY ADVENTIST BOARDING SCHOOLS IN ETHIOPIA
\end{abstract}

\author{
A Thesis \\ Presented in Partial Fulfillment \\ of the Requirements for the Degree \\ Master of Science in Administration
}

by

Debora Herold

July 1999 

A STUDY OF THE BELIEFS, KNOWLEDGE LEVELS, AND SEXUAL BEHAVIOR AS THEY RELATE TO HIV/AIDS OF STUDENTS ATTENDING THREE SEVENTH-DAY ADVENTIST BOARDING SCHOOLS IN ETHIOPIA

A thesis

presented in partial fulfillment

of the requirements for the degree

Master of Science in Administration

by

Debora Herold

APPRONAL BY THE COMMITTEE:
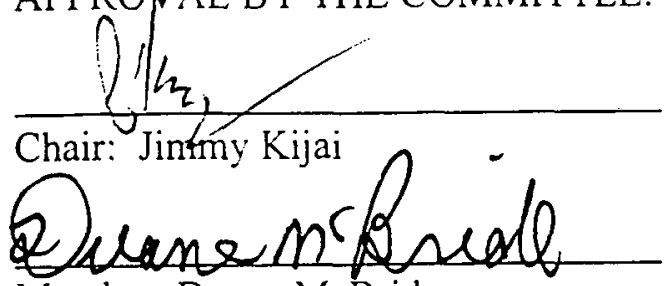

Member: Duane McBride
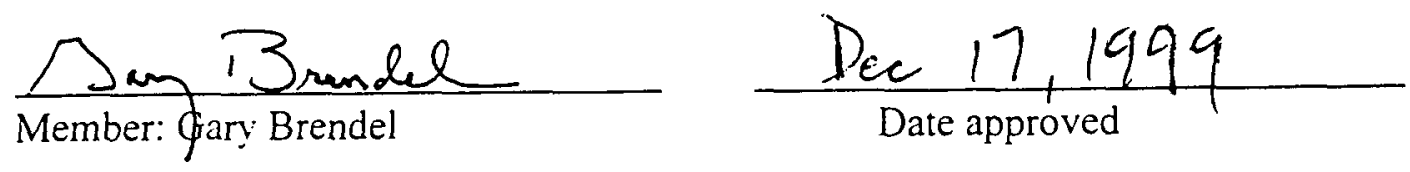
To my husband, children, and many friends who always encouraged me, believed in me, and exercised patience and tolerance 


\section{TABLE OF CONTENTS}

LIST OF FIGURES $\ldots \ldots \ldots \ldots \ldots \ldots \ldots \ldots \ldots \ldots \ldots \ldots \ldots$ vii

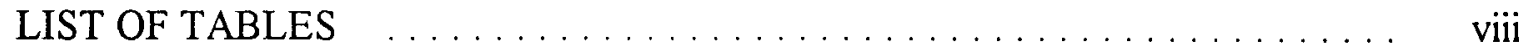

ACKNOWLEDGMENTS $\ldots \ldots \ldots \ldots \ldots \ldots \ldots \ldots \ldots \ldots \ldots \ldots$

\section{Chapter}

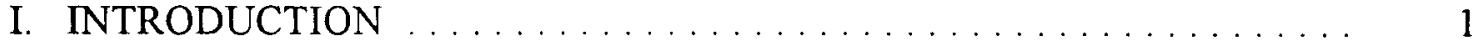

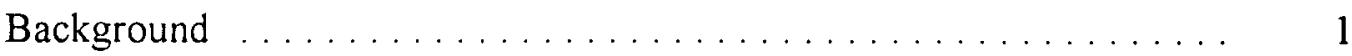

Purpose of the Study ........................ 5

Significance of the Study . . . . . . . . . . . . . . . . . . . . . 7

Limitations of the Study $\ldots \ldots \ldots \ldots \ldots \ldots \ldots \ldots$

II. REVIEW OF LITERATURE $\ldots \ldots \ldots \ldots \ldots \ldots \ldots \ldots \ldots \ldots \ldots$

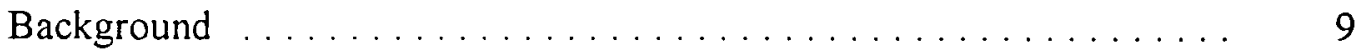

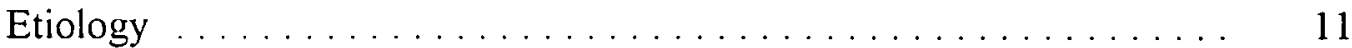

International Scope .......................... 13

National Scene ............................... 14

Ethiopian Scene . . . . . . . . . . . . . . . . . . . . . . . 17

Adolescent Scene ... . . . . . . . . . . . . . . . . . . . . . . . 19

Summary of Literature Review . . . . . . . . . . . . . . . . . . 25

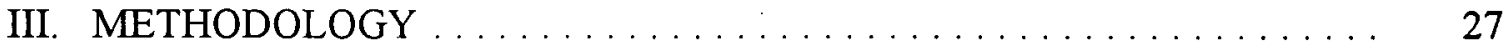

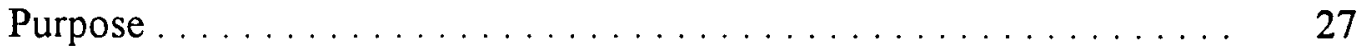

Research Design . . . . . . . . . . . . . . . . . . . . . . . . . . 27

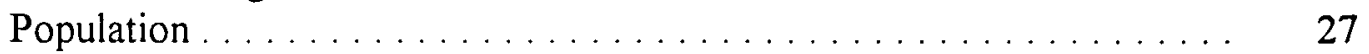

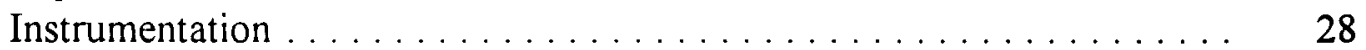

Survey Administration . . . . . . . . . . . . . . . . . . . . . . . 29

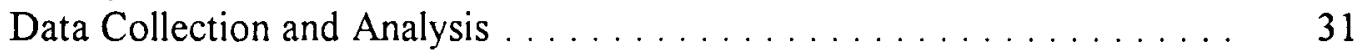

Summary ........................... 32 


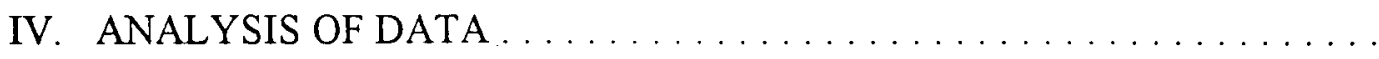

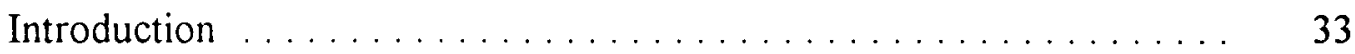

Description of the Sample ...................... 33

Descriptive Results ............................ 34

Research Question 1

Beliefs towards HIV/AIDS . . . . . . . . . . . . . . . . $\quad 34$

Research Question 2

Knowledge level regarding HIV/AIDS $\ldots \ldots \ldots \ldots \ldots \ldots \quad 38$

Research Question 3

Sexual behaviors in relation to HIV/AIDS $\ldots \ldots \ldots \ldots \ldots .42$

Research Question 4

Relationship between grade level and beliefs towards HIV/AIDS . 44

Research Question 5

Relationship between grade levels and knowledge level regarding

HIV/AIDS

Research Question 6

Relationship between grade levels and sexual behavior ....... 53

Research Question 7

Relationship between age and beliefs towards HIV/AIDS . . . . . .

Research Question 8

Relationship between age and knowledge level regarding

HIV/AIDS

Research Question 9

Relationship between age and sexual behavior ...........

Research Question 10

Relationship between gender and belief towards HIV/AIDS .....

Research Question 11

Relationship between gender and knowledge level regarding

HIV/AIDS

Research Question 12

Relationship between gender and sexual behavior in relation to HIV/AIDS

Research Question 13

Relationship between Seventh-day Adventist religious affiliation and belief towards HIV/AIDS

Research Question 14

Relationship between Seventh-day Adventist religious affiliation and knowledge level in relation to HIV/AIDS . . . . . . . . .

Research Question 15

Relationship between Seventh-day Adventist religious affiliation and sexual behavior in relation to HIV/AIDS . . . . . . . . . .

Research Question 16

Relationship between years of attendance at Seventh-day

Adventist boarding schools and beliefs towards HIV/AIDS 


\section{Research Question 17}

Relationship between years of attendance at Seventh-day

Adventist boarding schools and knowledge level in relation to HIV/AIDS

Research Question 18

Relationship between length of attendance at Seventh-day

Adventist schools and sexual behavior in relation to HIV/AIDS ..

Research Question 19

Relationship between the extent to which students talk to

their parents or another adult and sexual behavior in

relation to HIV/AIDS ... . . . . . . . . . . . . . . . . . . . . . 88

Summary 88

V. SUMMARY, DISCUSSION, CONCLUSIONS AND

RECOMMENDATIONS

Introduction

Purpose of the study 100

Review of Literature 100

Methodology

Results of the Study 103

Discussion of the Results 108

Conclusions and Implications

Recommendations

Appendix

A. CROSS TABULATIONS

B. CORRESPONDENCE

C. QUESTIONNAIRE

VITA. 


\section{LIST OF FIGURES}

1. World Cumulative Adult HIV Infections by Mode of Transmission $\ldots \ldots \ldots 15$

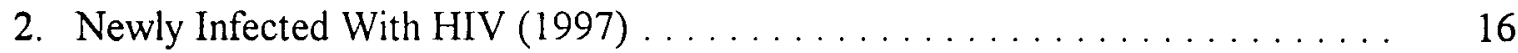

3. Estimated Number of Living With AIDS (1997) .............. 17

4. HIV Transmission Modes in Ethiopia (1996) ................... 19

5. Ethiopia: Age and Sex Distribution of Reported AIDS Cases (1996-95) . . . . 21 


\section{LIST OF TABLES}

1. Demographic Characteristics of Academy Students Responding ....... 35

2. HIV/AIDS-Related Belief Responses Among Academy Students $\ldots \ldots \ldots 37$

3. HIV/AIDS-Related Knowledge Responses Among Academy Students .... 39

4. HIV/AIDS-Related Behavior Responses Among Academy Students ...... 43

5. Chi-Square Results of HIV/AIDS-Related Beliefs Responses Among Academy Students in Relation to Grade $\ldots \ldots \ldots \ldots \ldots \ldots \ldots .46$

6. Chi-Square Results of HIV/AIDS-Related Knowledge Responses Among Academy Students in Relation to Grade ..................

7. Chi-Square Results of HIV/AIDS-Related Behavior Responses Among Academy Students in Relation to Grade . . . . . . . . . . . . . . . . . . .

8. Chi-Square Results of HIV/AIDS-Related Beliefs Responses Among Academy Students in Relation to Age ....................

9. Chi-Square Results of HIV/AIDS-Related Knowledge Responses Among Academy Students in Relation to Age ....................

10. Chi-Square Results of HIV/AIDS-Related Behavior Responses Among Academy Students in Relation to Age ....................

11. Chi-Square Results of HIV/AIDS-Related Beliefs Responses Among Academy Students in Relation to Gender . . . . . . . . . . . . . . . .

12. Chi-Square Results of HIV/AIDS-Related Knowledge Responses Among Academy Students in Relation to Gender

13. Chi-Square Results of HIV/AIDS-Related Behavior Responses Among

Academy Students in Relation to Gender

14. Chi-Square Results of HIV/AIDS-Related Beliefs Responses Among

Academy Students in Relation to Religious Affiliation ... 
15. Chi-Square Results of HIV/AIDS-Related Knowledge Responses Among Academy Students in Relation to Religious Affiliation . . . . . . . . . . .

16. Chi-Square Results of HIV/AIDS-Related Behavior Responses Among Academy Students in Rélation to Religious Affiliation .............

17. Chi-Square Results of HIV/AIDS-Related Beliefs Responses Among Academy Students in Relation to Length of Attendance at SDA Schools

18. Chi-Square Results of HIV/AIDS-Related Knowledge Responses Among Academy Students in Relation to Length of Attendance at SDA Schools

19. Chi-Square Results of HIV/AIDS-Related Behavior Responses Among Academy Students in Relation to Length of Attendance at SDA Schools

20. Chi-Square Results of HIV/AIDS-Related Behavior Responses Among Academy Students in Relation to the Extent to Which Students Talk to Their Parents or Other Adults 89

21. Summary of Research Questions 4 through 19 91

22. Percentage of HIV/AIDS-Related Belief by Grade 117

23. Percentage of HIV/AIDS-Related Knowledge by Grade

24. Percentage of HIV/AIDS-Related Sexual Behavior by Grade 123

25. Percentage of HIV/AIDS-Related Belief by Age $\ldots \ldots \ldots \ldots \ldots \ldots$

26. Percentage of HIV/AIDS-Related Knowledge by Age 126

27. Percentage of HIV/AIDS-Related Sexual Behavior by Age $\ldots \ldots \ldots \ldots$ 130

28. Percentage of HIV/AIDS-Related Belief by Gender 131

29. Percentage of HIV/AIDS-Related Knowledge by Gender

30. Percentage of HIV/AIDS-Related Sexual Behavior by Gender 137

31. Percentage of HIV/AIDS-Related Belief by Religious Affiliation 138

32. Percentage of HIV/AIDS-Related Knowledge by Religious Affiliation 140 
33. Percentage of HIV/AIDS-Related Sexual Behavior by Religious Affiliation . .

34. Percentage of HIV/AIDS-Related Belief by Length of Attendance at SDA Schools

35. Percentage of HIV/AIDS-Related Knowledge by Length of Attendance at SDA Schools

36. Percentage of HIV/AIDS-Related Sexual Behavior by Length of Attendance at SDA Schools

37. Percentage of HIV/AIDS-Related Sexual Behavior Responses by Extent to Which Students Talk to Their Parents 


\section{ACKNOWLEDGMENTS}

I want to thank all of those who faithfully supported me throughout this study. Without their encouragement this thesis would not have been possible.

I am extremely grateful to Dr. Jimmy Kijai for his expertise, guidance, patience, for being the chairperson of my thesis committee and for being a great friend. Working on a thesis through e-mail was not easy, but he faithfully kept encouraging me and working closely with me to see me through to the end. Jimmy, I owe you a nice fishing trip! Thank you so much!

Dr. Gary Brendel and Dr. Rudi Maier, thank you for your insights into the development of the extended campus program, your faithful encouragement and positive attitudes to see me through this thesis, and for your sincere friendship. To Dr. Duane McBride, thanks for your willingness to serve in my thesis committee.

To Bonnie Proctor for the hours you spent in the editing of the final manuscript; Dr. Danilo Poblete for your guidance, support and assistance; Mr. Abebe Disasa for your assistance in obtaining permission and support to do the research in Ethiopia; Mr. Alaka Anota, Mr.Addise Ansebo, Mr. Mismaku Yazachew for your support and permission to do the research at each of your academies, I salute you.

Without the constant support of my husband, Andrew, I would not have succeeded. To my children Andrew, Joshua, Melissa, Kristine and Jeremiah, I am very grateful. Your patience and willingness to spend many nights and weekends without mom 
was a real sacrifice. A special thanks to my son Andrew for the hours he spent teaching me how to use the computer.

Above all, I want to thank God for this opportunity, for giving me the mental capacity to actually do this, and sustaining my health during the long hours that it took to finish this project. Thanks Lord! 


\section{CHAPTER 1}

\section{INTRODUCTION}

\section{Background}

Human Immunodeficiency Virus, known as HIV, is the causative agent for the Acquired Immunodeficiency Syndrome, known as AIDS. AIDS has become the most serious health problem in many countries all around the world. The United Nations Program for AIDS (UNAIDS) and the World Health Organization (WHO) estimate that over 30 million people were living with HIV infection at the end of 1997. That is 1 in every 100 adults between the ages of 15 to 49 worldwide. AIDS cases have been reported in nearly every country of the world, with an estimated total of 11.7 million AIDS deaths among adults and children worldwide since the 1970s when the disease was first discovered (United Nations AIDS [UNAIDS], 1997). At the end of the 12th World AIDS Conference held in Geneva, Switzerland, on Friday, July 10, 1998, speakers had issued a call to arms, saying that AIDS will strike 40 million people by the year 2000 and the battle against the pandemic is not nearly finished (" $12^{\text {th }}$ World AIDS Conference," 1998).

Sub-Saharan Africa is the region with the fastest-moving AIDS epidemic: It is estimated that 20.8 million adults and children in Sub-Saharan Africa are living with HIV/AIDS, followed by South and Southeast Asia, with over 6.0 million adults and children infected (UNAIDS, 1997). More than $90 \%$ of all HIV-infected people live in 
developing nations and more than two thirds of the globe's HIV-infected population and about $90 \%$ of all infected children live in Sub-Sahara Africa (Mann \& Tarantola, 1998). Ethiopia, the second most populous country in Africa, had an estimated 55-60 million inhabitants in 1995. In 1996 it was estimated that about 1.7 million people were infected with HIV in Ethiopia. This is considered to be a rudimentary estimate, however, since surveillance and reporting mechanisms are few in the country (AIDS in Ethiopia, 1996).

Adolescents, as a group, have only recently been identified as being a high-risk group for HIV infection. Some of the contributing factors to this include adolescents' high rates of sexual experimentation, increased anatomical and physiological susceptibility, and reluctance to condom usage (Williams \& Ponton, 1992). In Ethiopia, over $80 \%$ of AIDS cases are reported in the 20-to-49-year age group. And the proportion of male and female cases is about equal. This is attributed to the fact that most HIV infection is acquired through sexual contact in Ethiopia. For females, the peak age for AIDS cases has been identified between 20-29 years of age and for males 20-39. Since AIDS cases usually result from HIV infection acquired 3-10 years earlier, this means that the peak ages when the infection was acquired are between 15 and 24 years for females and 15 to 34 years for males. The absence of HIV infection in children between the ages of 5-14 demonstrates the "Window of Hope." This is the age group when, if taught how to protect themselves from HIV infection before they have become sexually active, they can remain HIV-free (AIDS in Ethiopia, 1996). It has been stated that increased sexual activity among the youth is a major contributing factor to the spread of HIV/AIDS in Ethiopia (Ethiopia Country Health Profile, 1996). 
In view of the lack of an immediate forthcoming immunization or cure, behavior change is the recognizable means for curbing the spread of HIV. In order to affect the primary mode of transmission, people have to avoid risky sexual behavior (Gebre, 1990; Khodakevich, 1990; Morbidity and Mortality Weekly Report, 1993).

Various influential factors mold a young person's value system. Family/adult communication, education, and religious orientation are primary factors. In a national longitudinal study published by the Journal of American Medical Association in 1997, two factors that were noted in influencing adolescents delaying their sexual debut were high levels of parent-family connectedness and attendance at a parochial school (Resnick et al., 1997).

Adolescents cannot avoid choosing values. The values they choose will shape their lives. "The type of family in which young people are raised is still the greatest indicator of the values they will hold" ("Values: Will Our Children Carry the Torch?" 1991 , p. 28). Being a positive model can be the greatest contribution that a leader, teacher, or parent can make to an adolescent ("Values," 1991). However, it has been said that the best approach to teaching adolescents morality is for parents to communicate (Otis, 1998)

According to the Morbidity and Mortality Weekly Report (1993), the first concept in the prevention and control of sexually transmitted diseases (STDs), of which AIDS is one, is based on education of those at risk. An educational program which is targeting adolescents must take into consideration important factors such as (1) knowledge, (2) attitudes towards the risk, (3) sexual behaviors, and (4) attitudes towards a friend infected with the virus. This will call for health education and modification of 
sexual behavior at a crucial developmental period when the relevant knowledge, attitudes, and behaviors are the issues when this psychosocial development is being worked out individually (Williams, 1992). Health education programs need to be designed to directly impact the antecedents of the behavior. These must be determined and instituted before the damaging behavior occurs (Dryfoos, 1990).

The third influential factor in influencing behavior change is religion. Religion plays an important role in the life of Ethiopians. Fifty-four percent of the population are Orthodox Christian, 33\% Moslem, $6 \%$ Protestant, $1 \%$ Catholic, and only $6 \%$ are animist or other affiliation (Ethiopia Country Health Profile, 1996). It is therefore important to assess the relationship of HIV/AIDS infection to religious affiliation and/or attendance in a religious institution. It must also be remembered that cultural taboos and restrictions are adhered to in many settings, and adults as well as some adolescents feel it is not acceptable to discuss sexual matters even in a religious context.

Of the $54 \%$ of Orthodox Christians in Ethiopia, 114,018 people are of the Seventh-day Adventist faith (SDA Yearbook, 1997). The Seventh-day Adventist church has taken the stand that youth are growing up in an era of moral laxity, and need to be taught biblical principles regarding sexuality. The SDA church maintains a strong belief in abstinence from sex before and outside of marriage (SDA Church Manual, 1995). In The Seventh-day Adventist Church and the AIDS Epidemic-Guidelines (1996) the following guidelines for the SDA church are noted:

1. Engage in efforts to reduce the risk of individuals acquiring AIDS.

2. Develop and maintain AIDS education programs. 
3. Intentionally transmit Christian values to the next generation,

recognizing that individual sexual values are established in youth.

In just 25 years online pornography, no-fault divorce, virulent new strains of sexually transmitted disease and same-sex relationships have become commonplace. The new values include tolerance and acceptance without judgement. The mentality that anything is permissible has permeated our schools and even seeped into some of our churches. (Otis, 1998, p. 10)

For SDA educational institutions, one goal must therefore be to ascertain the impact that AIDS-related belief, knowledge, and demographic variables have on the sexual behavior of students attending SDA boarding schools in Ethiopia in an effort to reach the youth with vital information that can help them foster Christian values that will in turn assist them in avoiding AIDS high-risk behaviors.

There are three SDA boarding schools in Ethiopia: Akaki Adventist School, Wollega Adventist Academy, and Ethiopia Adventist College Academy. All three institutions have participated in this study in an effort to gain feedback that will assist administrators and teachers in the development, integration, and implementation of essential Christian values to adolescents in the SDA boarding schools in Ethiopia.

\section{Purpose of the Study}

The purpose of this study was to investigate the beliefs and knowledge about AIDS/HIV and sexual behavior of students attending three Seventh-day Adventist secondary schools in Ethiopia. Specifically, this study was designed to answer the following research questions:

1. What are the students' beliefs towards HIV/AIDS?

2. What is their levels of knowledge regarding HIV/AIDS? 
3. What are the sexual behaviors in relation to HIV/AIDS among these

students?

4. Is there a relationship between grade levels and beliefs towards HIV/AIDS?

5. Is there a relationship between grade levels and knowledge level regarding HIV/AIDS?

6. Is there a relationship between grade levels and sexual behavior in relation to HIV/AIDS?

7. Is there a relationship between age and beliefs towards HIV/AIDS?

8. Is there a relationship between age and knowledge level regarding HIV/AIDS?

9. Is there a relationship between age and sexual behavior in relation to HIV/AIDS?

10. Is there a relationship between gender and beliefs towards HIV/AIDS?

11. Is there a relationship between gender and knowledge level in relation to HIV/AIDS?

12. Is there a relationship between gender and sexual behavior in relation to HIV/AIDS?

13. Is there a relationship between Seventh-day Adventist religious affiliation and beliefs towards HIV/AIDS?

14. Is there a relationship between Seventh-day Adventist religious affiliation and knowledge level in relation to HIV/AIDS?

15. Is there a relationship between Seventh-day Adventist religious affiliation and sexual behavior in relation to HIV/AIDS? 
16. Is there a relationship between years of attendance at Seventh-day Adventist schools and beliefs towards HIV/AIDS?

17. Is there a relationship between years of attendance at Seventh-day Adventist schools and knowledge level in relation to HIV/AIDS?

18. Is there a relationship between years of attendance at Seventh-day Adventist schools and sexual behavior in relation to HIV/AIDS?

19. Is there a relationship between the extent to which students talk to their parents or another adult and sexual behavior in relation to HIV/AIDS?

\section{Significance of the Study}

In an interview on February 2, 1998, with Mr. Abebe Disasa, Education Director of the Ethiopian Mission of Seventh-day Adventists, it was noted that there have been no studies, surveys, or ongoing HIV/AIDS programs in any of the Adventist schools in the country. As Mr. Disasa wrote in his letter of permission, "this study is the first one of its kind in our schools" (Personal communication, 1998). Currently the subject of HIV/AIDS is discussed in the schools merely as another topic related to sexually transmitted diseases (STDs) in health or biology classes. This study is therefore significant in that it is the first to be conducted within SDA schools in the country of Ethiopia. There were 1,280 students registered when the survey was given, and 1,140 students were in attendance on the specific days and participated in the study. Students were requested to anonymously fill out a 38-item, multiple-choice questionnaire which contained selected questions on the students' beliefs, knowledge, and sexual behavior regarding HIV/AIDS.

Evidence is clear at this time that the number of people becoming infected with HIV/AIDS will continue to increase, there is no immediate hope of vaccination against 
HIV/AIDS in the near future, and there is no current cure for HIV/AIDS. With this in mind, an effective means of stopping and/or decreasing the spread of HIV/AIDS is through value and moral behavior change. This behavior change can be facilitated through knowledge. Dryfoos (1990) noted, however, that surveys have shown that adolescents know a lot about AIDS, but they have not changed their behavior.

Knowledge in conjunction with value and moral change can enable adolescents to make an educated decision for behavior change. Educational institutions are a prime medium in which knowledge can be assimilated and presented to adolescents in an ongoing process and format. Keeping in line with the guidelines for the SDA church, Adventist educational institutions should be targeted for research. This survey can also provide a baseline for further studies on health education programs aimed specifically toward HIV/AIDS, their subsequent development, and recommendations.

\section{Limitations of the Study}

This study was designed to assess the beliefs, knowledge level, and sexual behaviors regarding HIV/AIDS in adolescents attending three Seventh-day Adventist boarding schools in Ethiopia during the 1997-1998 academic school year. A large portion of the students attending the three secondary schools were not Seventh-day Adventists: Therefore the result of the study may not be representative of the beliefs, levels of knowledge, and sexual behaviors of Seventh-day Adventist secondary school students in Ethiopia. 


\section{CHAPTER II}

\section{REVIEW OF LITERATURE}

\section{Background}

In 1981, a strange disease was being seen in the United States. Doctors did not know what caused it, where it came from, or how to treat it. It was killing people and it was spreading. By 1986, 15,345 people had already died, 1,200 were dying, and 3,000 more were feeling unwell. Strange infections were being seen, all with classic symptoms that related to a weakening of the body's natural defenses. The disease was called AIDSAcquired Immune Deficiency Syndrome (Dixon, 1994). In 1985 in France and the United States it was discovered that AIDS was caused by the human T-cell leukemia virus (HTLV), and in May 1986 it was then called what is now known as the human immunodeficiency virus (HIV) (LaPierre, 1991).

AIDS and HIV are not the same. A person can live with the HIV for several years before being diagnosed as having AIDS. During the time period when a person is asymptomatic he/she is still a carrier and can pass the virus on. AIDS is not an isolated disease in itself, It is the end stage of infection with HIV. AIDS is a serious, debilitating, and eventually fatal disease. Acute infection can occur within 1 to 8 weeks after a person has become infected with HIV. However, it is known that when HIV enters a person's bloodstream, the person will not always become infected with the virus. If there are a large 
number of viral particles introduced, if the resistance of the host is low, if the defense systems respond slowly, then HIV infection will occur. Also, the more frequent the exposure to the virus or the larger the amount of blood involved, the greater the chance of infection. If a person has been injected with HIV-infected blood from a blood transfusion, AIDS is almost certain to develop because of the large number of viral particles injected which could overwhelm almost any person's defense system (Wood \& Dietrich, 1990). In addition, since the likelihood of HIV/transmission through blood depends on the amount of the virus in the blood, the risk of getting HIV from a contaminated needle, syringe, or skin-piercing instrument is much lower than with a blood transfusion. It was further noted that less than $3-5 \%$ of all HIV/AIDS cases in the world are transmitted through blood transfusions (Negerie, 1998).

As was stated previously, AIDS is not a disease in itself. The " $\mathrm{S}$ " in the acronym denotes the fact that it is a syndrome of what could be called complications or results. Persons with AIDS are profoundly immunosuppressed and have possibly lived with HIV for several years before AIDS has developed. To be diagnosed as having AIDS a person must be infected with HIV, have clinical manifestations to denote cellular immunodeficiency, and have no other reason to be cellularly immunodeficient (Ignatavicius, Workman, \& Mishler, 1995).

The time frame from the initial HIV infection to developing AIDS ranges from 18 months to more than 10 years. However, the average time from infection with HIV to the development of AIDS is about 7 to 8 years. The wide range differs depending on the way in which the virus was acquired, nutritional status, presence of other sexually transmitted diseases (STDs), pregnancy, and stress. 
AIDS is a preventable disease. It can be prevented by not participating in any type of sexual behavior before marriage and then maintaining a faithful, monogamous, heterosexual relationship with a non-infected partner after marriage. It can also be prevented by not participating in the use of illicit intravenous drug use, and ascertaining the sterility of needles and equipment used in medical care. It can further be prevented by not receiving a blood transfusion from untested and/or unknown sources.

\section{Etiology}

Acquired Immunodeficiency Syndrome is caused by the extreme suppression of the body's immune system from the human immunodeficiency virus. In 1994, Dixon documented in The Truth About AIDS that "there are probably at least six HIV strains already" (p. 64). There are two sub-types of HIV: HIV-1, having five major variants and found primarily in the Western Hemisphere, Europe, and Asia, and HIV-2, having one major variant, which is endemic to West Africa. HIV-1 is spread primarily through intravenous drug users and homosexual men. HIV-2 is spread almost entirely through heterosexual relationships. Both subtypes can cause AIDS (Ignatavicius et al., 1995; Dixon, 1994).

HIV is transmitted by three main modes: (1) sexually-exchange of HIVinfected body fluids such as semen, vaginal secretions, or blood during sexual intercourse, (2) blood-receiving blood transfusions intravenously, sharing of syringes and needles, using sharp, non-sterilized instruments, organ transplants from HIV-infected people, and (3) vertical-from HIV-infected mother to her unborn child during delivery, or after, in breast milk. HIV is not transmitted through casual contact such as holding hands, kissing, 
touching, or sharing the same room. Neither is it transmitted through insect bites such as mosquitoes or bed bugs (Kariuki, 1998). The HIV virus is also found in tears, saliva, sweat, urine, and feces but not in concentrations high enough to be considered infective. Direct body fluid contact must occur for infection to take place.

The HIV then quickly penetrates the white cells called CD4 cells in the body. The white cells are then "reprogrammed" after which there is often little or no trace of the virus at all. This status can last for 6 to 12 weeks, an incubation period, during which time the person is free of symptoms and antibody tests are negative. After the incubation period, many people develop a flu-like illness. During this time some white cells are dying, the virus is being released into the body, and then the body tries to make the correct antibodies to combat the virus. It is at this time that a person will begin to test positive for HIV. This process is called sero-conversion. The person has now converted to HIVpositive. His or her body will settle down for a while, and the person will feel completely well again. For months or even years the person will feel "well" all the while the disease is slowly progressing. The person will eventually develop what is known as the AIDS Related Complex or simply ARC. With ARC a person may have fever, diarrhea, fatigue, and/or weight loss of unknown origin, leukoplakia (white patches in the mouth), night sweats, lymphadenopathy, memory loss, confusion, seizures, personality changes, skin changes, pain, respiratory difficulties, and/or fungal infections. The final stage of the illness is what is called AIDS. Most of the symptoms and disorders that have arisen thus far can be treated with medication or the body has been able to fight them off for a period. It is during this stage that the body will succumb to infections that are not treatable, the person will begin to lose the fight for life, and death is the usual result (Dixon, 1994). 
The enzyme-linked immunosorben assay (ELISA) test is the most common method of testing for HIV. The ELISA test actually tests for the antibodies that the body produces in reaction to the infection and does not test for the presence of the HIV itself. ELISA tests are considered to be very accurate but occasionally need to be repeated. An ELISA test is ultra-sensitive and will pick up every person who has the HI virus. It is possible that it can also give a false-positive report by such things as recent influenza vaccination, hepatitis $B$ vaccinations, or malaria. Confirmation can be obtained by performing a Western Blot test, which is specific to HIV, or repeated ELISA testing can also be done (Dixon, 1994).

\section{International Scope}

"The HIV/AIDS pandemic is volatile, dynamic, increasingly complex in societal and geographic terms, and growing rapidly in scope and impact" (Mann \& Petitgirard, 1995, p. 103). According to an UNAIDS report (cited in Scientific American, 1998), the UNAIDS and WHO (1997) estimate that there were over 30 million people living with HIV infection at the end of 1997. It was further stated that in "1997 alone, there were almost six million people-close to 16,000 a day-that acquired HIV and about 2.3 million died from it" (Mann \& Tarantola, 1998, p. 82-83).

The greatest percentage of HIV infection (see Figure 1) in the world is spread through heterosexual activity, followed by homosexual practices, injection drug use, and blood. The international pandemic of AIDS/HIV infection is growing rapidly, especially in developing nations, where the vast majority of people live. According to Mann and Petitigirard (1995), "of global infections among adults to date, $71 \%$ have been hetero- 
sexually transmitted" and "globally, heterosexual transmission is responsible for approximately $90 \%$ of HIV infection among women, and with about $58 \%$ among men" (p. 103).

\section{National Scene}

More than $90 \%$ of all world-wide AIDS cases in 1997 were found in developing countries (see Figure 2). Of the developing countries (see Figure 3) SubSaharan Africa is the region with the fastest-moving AIDS epidemic and is now thought to have at least two-thirds (68\%) of the total world number of people infected with HIV (UNAIDS, 1997). This is an estimated 20.8 million people, which is up from the mid-1996 estimate of 13.3 million. Overall, the HIV prevalence is still rising with the exception of Uganda, where HIV appears to be declining (Kerkhoven, 1998). Heterosexual relationships are primarily responsible for almost all of the HIV/AIDS cases in Africa and are responsible for the subsequent new strain that has been discovered on this continent (Dixon, 1994).

As was stated about Africa by Patrick Dixon (1994):

Grandmothers are looking after their grandchildren because so many young men and women, the parents, have been wiped out by AIDS. Armies of troops in Central Africa are being depleted--not by rockets and machine guns, but by AIDS. Breadwinners for families and providers of the countries' wealth are missions. The educated elite living in the main towns and cities have often been the worst hit. In the country fields are uncultivated and cattle wander aimlessly. One journalist, visiting an African country recently, describes areas where whole families have been wiped out, plantations have gone back to bush and you can walk for miles without seeing anyone--a wasteland. I have met someone who claims to have satellite photographs of a country in Central Africa taken two years apart, showing not deforestation, but reforestation as the amount of farming falls. It is an effect attributed to AIDS--the country is not at war. In 1991 I was told my a trusted colleague that he thought it would be hard to find a family in the African city where he lived who was not attending an AIDS funeral on average once a month. Deaths had soared among young adults in the previous three years. In Africa they call it the 


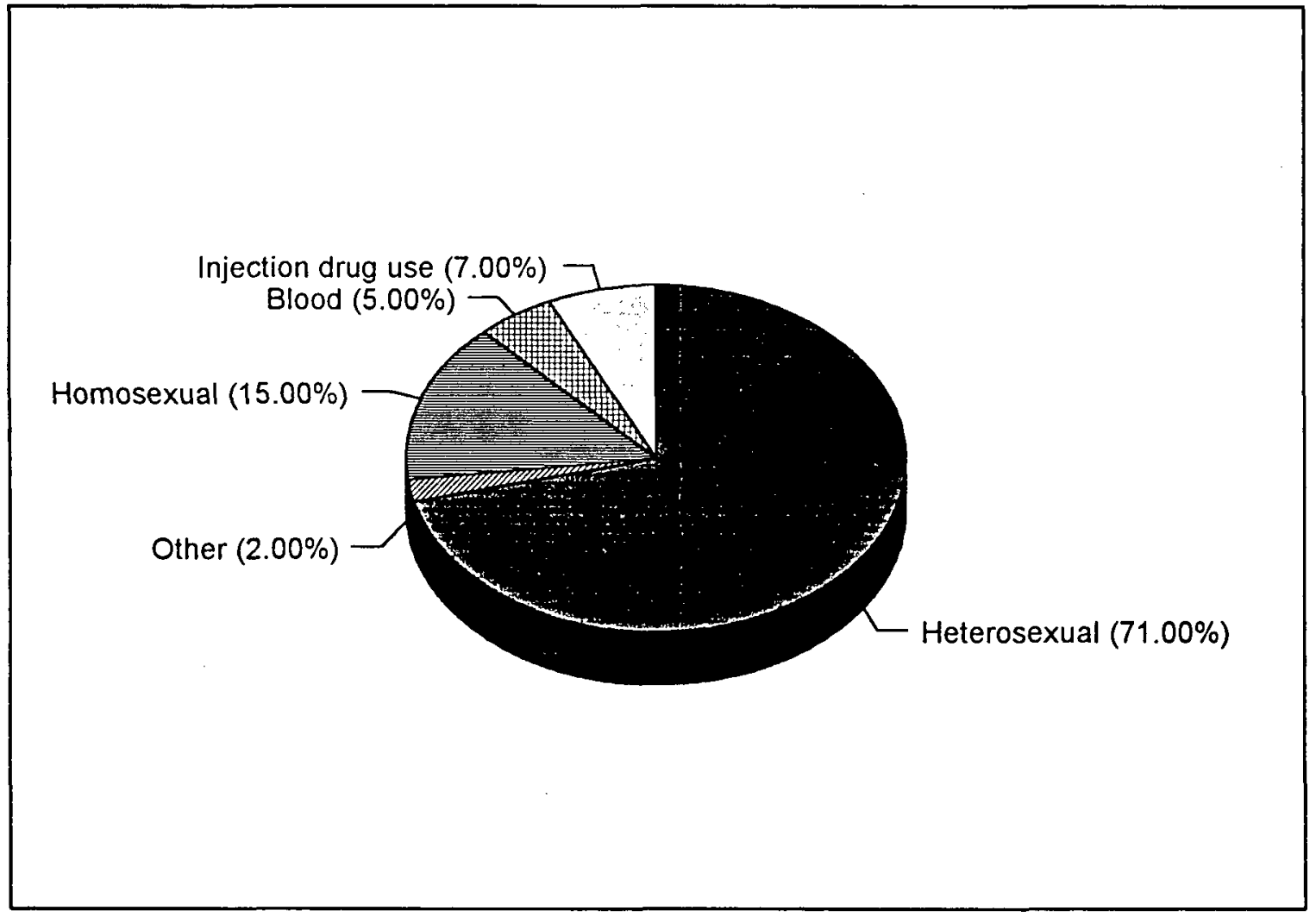

Figure 1. World cumulative adult HIV infections by mode of transmission. 


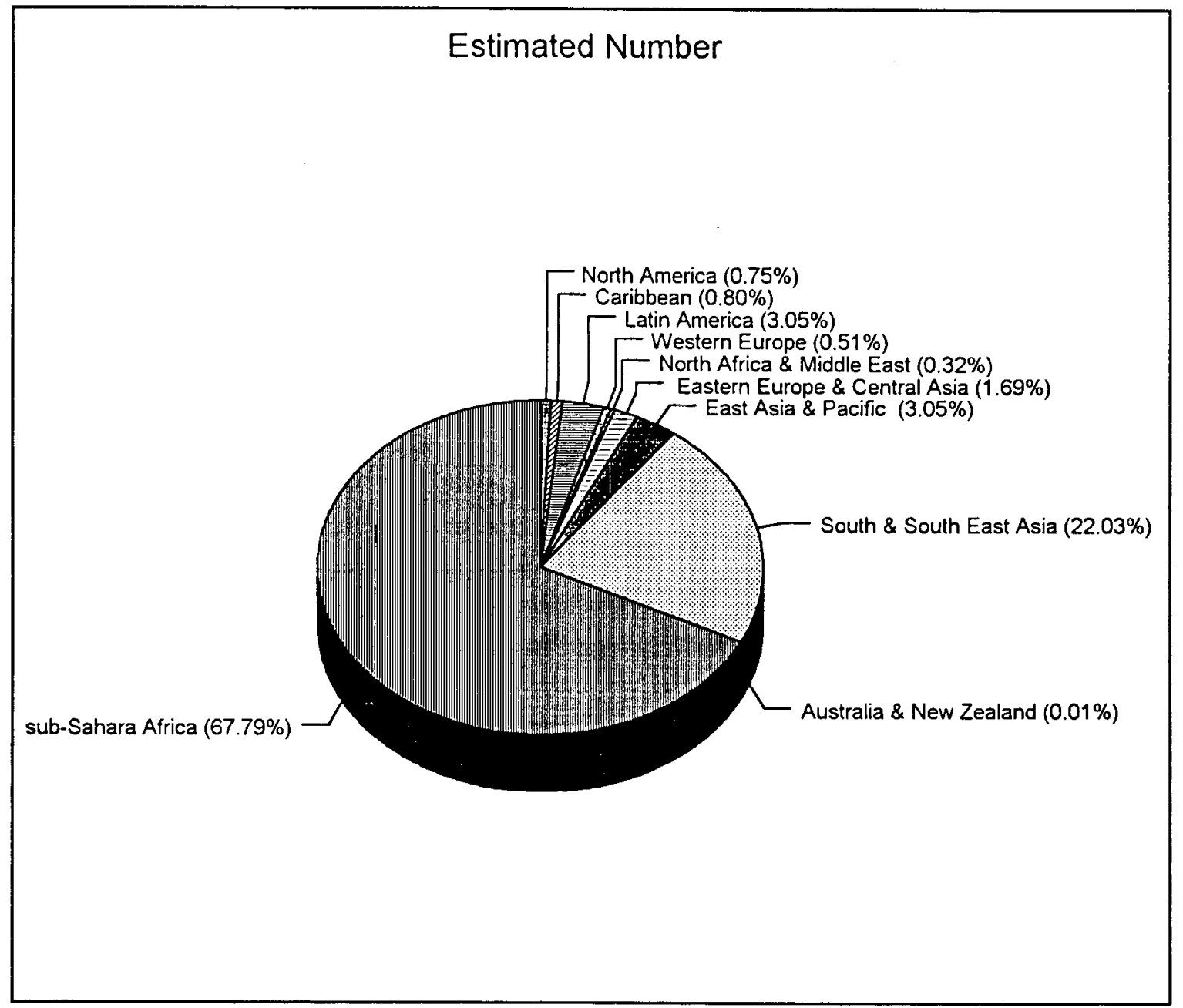

Figure 2. Newly infected with HIV in 1997. 


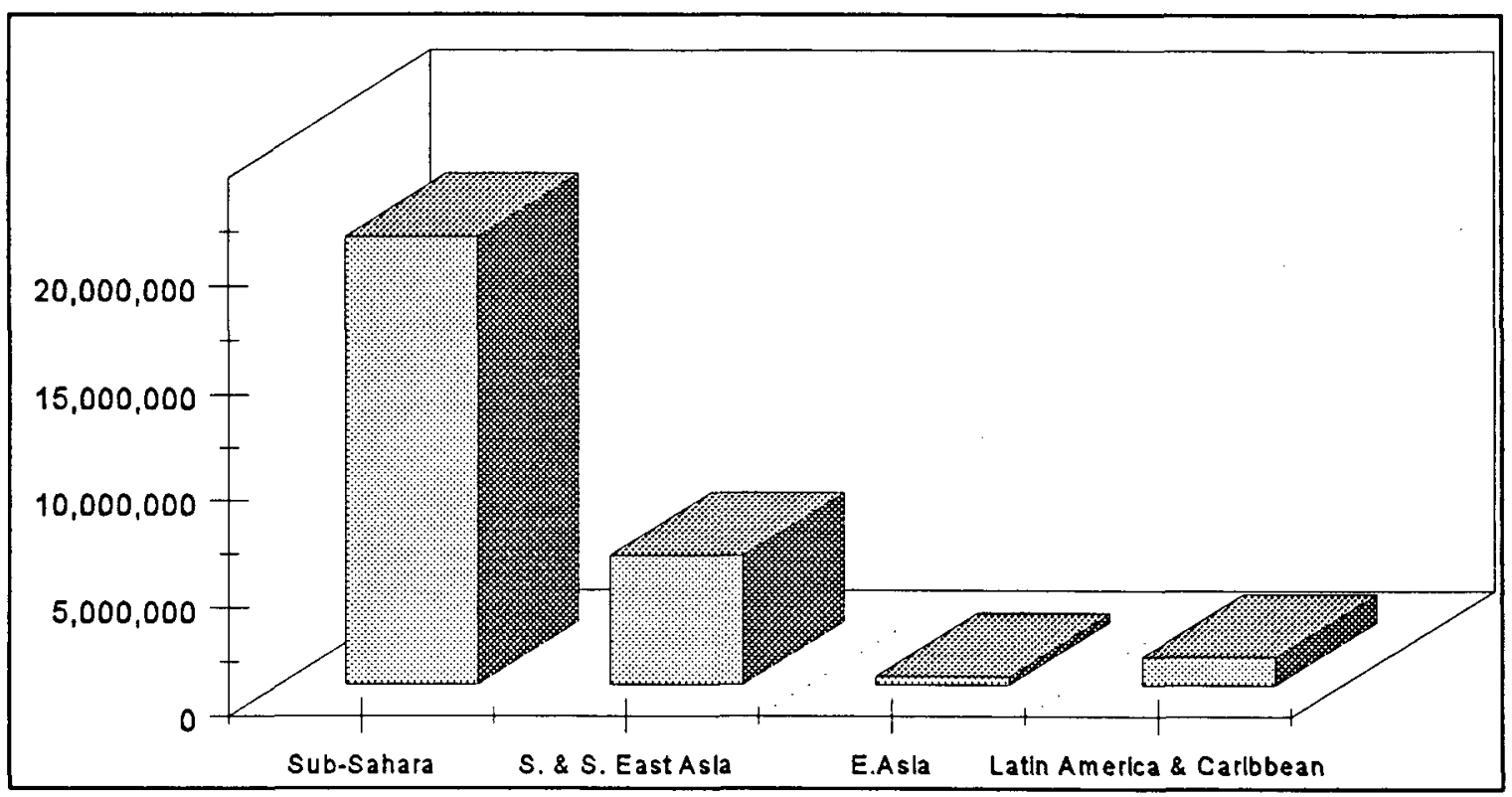

Figure 3. Estimated number living in developing nations with AIDS, 1997.

'slim' disease. Some Africans believe if you sleep with only fat women you are safe. To be fat is healthy. (p. 21)

\section{Ethiopian Scene}

Ethiopia, the second most populous country in Africa and located in the subSahara region, had an estimated 55-60 million inhabitants in 1995. The first AIDS case in Ethiopia was reported in February 1986. According to the Ethiopian Ministry of Health, it was estimated that by 1993 the adult HIV prevalence rate had increased to $3.2 \%$. By 1996 , it was estimated that this rate had already increased to $5.2 \%$. In urban areas it was felt that more than one out of every nine adults were probably infected by HIV (W/yohannes, 1996). It was estimated that in 1996 there were about 1.7 million people infected with HIV in Ethiopia, and the WHO estimated that for every 19 adults (of the total adult population), 1 is infected. This is considered to be a crude estimate, however, 
since surveillance and reporting mechanisms are few in the country (AIDS in Ethiopia, 1996).

The low rate of reporting in Ethiopia is a result of the following:

1. Some people never seek hospital care for AIDS.

2. Doctors may not choose to record the diagnosis of AIDS.

3. Those infected may die of other diseases before they are diagnosed.

4. Rural health services have a low capacity to test for HIV.

5. People have poor access to health care services.

Four mechanisms of HIV transmission are prevalent in Ethiopia: blood transfusion, illegal injections, perinatal transmission, and heterosexual activity. As can be seen in Figure 4, 87\% of new HIV infections are from heterosexual activity. Two factors have been cited that increase the risk of heterosexual infection dramatically: These are the presence of another sexually transmitted disease, such as gonorrhea or syphilis in either partner, and the prevalence of having a large number of sexual partners. The remaining $13 \%$ in order of prevalence are from perinatal transmission, blood transfusions, and lastly from injection, with a minute amount from what was listed as "unknown" causes. It was estimated that about $35 \%$ of babies born to infected mothers will be infected themselves. Most blood in Ethiopia is screened for HIV, thus a smaller percentage of HIV infections is as a result of blood transfusions. The last category is unsafe injections. Although proper health practice requires sterilization of needles or use of disposable needles and syringes, unsafe practices can result in the spread of HIV infection. (AIDS in Ethiopia, 1996). 


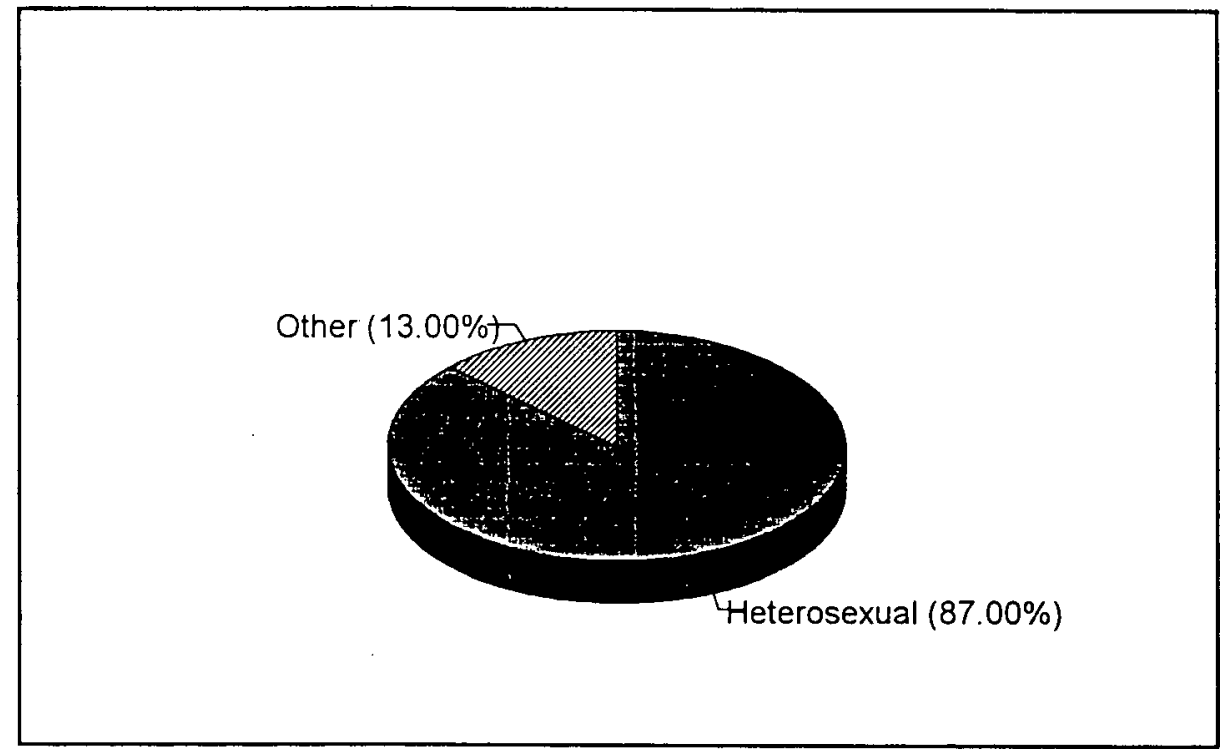

Figure 4. Estimated HIV transmission modes in Ethiopia for 1996. Note: The $13 \%$ of other denotes perinatal transmission, blood transfusion, and unsafe injection practices.

\section{Adolescent Scene}

In a study of the Ethiopian urban population (Mehret, 1995) it was found that $22 \%$ of adult males and $8 \%$ of women were sexually active with multiple sexual partners. In another study conducted at a senior high school in Addis Ababa, it was found that $53 \%$ of male students and $24 \%$ of female students were sexually active. In this study it was seen that $32.6 \%$ of the respondents could not answer half of the questions correctly. The overall average knowledge showed a correct response of slightly less than $50 \%$ of the questions. It was also noted that the respondents have almost the same level of knowledge irrespective of gender, grade, religious affiliation, or sexual experience (Gebre, 1990). 
A third study done at Gondar College of Medical Sciences in Ethiopia for the 1990-1991 school year reported that $49.5 \%$ of the boys and $18.3 \%$ of the girls had experienced sexual intercourse, with $19.6 \%$ being with a prostitute and $27.3 \%$ with a casual partner. The knowledge level was noted to be "adequate" and was comparable to that of other college and high-school students in Ethiopia (Teka, 1993). In a subsequent study done at the same college a few years later, it was reported that $32.9 \%$ of boys and $33.7 \%$ of girls have had 1 to 5 or more sexual partners (Petros, Belayneh, \& Mekonnen, 1997)

Out-of-school youth were interviewed in 1994 in Bahir Dar Town, Ethiopia. Of the interviewed youth, $59.3 \%$ were already sexually active with the mean age of sexual debut being 16.9 years, and the average number of sexual partners being 3.9. Some of the factors that were significantly related to knowledge, attitude, and practice were age, sex, and education level being those that had some high-school education. The primary source for learning about HIV/AIDS was the radio at $80.1 \%$. Almost three-fourths $(71.4 \%)$ were unable to identify more than one way in which HIV/AIDS was spread (Fantahun \& Chala, 1996).

The Epidemiology and AIDS Department of Ethiopia made a compilation of country-wide AIDS cases (see Table 5). Over $80 \%$ of AIDS cases were found in the 20to- 49 age group. This is the age group that is the most economically productive in the country, the time when education investments are being realized, and the age group that will most directly involve children since most people in this age group are raising children. AIDS Analysis Africa states that of the 30 million people who are living with AIDS, at least one-third are ages 10 to $24(1998 / 1999)$. This cohort accounts for 50 to $60 \%$ of 
those who become infected after infancy and of that number $85 \%$ are from the developing world. The peak age of HIV infection for females in Ethiopia is between 20-29 and for males 20-39. In comparison, it was noted that according to AIDS in Kenya (1998), about $75 \%$ of AIDS cases in Kenya are among the 20-45-year age group, with a male-to-female ratio of $1: 1$. This is indicative of the fact that AIDS in Kenya, like Ethiopia, is spread predominately through heterosexual transmission. Taking into consideration that there is an average 3-10-year incubation period, this would mean that peak ages for acquiring HIV infection are 15-24 for females and 15-34 for males. Virtually

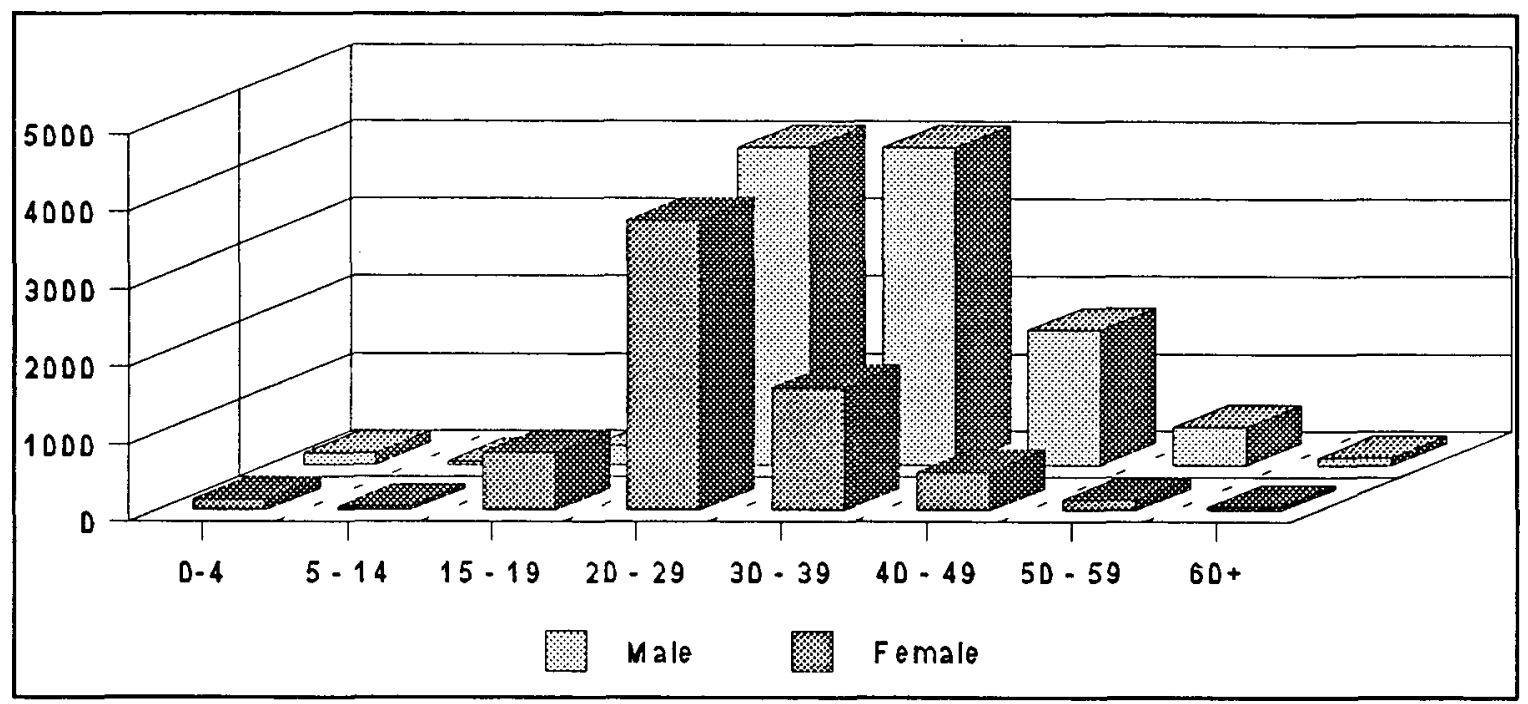

Figure 5. Ethiopia-age and sex distribution of reported AIDS cases (1986-1995).

no AIDS cases are found in the 5-14-year age group.

In a study conducted among adolescents from church-related high schools in Zaire (Tshimika, 1991), it was noted that $90.6 \%$ of boys and $76.4 \%$ of girls already had their first sexual experience. The average age for boys to have their sexual debut was 11 years of age and for girls 13; multiple sexual partners was a common practice. In this study it was noted that the majority of students knew the major ways in which AIDS is 
transmitted, e.g., sexual intercourse without using condoms, transfusion of HIV-infected blood, contaminated needles. However, many indicated that mosquitoes (63\%), saliva $(60 \%)$, sharing food (37\%), and by living in the same household (34.3\%) were also major ways to transmit AIDS. Moreover, $44.3 \%$ indicated that they would not want to be in the same classroom with someone infected with AIDS.

A recent study done in Kabale District, in Uganda, indicated that over $50 \%$ of students in primary Grade 7 were sexually active. Sexual activity was indicated in children as young as Grade 5 and 6 . In Kenya, studies show that about $85 \%$ of Kenyan teenagers have had sexual intercourse (Kariuki, 1998).

Research done in Kenya revealed that adolescents in higher grades were more sexually active than those in lower grades. Nearly $50 \%$ of the respondents had sexual intercourse while in primary school, and $71.1 \%$ had had sex by their first year in secondary school. It was also noted that parents rarely discuss sexual matters with their children (Kariuki, 1998).

In a research involving 600 young females in Malawi, in 1991 to 1992 four of every five girls had heard of AIDS, but only $14 \%$ believed that they had a "good or moderate" chance of getting it, while their perceived risk of contracting STDs was considerably higher. The grandmothers and older women told girls about menstruation, hygiene, and illness but most girls reported learning about sex from their peers (Kariuki, 1998).

About half of the world's population is below the age of 25 , and one-third are between the ages of 10 and 24 (Johnston, 1997). It was noted that up to $60 \%$ of all new HIV infections are among the 15-24 year olds (Johnston, 1997). Everyday, 7000 people 
ages 10-24 world wide acquire the HIV or 2.6 million every year (AIDS Analysis Africa, 1998/1999). Taking into consideration age and sex prevalence rates, it can be seen that adolescents should be targeted before they begin taking risks as it is easier to prevent a risk-taking habit from forming, than it is to change it (Dixon, 1994).

Youth need to know the facts about HIV/AIDS and need room to think how they will respond. Education is, relatively speaking, easy. Behavior change is very hard. Smoking kills hundreds of thousands of people each year, numbers which diminish the AIDS problem, yet campaigns in public health have taken years to begin to make a change. Sexual drive is stronger than intravenous drug use. This was seen in a study where only $14 \%$ of New York drug users changed sexual behavior while $59 \%$ used clean needles (Dixon, 1994). Parent-child communication will help children improve their decision-making skills (Dryfoos, 1990). In Ethiopia, Abeba, a 19-year-old girl, gave birth to her first child at age 15 . When she became pregnant she did not even realize it. Abeba said that she is no longer naive about sexual matters, and even though she still does not talk openly with her parents about sexual matters, she does talk regularly with her friends (Endris, 1993).

Dr. Anthony Evans (1992) noted that surveys show peers have replaced parents as the number one model for shaping behavior and values. Taking this into consideration, young people must be given sex education in a responsible, Christian context that will enable them to make positive moral choices to govern their life and empower them to be a positive mentor to their peers.

There has been a fear that sexual education in the school will lead to earlier or increased sexual activity. The WHO requested a review of 35 international studies. It 
was found that sex education can actually result in a delay in the onset of the first sexual intercourse experience and lead to more frequent use of condoms, rather than promoting sex as some have believed (Grunseit \& Kippax, 1993). It was also noted in Network, Family Health International that there is ample evidence from evaluation studies that indicate that sex and AIDS education may lead to safer sex practices and does not promote earlier or increased sexual activity (October, 1993). True, these statements do not say that sex education in schools will instill more positive moral values, but they do state that sex education does not promote sex.

In the developing countries, many students do not continue education beyond primary school. These children are very vulnerable to HIV infection. Remembering that there are virtually no HIV/AIDS cases in the 5-14 age group, it can be seen why this period has been termed "The Window of Hope." This is the time when children and youth need to develop moral values. It is the period when children and youth must learn how to choose and distinguish right from wrong. This is the area of hope for the future of our society, of our world.

In Uganda in the mid-1980s, Ugandan officials recognized the danger of AIDS and began a large-scale education program for secondary schools. During the time of the program, 4,510 youth, ages $15-24$ were surveyed. Results revealed that students were learning the information regarding HIV, but the increase in knowledge was not changing their sexual behavior. UNICEF then began Safeguard Youth from AIDS, or SYFA, in Uganda. SYFA is focusing on children ages 5-14, "The Window of Hope" period (Network, Family Health International, 1993).

Most people who advocate sex education in the school usually acquiesce that 
parents and/or churches could do a better job. However, a devastating realization has been made that parents and churches are not doing a better job. Often they are doing nothing at all. Many youth are learning about sex from pornography, and parents often feel intimidated about it. Some parents only pass on their limited misinformation and few churches offer any sex-education program let alone a comprehensive one (Stafford, 1993).

\section{Summary of Literature Review}

This literature review reveals that some studies have been done on adolescent knowledge, belief, and behaviors in regard to HIV/AIDS in Africa. It has been noted that few studies have been done in Ethiopia, and access to studies that have been done is not easy.

It has been noted that the vast majority of students do have some knowledge in regard to HIV/AIDS and that this knowledge has come from sources outside of the home or church. Regardless of their knowledge of HIV/AIDS, it was seen that many young people are sexually active and have their sexual debut at very young ages.

There have been no studies done in Seventh-day Adventist boarding schools in Ethiopia in the past. Currently, there is no structured program for sex education in the curriculum, and it is but mentioned as a part of the biology class curriculum. Sex education in the school system is not the ideal, but in the absence of positive and/or any parental support, it is the mode that at the present time can be an effective informationproviding medium. Students can be encouraged and provided with techniques in which they can better learn to communicate with their parents or other responsible adults. The 
goal of AIDS education should be to "facilitate and sustain responsible behavior for continued HIV prevention ... and should be based on culturally acceptable moral values and be integrated into ongoing school programs" (Sessional Paper No. 4 of 1997 on AIDS in Kenya, 1997). 


\section{CHAPTER III}

\section{METHODOLOGY}

\section{Purpose}

The purpose of this study was to determine the beliefs and level of knowledge about HIV/AIDS and sexual behavior of students attending three Seventh-day Adventist secondary schools in Ethiopia. This study also examined how certain demographic characteristics were related to the students' beliefs, knowledge level, and sexual behavior.

\section{Research Design}

The objective of the study was to collect information on beliefs, knowledge, and sexual behavior of academy students attending Seventh-day Adventist boarding schools in Ethiopia. The survey consisted of a 38-question, multiple-choice-answer questionnaire. This study was descriptive research to assess the dependent variables of HIV/AIDS- related beliefs, knowledge, and selected sexual behavioral practices that could predispose an adolescent to HIV infection.

\section{Population}

The subjects involved in the survey were students in Grades 9-12, enrolled in Seventh-day Adventist boarding academies in the second semester of 1998 in Ethiopia. 
Based on information provided by the director of education and the three individual academy principals, there was a total of 1,280 students registered in all three academies.

Of these, 1,144 students were present and all were requested to complete the survey, yielding a $89.375 \%$ response rate of total enrollment. All students present on the day of the survey filled out a questionnaire.

The survey was hand-carried to all three boarding academies. Students were told that their participation was voluntary and that their responses would be anonymous.

\section{Instrumentation}

The AIDS Survey for Students was the instrumentation used for data collection in this study. Originating in 1987, it was developed to assist 24 state and local departments of education in assessing HIV-related beliefs, knowledge, and behaviors among high-school students in the Unites States (Kann, Nelson, Jones, \& Kolbe, 1989).

This instrument was selected because of the direct relationship to my discussion of HIV/AIDS-related beliefs, knowledge, and sexual behavior of students attending Seventh-day Adventist boarding schools in Ethiopia. The construct, validity, and reliability had previously been examined by factor analysis investigation (Balsley, 1994).

For the purpose of this study, certain items from the original survey were deleted because they were deemed inappropriate. For example, the question about the use of public toilet was removed as this is not applicable in the country context. Four questions regarding intravenous drug usage were omitted based on the information provided by the Epidemiology and AIDS Department, Ministry of Health 1996, where 
intravenous drug usage is not considered a cause of the spread of HIV/AIDS in Ethiopia, whereas multiple-partner sexual contact ( $87 \%)$ is listed as the number one cause, about $25 \%$ from perinatal transmission, and a very small number due to blood transfusions and injections. The purpose of this study, therefore, was to focus on the main cause of HIV/AIDS in Ethiopia: sexual behavior.

\section{Survey Administration}

The survey was administered to $9^{\text {th }}$ - through $12^{\text {thr }}$ grade students attending the three Seventh-day Adventist boarding schools in Ethiopia. All students present on the day of the survey were asked to complete the survey.

Permission to conduct the survey in the academies was obtained from $\mathrm{Mr}$. Abebe Disasa, Education Director of the Ethiopia Union Mission of Seventh-day Adventists. Mr. Disasa then sent a letter introducing me and soliciting the cooperation of the principals from each of the individual academies. Permission and cooperation was then sought and granted from each of the principals. Each principal then received a letter of self-introduction and a brief explanation as to the purpose of the research. The principals were then contacted for clarification and approval of proposed time frame for presentation of the survey. Letters of permission were obtained from each principal granting permission for the survey to be administered in his school.

In the Ethiopian educational system, the Grade 12 students complete their structured education and leave the school near the end of March of each year. Because of the vast geographical expanse between schools and the time frame constraint, I requested the assistance of Mr. Samson Lemma, elementary school teacher for Overseas Elementary 
School, to administer the survey at Wollega Adventist Academy. Mr. Lemma was given instruction on the importance of the survey, administration procedure, and participant assurance of confidentiality of the survey.

On March 16, 1998, the questionnaire was class administered at Ethiopian Adventist College Academy to Grade 9 and 11 students, in their individual classrooms, one class period following the other. Grade 12 students were given the survey in the library. On March 17, 1998, Grade 10 students received the questionnaire. Before the questionnaires were handed out, students were requested to space themselves around the room, were reminded to not put their name on the paper, and to place completed questionnaires face down on a specified file at the front of the classroom. The average time to fill out the questionnaire was 20-25 minutes.

On March 19, 1998, the survey was taken to Akaki Adventist Academy. Mr. Addise Ansebo, principal, had previously selected specific teachers to hand out the questionnaires to students. Grade 9-11 students participated in the survey on this date, whereas Grade 12 students took the survey on March 23, 1998, when they returned to campus. Before the survey was handed out, students were requested to space themselves around the room, were reminded to not put their name on the paper, and to place completed questionnaires in large envelopes at the front of the classroom. The average time to fill out the questionnaire was 20-25 minutes. Envelopes were sealed, stamped with the school seal across the closure area, and later opened by me.

Mr. Samson Lemma traveled to Dongoro and administered the survey to Grade 9-12 students at Wollega Adventist Academy on March 20, 1998. Each grade was given the survey individually. Before Mr. Lemma handed out the survey, students were 
requested to space themselves around the room (or in the case of two classes, outside under the trees), were reminded to not put their name on the paper, and to place completed questionnaires in large envelopes provided by Mr. Lemma. The average time to fill out the questionnaire was 20-25 minutes. Envelopes were sealed, stamped with the school seal across the closure area, and delivered by Mr. Lemma directly to me.

The confidentiality of each student and his/her responses was maintained by (1) students not placing their name on the survey, (2) having students spaced around the room, (3) requesting no talking during the survey, and (4) having each student place his/her own survey in a large envelope or folder which was opened by me.

Students were asked to voluntarily fill out the questionnaire; a refusal would not have resulted in any penalty or loss of benefit. However, no student refused to participate in the survey.

\section{Data Collection and Analysis}

Data were coded according to school, grade level, age, gender, Seventh-day Adventist religious affiliation, length of Seventh-day Adventist school attendance, and communication with parent/adult. Data were analyzed using the Statistical Package for the Social Sciences (SPSS).

The independent variables measured were grade level, age, gender, SDA religious affiliation, length of attendance at SDA school, and communication with parent/adult. The dependent variables measured were questions 8 to 38 on the AIDS Survey for Students which describes HIV/AIDS-related beliefs, knowledge, and sexual behavior practices related to HIV/AIDS infection. The independent variable of 
communication with parent/adult was measured only with questions $36-38$, which dealt specifically with HIV/AIDS-related sexual behavior. Descriptive demographic data of the subjects were obtained by performing a frequency distribution on each of the 38 items. Statistical procedures using Chi-square were used to test the research questions.

Statistical significance was set at alpha $=0.05$.

\section{Summary}

This chapter explained the type of research, population description, development of the survey instrument used, how the survey was administered, and how the data were collected and analyzed. 


\section{CHAPTER IV}

\section{ANALYSIS OF DATA}

\section{Introduction}

The purpose of this study was to ascertain the impact that HIV/AIDS-related beliefs, knowledge, and demographic variables have on the sexual behavior of students attending Seventh-day Adventist boarding schools in Ethiopia. This chapter presents and discusses the findings of the survey to the variables of gender, age, grade, communication with parent or adult family member, and SDA affiliation in relation to the student responses towards HIV/AIDS-related beliefs, knowledge, and sexual behavior.

The 38-question survey contained questions relating to demographic, knowledge, belief, and sexual behavior patterns. Each of the knowledge, belief, and sexual behavior items were analyzed separately. The independent variables were grade $(9,10,11$, 12), gender (Male and Female), and religious affiliation (Seventh-day Adventist, or nonSeventh-day Adventist).

\section{Description of the Sample.}

The sample for this study consisted of 1,144 secondary students from the three Seventh-day Adventist boarding schools in Ethiopia. There was a total of 1,280 students registered in all three schools. Eighty-three percent, or 1,144 students, were present on the day of the survey and completed the questionnaire. Although there were some 
questionnaires that had missing data, this amounted to less than $5 \%$ for any question.

There was no individual analysis done for comparison between schools.

Table 1 shows that the number of students in each grade decreased from Grade $9(346)$ to Grade 12 (211). In the expected age range (14-19 years), $92.8 \%$ were highschool students. Six hundred and seventy-six $(59.8 \%)$ were males.

Surprisingly, more students indicated Orthodox as their religious preference (39.6\%), than Adventist (30.1\%). This coincides with the degree of SDA affiliation where only $37.7 \%$ of the responses indicated some degree of Adventist affiliation compared to $56.5 \%$ with none. The majority of the students $(43 \%)$ indicated that they had been attending an SDA school for 2-6 years, while only $13 \%$ had attended for 11 years or more.

\section{Descriptive Results}

The statistics are described under three categories. HIV/AIDS-related (1)

beliefs, (2) knowledge, and (3) sexual behavior practices. There are nine items related to the students beliefs which are discussed in the first section. Section two discusses the 19 questions that deal with knowledge, and section three discusses the findings from the four HIV/AIDS sexual intercourse-related questions.

\section{Research Question 1}

What are the beliefs towards HIV/AIDS among students attending Seventhday Adventist boarding schools in Ethiopia?

Ninth- through 12th-grade students attending Seventh-day Adventist boarding schools in Ethiopia answered a self-report survey on HIV/AIDS to identify the level of HIV/AIDS-related beliefs. The HIV/AIDS beliefs section of the survey consisted of nine 
Table 1. Demographic Characteristics of Academy Students Responding $(N=1,144)$

\begin{tabular}{|c|c|c|}
\hline Variable & $\%$ & $\mathrm{~N}$ \\
\hline \multicolumn{3}{|l|}{ 1. Grade } \\
\hline 9 & 30.2 & 346 \\
\hline 10 & 25.1 & 287 \\
\hline 11 & 26.1 & 299 \\
\hline 12 & 18.4 & 211 \\
\hline \multicolumn{3}{|l|}{ 2. Gender } \\
\hline Female & 39.7 & 454 \\
\hline Male & 59.1 & 676 \\
\hline \multicolumn{3}{|l|}{ 3. Age } \\
\hline $12-13$ & 1.6 & 18 \\
\hline $14-15$ & 21.7 & 248 \\
\hline $16-17$ & 42.5 & 486 \\
\hline $18-19$ & 28.1 & 322 \\
\hline $20-21$ & 4.0 & 46 \\
\hline $22-23$ & 1.6 & 18 \\
\hline \multicolumn{3}{|l|}{ 4. Religious Preference } \\
\hline Seventh-day Adventist & 29.6 & 339 \\
\hline Orthodox & 39.0 & 446 \\
\hline Muslim & 6.6 & 75 \\
\hline Other & 23.3 & 266 \\
\hline \multicolumn{3}{|l|}{ 5. Adventist Affiliation } \\
\hline Baptized member & 10.6 & 121 \\
\hline One or both parents baptized & 9.3 & 106 \\
\hline Raised in an Adventist home & 17.8 & 204 \\
\hline None & 56.5 & 646 \\
\hline \multicolumn{3}{|l|}{ 6. Length of Stay in Adventist School } \\
\hline $0-1$ year & 24.5 & 280 \\
\hline $2-6$ years & 43.1 & 493 \\
\hline $7-10$ years & 19.1 & 219 \\
\hline 11 years or more & 12.8 & 147 \\
\hline
\end{tabular}


questions where students were asked about their beliefs regarding HIV/AIDS. These items included questions dealing with whether they had been taught and should students be taught about HIV/AIDS in school, whether a student with HIV/AIDS should be allowed in school, if the student would want to be in the same class with another student who has HIV/AIDS, ability to obtain HIV/AIDS testing and information, and the level of communication regarding HIV/AIDS with friends, parents, or another adult in the family. Questions were answered by choosing "yes," "no," or "not sure." The results are presented in Table 2.

The majority of students (94.4\%) indicated that they felt students their age should be taught about HIV/AIDS infection in school, and almost three-fourths (72.6\%) reported that they had been taught about HIV/AIDS infection in school. Only $37.4 \%$ reported that a student with HIV/AIDS infection should be allowed to go to their school, while it is interesting to note that over half $(57.3 \%)$ of the students would be willing to be in the same class as someone with HIV/AIDS infection.

About one-third (31.6\%) reported that they did not know where to get good information about HIV/AIDS, and slightly less $(28.8 \%)$ knew where to go to get tested for AIDS. The vast majority $(90.1 \%)$ indicated they know how to keep from getting the HIV/AIDS virus. Over half (56.6\%) reported that they have talked with their parents or other adult family member about HIV/AIDS, while almost three-fourths (73.3\%) reported talking with a friend about it.

In summary, the overall level of beliefs towards HIV/AIDS of students attending SDA boarding schools in Ethiopia is reasonably accurate. 
Table 2. HIV/AIDS-Related Belief Responses Among Academy Students in Percentages $(N=1,144)$

\begin{tabular}{|c|c|c|c|}
\hline \multirow[t]{2}{*}{ Belief Item } & Yes & No & $\begin{array}{l}\text { Not } \\
\text { Sure }\end{array}$ \\
\hline & $\%(N)$ & $\%(N)$ & $\%(N)$ \\
\hline $\begin{array}{l}\text { 7. Should students your age be taught about } \\
\text { HIV/AIDS infection in school? }\end{array}$ & $\begin{array}{c}94.4 \\
(1,080)\end{array}$ & $\begin{array}{r}3.1 \\
(36)\end{array}$ & $\begin{array}{r}2.4 \\
(27)\end{array}$ \\
\hline $\begin{array}{l}\text { 8. Have you been taught about HIV/AIDS infection } \\
\text { in school? }\end{array}$ & $\begin{array}{l}72.6 \\
(831)\end{array}$ & $\begin{array}{r}22.9 \\
(262)\end{array}$ & $\begin{array}{r}4.4 \\
(50)\end{array}$ \\
\hline $\begin{array}{l}\text { 9. Should a student with HIV/AIDS infection be } \\
\text { allowed to go to your school? }\end{array}$ & $\begin{array}{l}37.4 \\
(428)\end{array}$ & $\begin{array}{r}25.6 \\
(293)\end{array}$ & $\begin{array}{r}36.9 \\
(422)\end{array}$ \\
\hline $\begin{array}{l}\text { 10. Would you be willing to be in the same class } \\
\text { with a student with HIV/AIDS infection? }\end{array}$ & $\begin{array}{c}57.3 \\
(655)\end{array}$ & $\begin{array}{r}30.4 \\
(348)\end{array}$ & $\begin{array}{r}12.2 \\
(140)\end{array}$ \\
\hline $\begin{array}{l}\text { 11. Do you know where to get good information } \\
\text { about HIV/AIDS infection? }\end{array}$ & $\begin{array}{c}57.2 \\
(654)\end{array}$ & $\begin{array}{r}31.6 \\
(362)\end{array}$ & $\begin{array}{r}11.1 \\
(127)\end{array}$ \\
\hline $\begin{array}{l}\text { 12. Do you know where to get tested to see if you are } \\
\text { infected with the AIDS virus? }\end{array}$ & $\begin{array}{l}61.5 \\
(704)\end{array}$ & $\begin{array}{r}28.8 \\
(330)\end{array}$ & $\begin{array}{r}9.5 \\
(109)\end{array}$ \\
\hline $\begin{array}{l}\text { 13. Do you know how to keep from getting the } \\
\text { HIV/AIDS virus? }\end{array}$ & $\begin{array}{c}90.1 \\
(1,031)\end{array}$ & $\begin{array}{r}6.0 \\
(69)\end{array}$ & $\begin{array}{r}3.8 \\
(43)\end{array}$ \\
\hline $\begin{array}{l}\text { 14. Have you ever talked about HIV/AIDS with a } \\
\text { friend? }\end{array}$ & $\begin{array}{c}73.3 \\
(838)\end{array}$ & $\begin{array}{r}22.4 \\
(256)\end{array}$ & $\begin{array}{r}4.3 \\
(49)\end{array}$ \\
\hline $\begin{array}{l}\text { 15. Have you ever talked about HIV/AIDS with your } \\
\text { parents or some other adult in your family? }\end{array}$ & $\begin{array}{c}56.6 \\
(648)\end{array}$ & $\begin{array}{r}39.1 \\
(447)\end{array}$ & $\begin{array}{r}4.2 \\
(48)\end{array}$ \\
\hline
\end{tabular}

Note. Total number of responses may vary due to missing data. 


\section{Research Question 2}

What is the knowledge level regarding HIV/AIDS among students attending Seventh-day Adventist boarding schools in Ethiopia?

Ninth- through 12th-grade students attending Seventh-day Adventist boarding schools in Ethiopia answered a self-report survey on HIV/AIDS to identify the level of HIV/AIDS-related knowledge. Nineteen HIV/AIDS-related knowledge questions on the survey assess the student's knowledge on how HIV/AIDS is acquired, how the virus is spread, ways to reduce chances of becoming infected, and l question assesses knowledge of whether a person can be cured from AIDS if diagnosed early.

The overall knowledge of students reporting on the survey was reasonably accurate. There seemed to be some confusion, however, for question 28 , which deals with the topic of homosexuality, and question 18, regarding transmission of HIV/AIDS by mosquitoes. Responses to these questions are presented and discussed as correct, incorrect, and not sure with the results found in Table 3.

Of the eight questions that dealt with knowledge on mode of HIV/AIDS transmission, all but two of them were answered correctly by the majority (more than $60 \%$ ) of the students. Question 18 dealt with whether you can get HIV/AIDS from being bitten by a mosquito which has already fed on a person with AIDS in which only $37.7 \%$ answered correctly compared to $41.4 \%$ who answered incorrectly. The mean and the median answer for question 18 , however, fell in the "not sure" category. The majority of students also answered incorrectly (55.9\%) that a person can get HIV/AIDS from donating blood. 
Table 3. HIV/AIDS-Related Knowledge Responses Among Academy Students in Percentages $(N=1,144)$

\begin{tabular}{|c|c|c|c|}
\hline \multirow[t]{2}{*}{ Knowledge Item } & Yes & No & $\begin{array}{l}\text { Not } \\
\text { Sure }\end{array}$ \\
\hline & $\%(N)$ & $\%(N)$ & $\%(N)$ \\
\hline $\begin{array}{l}\text { 16. Can a person get HIV/AIDS infection from } \\
\text { holding hands with someone? }\end{array}$ & $\begin{array}{c}9.4 \\
(107)\end{array}$ & $\begin{array}{l}82.6 \\
(945)\end{array}$ & $\begin{array}{r}8.0 \\
(91)\end{array}$ \\
\hline $\begin{array}{l}\text { 17. Can a person get HIV/AIDS infection from } \\
\text { sharing needles used to inject drugs? }\end{array}$ & $\begin{array}{c}89.2 \\
(1,020)\end{array}$ & $\begin{array}{r}7.3 \\
(84)\end{array}$ & $\begin{array}{r}3.4 \\
(39)\end{array}$ \\
\hline $\begin{array}{l}\text { 18. Can a person get HIV/AIDS from being bitten by } \\
\text { a mosquito which has already fed on a person } \\
\text { with AIDS? }\end{array}$ & $\begin{array}{l}41.4 \\
(474)\end{array}$ & $\begin{array}{c}37.7 \\
(431)\end{array}$ & $\begin{array}{l}20.8 \\
(238)\end{array}$ \\
\hline 19. Can a person get HIV/AIDS from donating blood? & $\begin{array}{c}55.9 \\
(640)\end{array}$ & $\begin{array}{l}31.7 \\
(363)\end{array}$ & $\begin{array}{r}12.2 \\
(140)\end{array}$ \\
\hline $\begin{array}{l}\text { 20. Can a person get HIV/AIDS from having blood } \\
\text { drawn with a sterile needle? }\end{array}$ & $\begin{array}{c}32.3 \\
(369)\end{array}$ & $\begin{array}{l}61.0 \\
(698)\end{array}$ & $\begin{array}{r}6.6 \\
(76)\end{array}$ \\
\hline $\begin{array}{l}\text { 21. Can a person get HIV/AIDS infection by } \\
\text { wearing clothes used by someone with AIDS? }\end{array}$ & $\begin{array}{c}13.5 \\
(154)\end{array}$ & $\begin{array}{c}69.8 \\
(799)\end{array}$ & $\begin{array}{r}16.6 \\
(190)\end{array}$ \\
\hline $\begin{array}{l}\text { 22. Can a person get HIV/AIDS infection from } \\
\text { having sexual intercourse without using a } \\
\text { condom (rubber)? }\end{array}$ & $\begin{array}{c}68.5 \\
(784)\end{array}$ & $\begin{array}{c}17.4 \\
(199)\end{array}$ & $\begin{array}{r}14.0 \\
(160)\end{array}$ \\
\hline $\begin{array}{l}\text { 23. Can a person get HIV/AIDS infection from being } \\
\text { in the same class with a student who has } \\
\text { HIV/AIDS? }\end{array}$ & $\begin{array}{r}9.7 \\
(111)\end{array}$ & $\begin{array}{r}79.9 \\
(914)\end{array}$ & $\begin{array}{r}10.3 \\
(118)\end{array}$ \\
\hline $\begin{array}{l}\text { 24. Can you tell if people are infected with the AIDS } \\
\text { virus (HIV) just by looking at them? }\end{array}$ & $\begin{array}{l}15.4 \\
(176)\end{array}$ & $\begin{array}{l}69.1 \\
(791)\end{array}$ & $\begin{array}{r}15.4 \\
(176)\end{array}$ \\
\hline $\begin{array}{l}\text { 25. Can a person who has the AIDS virus (HIV) } \\
\text { infect someone else during sexual intercourse? }\end{array}$ & $\begin{array}{l}86.8 \\
(993)\end{array}$ & $\begin{array}{c}8.9 \\
(102)\end{array}$ & $\begin{array}{r}4.1 \\
(47)\end{array}$ \\
\hline
\end{tabular}


Table 3--Contimued.

\begin{tabular}{|c|c|c|c|}
\hline \multirow{2}{*}{ Knowledge Item } & Yes & No & Not sure \\
\hline & $\%(N)$ & $\%(N)$ & $\%(N)$ \\
\hline $\begin{array}{l}\text { 26. Can a pregnant woman who has the AIDS virus } \\
\text { (HIV) infect her unborn baby with the virus? }\end{array}$ & $\begin{array}{r}88.1 \\
(1,008)\end{array}$ & $\begin{array}{r}6.5 \\
(74)\end{array}$ & $\begin{array}{r}5.2 \\
(60)\end{array}$ \\
\hline 27. Is there a cure for HIV/AIDS infection? & $\begin{array}{r}22.5 \\
(257)\end{array}$ & $\begin{array}{c}65.6 \\
(751)\end{array}$ & $\begin{array}{c}11.8 \\
(135)\end{array}$ \\
\hline $\begin{array}{l}\text { 28. Is it true that only homosexual men can get } \\
\text { HIV/AIDS infection? }\end{array}$ & $\begin{array}{r}25.9 \\
(296)\end{array}$ & $\begin{array}{r}43.1 \\
(493)\end{array}$ & $\begin{array}{l}30.9 \\
(354)\end{array}$ \\
\hline $\begin{array}{l}\text { 29. Can people reduce their chances of becoming } \\
\text { infected with the HIV/AIDS virus by not having } \\
\text { any kind of sexual intercourse (being abstinent)? }\end{array}$ & $\begin{array}{r}50.3 \\
(575)\end{array}$ & $\begin{array}{r}34.7 \\
(397)\end{array}$ & $\begin{array}{c}14.9 \\
(171)\end{array}$ \\
\hline $\begin{array}{l}\text { 30. Can people reduce their chances of becoming } \\
\text { infected with the AIDS virus (HIV) by using } \\
\text { condoms (rubbers) during sexual intercourse? }\end{array}$ & $\begin{array}{r}69.3 \\
(793)\end{array}$ & $\begin{array}{c}18.2 \\
(208)\end{array}$ & $\begin{array}{c}12.4 \\
(142)\end{array}$ \\
\hline $\begin{array}{l}\text { 31. Can people reduce their chances of becoming } \\
\text { infected with the AIDS virus (HIV) by not } \\
\text { having any kind of sexual intercourse with a } \\
\text { person who has injected (shot up) drugs? }\end{array}$ & $\begin{array}{r}28.1 \\
(322)\end{array}$ & $\begin{array}{c}51.5 \\
(589)\end{array}$ & $\begin{array}{c}20.3 \\
(232)\end{array}$ \\
\hline $\begin{array}{l}\text { 32. Can people reduce their chances of becoming } \\
\text { infected with the AIDS virus (HIV) by taking } \\
\text { birth control pills? }\end{array}$ & $\begin{array}{r}11.5 \\
(131)\end{array}$ & $\begin{array}{l}80.1 \\
(916)\end{array}$ & $\begin{array}{r}8.4 \\
(96)\end{array}$ \\
\hline 33. Can AIDS be cured if it is diagnosed early? & $\begin{array}{r}12.7 \\
(145)\end{array}$ & $\begin{array}{c}76.9 \\
(880)\end{array}$ & $\begin{array}{c}10.3 \\
(118)\end{array}$ \\
\hline $\begin{array}{l}\text { 34. Can you catch AIDS by sharing needles/syringes } \\
\text { with someone who has the AIDS virus? }\end{array}$ & $\begin{array}{r}81.9 \\
(937)\end{array}$ & $\begin{array}{r}13.6 \\
(156)\end{array}$ & $\begin{array}{r}4.4 \\
(50)\end{array}$ \\
\hline
\end{tabular}

Note. Total number of responses may vary due to missing data. 
More than half $(51.5 \%)$ of the students responded incorrectly when asked if people can reduce their chances of becoming infected with HIV/AIDS by not having any kind of sexual intercourse with a person who has injected drugs. However, the vast majority (89.2\%) of respondents answered correctly when asked if a person can get HIV/AIDS infection from sharing needles used to inject a drug.

Item 28 asks whether only homosexual men can get HIV/AIDS infection. In this question although their was a greater percentage (43.1\%) that answered correctly, it should be noted that a large number $(30.9 \%)$ answered "not sure."

It is interesting to note that in the belief question on whether the student would be willing to be in the same class with a student who has HIV/AIDS infection, only slightly over half ( $57.3 \%$ ) stated they would, whereas $79.9 \%$ stated correctly that they could not get HIV/AIDS infection from being in the same class with someone who has the infection.

There were six of the general knowledge questions that the vast majority (more than $80 \%$ ) of students answered correctly. For example, the following questions, "Can a person get HIV/AIDS infection from holding hands with someone?" (82.6\%); "Can a person get HIV/AIDS infection from sharing needles to inject drugs?" (89.2\%); "Can a person who has the AIDS virus (HIV) infect someone else during sexual intercourse?" (86.8\%); "Can a pregnant woman who has the AIDS virus (HIV) infect her unborn baby with the virus?" (88.1\%); "Can people reduce their chances of becoming infected with the AIDS virus (HIV) be taking birth control pills?" (80.1\%); and "Can you catch AIDS by sharing needles/syringes with someone who has the AIDS virus?" (81.9\%), were answered correctly by the indicated percentage. 
In summary, the overall knowledge level regarding HIV/AIDS of students attending SDA boarding schools in Ethiopia is reasonably accurate with the exception of questions 18 and 24.

\section{Research Question 3}

What are the sexual behaviors in relation to HIV/AIDS among students attending Seventh-day Adventist boarding schools in Ethiopia?

Ninth- through 12th-grade students attending Seventh-day Adventist boarding schools in Ethiopia answered a self-report survey to assess the level of HIV/AIDS-related sexual behavior. Four questions on the survey dealt with sexual behavior regarding number of sexual partners, age, and condom usage. The results are found on Table 4.

Students were asked to respond to the two questions inquiring about the number of sexual partners students had had. For example, when asked, "With how many people have you had any kind of sexual intercourse in your life?" $73.8 \%$ reported that they had not had any sexual intercourse, $6.1 \%$ reported 1 partner, $5.2 \%$ reported 2 partners, $2.5 \%$ reported 3 partners, and $12.2 \%$ reported 4 or more partners. Similarly, when asked, "With how many people have you had any kind of sexual intercourse in the last year?" $79.8 \%$ indicated " 0 " or no sexual activity, and again the highest percentage (7.3\%) being similar to the preceding question with 4 or more partners.

Once again, the response for question 37 coincides closely with the preceding two questions when students were asked how old they were when they first had sexual intercourse, with $74.3 \%$ indicating that they have had no sexual intercourse. The same 
Table 4. HIV/AIDS-Related Behavior Responses Among Academy Students in Percentages $(N=1,144)$

\begin{tabular}{|c|c|c|c|c|c|}
\hline \multirow[t]{2}{*}{ Sexual Behavior } & 0 & 1 & 2 & 3 & $\begin{array}{l}4 \text { or } \\
\text { more }\end{array}$ \\
\hline & $\%(N)$ & $\%(N)$ & $\%(N)$ & $\%(N)$ & $\%(N)$ \\
\hline $\begin{array}{l}\text { 35. With how many people have you had any } \\
\text { kind of sexual intercourse in your life? }\end{array}$ & $\begin{array}{r}73.8 \\
(844)\end{array}$ & $\begin{array}{r}6.1 \\
(70)\end{array}$ & $\begin{array}{l}5.2 \\
(60)\end{array}$ & $\begin{array}{l}2.5 \\
(29)\end{array}$ & $\begin{array}{c}12.2 \\
(140)\end{array}$ \\
\hline \multirow[t]{2}{*}{$\begin{array}{l}\text { 36. With how many people have you had } \\
\text { any kind of sexual intercourse in the } \\
\text { last year? }\end{array}$} & $\begin{array}{r}79.8 \\
(913)\end{array}$ & $\begin{array}{r}6.8 \\
(78)\end{array}$ & $\begin{array}{l}3.7 \\
(42)\end{array}$ & $\begin{array}{c}2.4 \\
(27)\end{array}$ & $\begin{array}{c}7.3 \\
(83)\end{array}$ \\
\hline & & & & $\%$ & $(N)$ \\
\hline \multicolumn{4}{|c|}{$\begin{array}{l}\text { 37. How old were you the first time you had any kind of sexual } \\
\text { intercourse? }\end{array}$} & & \\
\hline Never had ar & $\begin{array}{l}\text { ind of se } \\
12 \text { year } \\
17 y\end{array}$ & $\begin{array}{l}\text { ual inter } \\
\text { old or y } \\
3-14 \text { ye } \\
-16 \text { ye } \\
\text { ars old }\end{array}$ & $\begin{array}{l}\text { ourse } \\
\text { unger } \\
\text { s old } \\
\text { s old } \\
\text { older }\end{array}$ & $\begin{array}{r}74.3 \\
7.0 \\
4.5 \\
9.4 \\
4.7\end{array}$ & $\begin{array}{c}(850) \\
(80) \\
(52) \\
(107) \\
(54)\end{array}$ \\
\hline \multicolumn{4}{|c|}{$\begin{array}{l}\text { 38. When you have any kind of sexual intercourse, how often is condom } \\
\text { (rubber) used? }\end{array}$} & & \\
\hline \multicolumn{4}{|c|}{ I have never had any kind of sexual intercourse } & 74.3 & $(850)$ \\
\hline \multicolumn{4}{|c|}{ Always } & 7.8 & $(89)$ \\
\hline \multicolumn{4}{|c|}{ Sometimes } & 4.5 & (51) \\
\hline \multicolumn{4}{|c|}{ Rarely } & 4.1 & $(47)$ \\
\hline \multicolumn{4}{|c|}{ Never } & 9.3 & $(106)$ \\
\hline
\end{tabular}


number reported again no sexual activity to the last question when asked how often they use a condom when they have sexual intercourse.

The average age students reported having their first sexual intercourse experience was between 15-16 years (9.4\%); however, the next most frequent answer was 12 years old or younger $(7.0 \%)$. Thirteen to 14 years old was reported by $4.5 \%$ and very similar was 17 years old or older with $4.7 \%$ reporting.

A total of 230 students (20.2\%) responded that they had had some sexual experience in the last year while, in comparison, only $89(7.8 \%)$ indicated that they always use a condom, and $793(69.3 \%)$ indicated that they knew people can reduce their chances of becoming infected with HIV/AIDS by using a condom during sexual intercourse. The largest response to use of a condom during sexual intercourse was "never," 9.3\%.

In summary the overall sexual activity within the last year is minimal, not yet approaching one-fourth $(20.2 \%)$, while condom usage is still low.

\section{Research Question 4}

Is there a relationship between grade level and beliefs toward HIV/AIDS among students attending SDA boarding schools in Ethiopia?

Ninth-through 12th-grade students attending Seventh-day Adventist boarding schools in Ethiopia answered a self-report survey to assess the relationship between grade level and beliefs towards HIV/AIDS. Nine questions deal with students' beliefs towards HIV/AIDS. The results in relationship to grade are presented in Table 5 and in Table 22 in Appendix A. 
There was no statistical relationship between grade level and response to the following questions, "Should students your age be taught about HIV/AIDS infection in school?" "Would you be willing to be in the same class with a student with HIV/AIDS infection?" "Do you know where to get tested to see if you are infected with the HIV/AIDS virus?" "Do you know how to keep from getting the HIV/AIDS virus?" and "Have you ever talked about HIV/AIDS with your parents or some other adult in your family?"

When students were asked whether they had been taught about HIV/AIDS infection in school, there was statistical significance based on a 0.05 level where only $70.5 \%$ of Grade 9 students said they have been, whereas the percentage rose in Grade 12 students' responses to $82 \% \cdot\left(\chi^{2}=20.247, d f=6, p<0.003\right)$.

Students were also asked whether "a student with HIV/AIDS infection should be allowed to go to your school?" Student responses showed a general increase in belief, however, slightly over one-third of Grade 9 and 10 students (31.2\% and $35.5 \%)$ and nearly half of Grade 11 (40.1\%) and Grade 12 students (43.6\%) said they were "unsure."

It is interesting to note that almost the same number of Grade 9 students $(60.1 \%)$ and Grade 12 students $(60.2 \%)$ stated they know where to get good HIV/AIDS information whereas fewer Grade 10 (53.3\%) and Grade 11 (55.5\%) students know $\left(\chi^{2}=31.872, d f=6, p=000\right)$. It cannot be clearly stated, therefore, that as grade increases students know where to get good HIV/AIDS information because of the sharp decrease from Grade 9 to Grade 10. 
Table 5. Chi-square Results of HIV/AIDS - Related Belief Responses Among Academy Students in Relation to Grade

\begin{tabular}{|l|c|c|}
\hline Belief & $\chi^{2}$ & Prob $^{\mathrm{a}}$ \\
\hline $\begin{array}{l}\text { 7. Should students your age be taught about } \\
\text { HIV/AIDS infection in school? }\end{array}$ & 5.321 & 0.503 \\
$\begin{array}{l}\text { 8. Have you been taught about HIV/AIDS } \\
\text { infection in school? }\end{array}$ & 20.247 & $0.003^{* *}$ \\
$\begin{array}{l}\text { 9. Should a student with HIV/AIDS infection be } \\
\text { allowed to go to your school? }\end{array}$ & 19.187 & $0.004^{* *}$ \\
$\begin{array}{l}\text { 10. Would you be willing to be in the same class with } \\
\text { a student with HIV/AIDS infection? }\end{array}$ & 16.061 & $0.013^{*}$ \\
$\begin{array}{l}\text { 11. Do you know where to get good information } \\
\text { about HIV/AIDS infection? }\end{array}$ & 31.872 & $0.000^{* *}$ \\
$\begin{array}{l}\text { 12. Do you know where to get tested to see if you } \\
\text { are infected with the HIV/AIDS virus? }\end{array}$ & 8.680 & 0.192 \\
$\begin{array}{l}\text { 13. Do you know hovv to keep from getting the HIV/AIDS virus? } \\
\text { 14. Have you ever talked about HIV/AIDS with a friend? } \\
\text { 15. Have you ever talked about HIV/AIDS with your }\end{array}$ & 9.149 & 0.165 \\
\hline
\end{tabular}

${ }^{\mathrm{a}} d f=6$.

${ }^{*} p \leq 0.05$. ** $p \leq 0.01$. 
There was a steady increase in the percentage of students from Grades 9 to 12 that said, "yes," they have talked about HIV/AIDS with a friend. This clearly indicates that, as a student increases in grade level, he/she is more apt to talk about HIV/AIDS with friends.

In summary it is seen that of the nine grade level and belief questions, five student responses showed that there was no difference in belief toward grade level, whereas four identified that there was a statistically significant difference.

\section{Research Question 5}

Is there a relationship between grade levels and knowledge level regarding HIV/AIDS among students attending Seventh-day Adventist boarding schools in Ethiopia?

Ninth- through $12^{\text {th }}$ grade students attending Seventh-day Adventist boarding schools in Ethiopia answered a self-report survey to assess the relationship between grade level and the level of HIV/AIDS-related knowledge. In order to determine the relationship between students' knowledge of HIV/AIDS and their grade in school, a Chi-square test was performed on each of the 19 knowledge questions. Eleven of the questions proved to be statistically significant based on a 0.05 level of significance. Answers are discussed using correct, incorrect, and "not sure" as responses and are presented in Table 6, and Table 23 in Appendix A.

There was no statistical relationship between knowledge and Grades $9,10,11$, and 12 students' responses to the questions, "Can a person get HIV/AIDS infection from holding hands with someone?" "Can a person get HIV/AIDS infections from sharing 
needles used to inject drugs?" "Can a person get HIV/AIDS infection by wearing clothes used by someone who has the AIDS virus?" "Can a person who has the AIDS virus (HIV) infect someone else during sexual intercourse?" "Is there a cure for HIV/AIDS infection?" "Can people reduce their chances of becoming infected with the HIV/AIDS virus by not having any kind of sexual intercourse?" "Can people reduce their chances of becoming infected with the AIDS virus (HIV) by using condoms (rubbers) during sexual intercourse?" and "Can people reduce their chances of becoming infected with the AIDS virus (HIV) by taking birth control pills?"

Of the 19 knowledge questions, there was a statistically significant relationship in 12 questions. Although the percentage of correct responses to "Can a person get HIV/AIDS from being bitten by a mosquito which has fed on a person with AIDS?" was low and well below half for all Grades $9(30.3 \%), 10(37.6 \%), 11(41.1 \%), 12(45.0 \%)$, there was a trend indicating an increase in knowledge from Grade 9 to Grade 12 $\left(\chi^{2}=27.772, d f=6, p=.000\right)$.

More than half of students in Grades 9,10,11,12 answered incorrectly to the question, "Can a person get HIV/AIDS from donating blood?" There was an increase in incorrect answers from Grade $9(52.3 \%)$ to Grade $10(60.3 \%)$ with the incorrect responses then decreasing in Grade 11 (57.5\%) and again decreasing to Grade $12(54.0 \%)$ $\left(\chi^{2}=16.632, d f=6, p=.011\right)$. 
Table 6. Chi-square Results of HIV/AIDS-Related Knowledge Responses Among Academy Students in Relation to Grade

\begin{tabular}{|c|c|c|}
\hline Knowledge & $\chi^{2}$ & Prob $^{a}$ \\
\hline $\begin{array}{l}\text { 16. Can a person get HIV/AIDS infection } \\
\text { from holding hands with someone? }\end{array}$ & 8.264 & 0.219 \\
\hline $\begin{array}{l}\text { 17. Can a person get HIV/AIDS infection from } \\
\text { sharing needles used to inject drugs? }\end{array}$ & 12.417 & .053 \\
\hline $\begin{array}{l}\text { 18. Can a person get HIV/AIDS from being bitten } \\
\text { by a mosquito which has fed on a person with AIDS? }\end{array}$ & 27.772 & $.000 * *$ \\
\hline 19. Can a person get HIV/AIDS from donating blood? & 16.632 & $.011^{*}$ \\
\hline $\begin{array}{l}\text { 20. Can a person get HIV/AIDS from having blood } \\
\text { drawn with a sterile needle? }\end{array}$ & 22.820 & $.001 * *$ \\
\hline $\begin{array}{l}\text { 21. Can a person get HIV/AIDS infection by wearing } \\
\text { clothes used by someone who has the AIDS virus? }\end{array}$ & 10.704 & .098 \\
\hline $\begin{array}{l}\text { 22. Can a person get HIV/AIDS infection from having } \\
\text { sexual intercourse without using a condom? }\end{array}$ & 18.884 & $.004^{* *}$ \\
\hline $\begin{array}{l}\text { 23. Can a person get HIV/AIDS infection from being in } \\
\text { the same class with a student who has AIDS/HIV infection? }\end{array}$ & 14.006 & $.030^{*}$ \\
\hline $\begin{array}{l}\text { 24. Can you tell if people are infected with the AIDS } \\
\text { virus (HIV) just by looking at them? }\end{array}$ & 25.064 & $.000 * *$ \\
\hline $\begin{array}{l}\text { 25. Can a person who has the AIDS virus (HIV) infect } \\
\text { someone else during sexual intercourse? }\end{array}$ & 8.041 & .530 \\
\hline $\begin{array}{l}\text { 26. Can a pregnant woman who has the AIDS virus (HIV) } \\
\text { infect her unborn baby with the virus? }\end{array}$ & 15.382 & $.017^{*}$ \\
\hline 27. Is there a cure for HIV/AIDS infection? & 3.449 & .751 \\
\hline $\begin{array}{l}\text { 28. Is it true that only homosexual men can get the } \\
\text { HIV/AIDS infection? }\end{array}$ & 16.459 & $.011^{*}$ \\
\hline
\end{tabular}


Table 6--Continued

\begin{tabular}{|l|c|c|}
\hline Knowledge & $\chi^{2}$ & Prob $^{\mathbf{2}}$ \\
\hline $\begin{array}{l}\text { 29. Can people reduce their chances of becoming infected } \\
\text { with the HIV/AIDS virus by not having any kind of } \\
\text { sexual intercourse? }\end{array}$ & 8.520 & .202 \\
$\begin{array}{l}\text { 30. Can people reduce their chances of becoming infected } \\
\text { with the AIDS virus (HIV) by using condoms (rubbers) } \\
\text { during sexual intercourse? }\end{array}$ & 7.408 & .285 \\
$\begin{array}{l}\text { 31. Can people reduce their chances of becoming infected } \\
\text { with the AIDS virus (HIV) by not having any kind of } \\
\text { sexual intercourse with a person who has injected (shot } \\
\text { up) drugs? }\end{array}$ & 18.911 & $.004^{* *}$ \\
$\begin{array}{l}\text { 32. Can people reduce their chances of becoming infected } \\
\text { with the AIDS virus (HIV) by taking birth control pills? }\end{array}$ & 10.591 & .102 \\
$\begin{array}{l}\text { 33. Can AIDS be cured if it is diagnosed early? } \\
\begin{array}{l}\text { 34. Can you catch the AIDS virus by sharing } \\
\text { needles/syringes with someone who has the AIDS virus? }\end{array}\end{array}$ & 19.611 & $.003^{* *}$ \\
\hline
\end{tabular}

${ }^{\mathrm{a}} d f=6$.

${ }^{*} p \leq 0.05 .{ }^{* *} p \leq 0.01$. 
Grade 9 students were more knowledgeable (63.6\%) than Grade $10(51.2 \%)$ and Grade 11 (60.2) students, but slightly less knowledgeable than Grade 12 students (71.6\%) when asked, "Can a person get HIV/AIDS from having blood drawn with a sterile needle?" $\left(\chi^{2}=22.820, d f=6, p=.001\right)$.

The percentage of "yes" responses to "Can a person get HIV/AIDS infection from having sexual intercourse without using a condom (rubber)?"' increased from Grade 9 to 12 , however Grade 10 students had the highest $(72.1 \%)$ percentage of correct response $\left(\chi^{2}=18.884, d f=6, p=.004\right)$. More than three-fourths of the students in all grades responded correctly with a "no" answer to "Can a person get HIV/AIDS infection from being in the same class with a student who has AIDS/HIV infection?" Grade 12 students had the largest percentage (87.2\%) and Grade 10 students had the lowest percentage $(76.3 \%)\left(\chi^{2}=14.006, d f=6, p=.030\right)$.

The general knowledge for the question dealing with whether you can tell if a person is infected with HIV/AIDS by looking at them increased as grade increased. However, the number of people in the class who were "unsure" also increased $\left(\chi^{2}=25.064, d f=6, p=.000\right)$.

The vast majority of students in Grades 9, 10, 11, and 12 answered "yes" to "Can a pregnant woman who has the AIDS virus (HIV) infect her unborn baby with the virus?" with Grade 9 having the least percentage (84.1\%) and Grade 12 the highest percentage at $91.9 \%\left(\chi^{2}=15.382, d f=6, p=.017\right)$.

The degree of uncertainty was high by students in all grades when asked "Is it true that only homosexual men can get the HIV/AIDS virus?" based on the fact that 
almost one-third of all students answered with "not sure." Grade 12 students again had the most correct responses with $51.2 \%$ answering "no" $\left(\chi^{2}=16.459, d f=6, p=.011\right)$.

It is surprising to see that students in all grades answered incorrectly to the question, "Can people reduce their chances of becoming infected with the AIDS virus (HIV) by not having any kind of sexual intercourse with a person who has injected (shot up) drugs?" More than half of all students in Grades 9, 10, and 12 answered incorrectly and nearly half of Grade 11 answered incorrectly. Knowledge level actually decreased from Grade $12(57.3 \%)$ to Grade $9(50.9 \%)$ in incorrect answers $\left(\chi^{2}=18.911, d f=6\right.$, $p=.004)$.

The majority of students in all grades answered correctly ("no") when asked "Can AIDS be cured if it is diagnosed early?" Grade 11 students had the most correct percentage (81.6\%) and Grade 9 had the least $(72.3 \%)\left(\chi^{2}=16.650, d f=6, p=.011\right)$.

More than three-fourths of all students in Grades 9, 10,11, and 12 responded correctly to "Can you catch AIDS by sharing needles/syringes with someone who has the AIDS virus?" Grade 10 students gave the correct answer more frequently (86.1\%) followed by Grade $12(81.5 \%)$ than Grade $11(81.3 \%)$ and the least frequency of correct answers by Grade $9(79.5 \%)\left(\chi^{2}=19.611, d f=6, p=.003\right)$.

In summary of the 12 knowledge questions that showed a statistically significant difference between grades, all but 2 showed an increase in knowledge in relation to grade. It can therefore be assumed that as students progress in grade, knowledge also increases. 


\section{Research Question 6}

Is there a relationship between grade levels and sexual behavior in relation to HIV/AIDS among students attending Seventh-day Adventist boarding schools in Ethiopia?

Ninth- through 12th-grade students attending Seventh-day Adventist boarding schools in Ethiopia answered a self-report survey to assess the relationship between grade level and sexual behavior.

The relationship between students' sexual behavior and their grade in school was determined by performing a Chi-square test on each of the four behavior questions. The results are shown in Table 7 (and Table 24 in Appendix A).

In responding to the question, "With how many people have you had any kind of sexual intercourse in the last year?" it is noted that as the grade increased, the students were more sexually active; however, there is no clear trend as to the number of partners. Students in the upper grades were older when they had their first sexual experience. There is also a general trend indicating that students are having sexual experiences at a younger age $\left(\chi^{2}=34.950, d f=12, p=.000\right)$.

When students were asked the question "When you have any kind of sexual intercourse, how often is a condom (rubber) used?" although there is significant difference between grades, there is no clear trend $\left(\chi^{2}=28.198, d f=12, p=.005\right)$.

In summary it can be stated that although there were statistically significant differences between behavior and grade, there are no clear trends. 
Table 7. Chi-square Results of HIV/AIDS-Related Behavior Responses Among Academy Students in Relation to Grade

\begin{tabular}{|l|c|c|}
\hline Behavior & $\chi^{2}$ & Prob $^{\mathbf{a}}$ \\
\hline $\begin{array}{l}\text { 35. With how many people have you had any kind of sexual } \\
\text { intercourse in your life? }\end{array}$ & 17.637 & .127 \\
$\begin{array}{l}\text { 36. With how many people have you had any kind of sexual } \\
\text { intercourse in the last year? }\end{array}$ & 24.080 & $.020^{*}$ \\
$\begin{array}{l}\text { 37. How old were you the first time you had any kind of sexual } \\
\text { intercourse? }\end{array}$ & 34.950 & $.000^{* *}$ \\
$\begin{array}{l}\text { 38. When you have any kind of sexual intercourse, how often is a } \\
\text { condom (rubber) used? }\end{array}$ & 28.198 & $.005^{* *}$ \\
\hline
\end{tabular}

a $d f=12$.

${ }^{*} p \leq 0.05$. ${ }^{* *} p \leq 0.01$.

\section{Research Question 7}

Is there a relationship between age and beliefs towards HIV/AIDS among students attending SDA boarding schools in Ethiopia?

Ninth- through 12th-grade students attending Seventh-day Adventist boarding schools in Ethiopia answered a survey on HIV/AIDS to identify the relationship between age and beliefs towards HIV/AIDS.

Students were asked nine belief questions in relation to HIV/AIDS. Chi-square tests were performed to examine the relationship between age and responses to the belief questions. Statistically significant results at the 0.05 probability level were found on six of the questions. It should be noted here that on the original questionnaire, there were six different age groups for students to choose from. To obtain cell counts above five, options 
five (ages 20-21) and six (22-23) were combined. Table 8 shows the results of the Chisquare analysis, and Table 25 in Appendix A reveals the percentage.

On the first belief question, there was a very noticeable upward trend where the older a student was, the more they felt that students their age should be taught about HIV/AIDS infection in school. Of the 12-13-year-olds, $66.7 \%$ indicated "yes," whereas of the 20-23-year-olds, $96.9 \%$ indicated "yes." Only $38.9 \%$ of $12-13$-year-olds reported that they had been taught about HIV/AIDS in school, and more than twice (79.7\%) that number of ages 20-23 reported "yes."

When students were asked, "Do you know how to keep from getting the HIV/AIDS virus?" more than $80 \%$ of all students said yes, with $83.3 \%$ of $12-13$-year-olds saying "yes" and the responses going upward to 18-19-year-olds saying "yes" $92.2 \%$ of the time $\left(\chi^{2}=21.376, d f=8, p=.006\right)$.

The older students, $18-23$ years, $81.6 \%$ of the time stated that they have talked with a friend about HIV/AIDS, whereas only $50.0 \%$ of $12-13$-year-olds say that they have $\left(\chi^{2}=42.121, d f=8, p .000\right)$. There is a sharp trend noticed when students were asked if they have talked with their parents or another adult about HIV/AIDS. Of the 12-13-year-olds, only $16.7 \%$ said they had and $65.6 \%$ of $20-23$-year-olds said that they had spoken with an adult family member.

In summary, of the nine belief questions, six showed a definite trend that there is a relationship between age and belief about HIV/AIDS where the older a student is, the more positive the belief. 
Table 8. Chi-square Results of HIV/AIDS-Related Belief Responses Among Academy Students in Relation to Age

\begin{tabular}{|l|c|c|}
\hline Belief & \multicolumn{1}{|c|}{ Item } & Prob $^{2}$ \\
\hline $\begin{array}{l}\text { 7. Should students your age be taught about HIV/AIDS } \\
\text { infection in chool? }\end{array}$ & 57.628 & $.000^{* *}$ \\
8. Have you been taught about HIV/AIDS infection in school? & 47.899 & $.000^{* *}$ \\
$\begin{array}{l}\text { 9. Should a student with HIV/AIDS infection be allowed } \\
\text { to go to your school? }\end{array}$ & 17.058 & $.030^{*}$ \\
$\begin{array}{l}\text { 10. Would you be willing to be in the same class with a } \\
\text { student with HIV/AIDS infection? }\end{array}$ & 7.495 & .484 \\
$\begin{array}{l}\text { 11. Do you know where to get good information about } \\
\text { HIV/AIDS infection? }\end{array}$ & 10.082 & .259 \\
$\begin{array}{l}\text { 12. Do you know where to get tested to see if you are } \\
\text { infected with the HIV/AIDS virus? }\end{array}$ & 5.931 & .655 \\
$\begin{array}{l}\text { 13. Do you know how to keep from getting the } \\
\text { HIV/AIDS virus? }\end{array}$ & 21.376 & $.006^{* *}$ \\
$\begin{array}{l}\text { 14. Have you ever talked about HIV/AIDS with a friend? } \\
\text { 15. Have you ever talked about HIV/AIDS with your parents } \\
\text { or some other adult in your family? }\end{array}$ & 28.609 & $.000^{* *}$ \\
\hline
\end{tabular}

" $d f=8$.

${ }^{*} p \leq 0.05{ }^{* *} p \leq 0.01$. 
Although there is an upward trend of students who felt that a student with HIV/AIDS should be allowed to attend "your school," all percentages were low at less than $50 \%$. However, when asked if they would be willing to be in the same class with a student with HIV/AIDS, $50 \%$ or more of all age groups responded positively.

\section{Research Question 8}

Is there a relationship between age and knowledge level regarding HIV/AIDS among students attending Seventh-day Adventist boarding schools in Ethiopia?

Ninth- through 12th-grade students attending Seventh-day Adventist boarding schools in Ethiopia answered a self-report survey on HIV/AIDS to identify the relationship between age and HIV/AIDS-related knowledge.

Students were asked 19 knowledge questions in relation to HIV/AIDS. Chisquare tests were performed and yielded statistically significant results at the .05 probability level on six of the questions. It should be noted here that on the original questionnaire, there were six different age groups for students to choose from. To obtain cell counts above five, options five (ages 20-21) and six (22-23) were combined. The results of the Chi-square analysis are shown in Table 9, and Table 26 in Appendix A reveals the percentage

In response to the question, "Can a person get HIV/AIDS infection from holding hands with someone?" there was an increase in knowledge from 12-13-year-olds, where $55.6 \%$ answered correctly, and 20-23-year-olds, where $87.5 \%$ answered correctly 
Table 9. Chi-square Results of HIV/AIDS-Related Knowledge Responses Among Academy Students in Relation to Age

\begin{tabular}{|c|c|c|}
\hline Knowledge & $\chi^{2}$ & Prob $^{a}$ \\
\hline $\begin{array}{l}\text { 16. Can a person get HIV/AIDS infection from } \\
\text { holding hands with someone? }\end{array}$ & 21.070 & $.007^{* *}$ \\
\hline & 12.814 & .118 \\
\hline $\begin{array}{l}\text { 17. Can a person get HIV/AIDS infection from } \\
\text { sharing needles used to inject drugs? }\end{array}$ & 29.780 & $.000 * *$ \\
\hline $\begin{array}{l}\text { 18. Can a person get HIV/AIDS from being bitten } \\
\text { by a mosquito which has fed on a person with AIDS? }\end{array}$ & 13.710 & .090 \\
\hline 19. Can a person get HIV/AIDS from donating blood? & 16.061 & $.042^{*}$ \\
\hline $\begin{array}{l}\text { 20. Can a person get HIV/AIDS from having blood } \\
\text { drawn with a sterile needle? }\end{array}$ & 12.981 & .112 \\
\hline $\begin{array}{l}\text { 21. Can a person get HIV/AIDS infection by wearing } \\
\text { clothes used by someone who has the AIDS virus? }\end{array}$ & 18.527 & $.018^{*}$ \\
\hline $\begin{array}{l}\text { 22. Can a person get HIV/AIDS infection from having } \\
\text { sexual intercourse without using a condom? }\end{array}$ & 5.688 & .682 \\
\hline $\begin{array}{l}\text { 23. Can a person get HIV/AIDS infection from being } \\
\text { in the same class with a student who has AIDS/HIV infection? }\end{array}$ & 34.172 & $.000^{* *}$ \\
\hline $\begin{array}{l}\text { 24. Can you tell if people are infected with the AIDS } \\
\text { virus (HIV) just by looking at them? }\end{array}$ & 15.125 & .235 \\
\hline $\begin{array}{l}\text { 25. Can a person who has the AIDS virus (HIV) infect } \\
\text { someone else during sexual intercourse? }\end{array}$ & & \\
\hline $\begin{array}{l}\text { 26. Can a pregnant woman who has the AIDS virus (HIV) } \\
\text { infect her unborn baby with the virus? }\end{array}$ & 28.104 & $.000^{* *}$ \\
\hline 27. Is there a cure for HIV/AIDS infection? & 14.246 & .076 \\
\hline $\begin{array}{l}\text { 28. Is it true that only homosexual men can get the HIV/AIDS } \\
\text { Infection? }\end{array}$ & 14.243 & .076 \\
\hline
\end{tabular}


Table 9--Continued.

\begin{tabular}{|l|c|c|}
\hline Knowledge & \multicolumn{1}{|c|}{ Item } & Prob $^{\mathrm{a}}$ \\
\hline $\begin{array}{l}\text { 29. Can people reduce their chances of becoming } \\
\text { infected with the HIV/AIDS virus by not having } \\
\text { any kind of sexual intercourse? }\end{array}$ & 3.631 & .889 \\
$\begin{array}{l}\text { 30. Can people reduce their chances of becoming infected } \\
\text { with the AIDS virus (HIV) by using ondoms (rubbers) } \\
\text { during sexual intercourse? }\end{array}$ & 6.677 & .572 \\
$\begin{array}{l}\text { 31. Can people reduce their chances of becoming infected } \\
\text { with the AIDS virus (HIV) by not having any kind of } \\
\text { sexual intercourse with a person who has injected (shot up) drugs? }\end{array}$ & 7.219 & .513 \\
$\begin{array}{l}\text { 32. Can people reduce their chances of becoming infected } \\
\text { with the AIDS virus (HIV) by taking birth control pills? }\end{array}$ & 6.563 & .584 \\
$\begin{array}{l}\text { 33. Can AIDS be cured if it is diagnosed early? } \\
\begin{array}{l}\text { 34. Can you catch the AIDS virus by sharing needles/syringes } \\
\text { with someone who has the AIDS virus? }\end{array}\end{array}$ & 5.924 & .766 \\
\hline
\end{tabular}

${ }^{a} d f=8$.

${ }^{*} p \leq 0.05$. ${ }^{* *} p \leq 0.01$. 
$\left(\chi^{2}=21.070, d f=8, p=.007\right)$. More than $80 \%$ of all age groups except for the 12-13-yearolds, answered this question correctly.

There was a increase in knowledge, illustrated by the decrease in percentage of incorrect answers to, "Can a person get HIV/AIDS from being bitten by a mosquito which has fed on a person with AIDS?" where 55.6\% of 12-13-year-olds answered incorrectly and only $34.4 \%$ of the $20-23$-year-olds answered incorrectly $\left(\chi^{2}=29.780, d f=8, p=.000\right)$.

Although the Chi-square results did not show a statistical significance in knowledge in relation to age for question 19 , there is a noticeable decrease in knowledge from the $12-13$-year-olds ( $44.4 \%$ answered incorrectly) to the $20-23$-year-olds ( $68.8 \%$ answered incorrectly) $\left(\chi^{2}=13.710, d f=8, p=.090\right)$. A decrease in knowledge was also seen by the percentage of correct responses of 20-23-year-olds (48.4\%) in comparison to the 12-13-year-olds (77.8\%) to "Can a person get AIDS infection from having blood drawn with a sterile needle?" $\left(\chi^{2}=16.061, d f=8, p=.042\right)$. As age increased, knowledge also increased with regard to the question, "Can a person get HIV/AIDS infection from having sexual intercourse without using a condom?" $\left(\chi^{2}=18.527, d f=8, p-.018\right)$. All age groups responded correctly more than $60 \%$ of the time with $12-13$-year-olds answering correctly (61.1\%) and $20-23$-year-olds $81.3 \%$ of the time.

There was a vast difference and a clear trend in increase in knowledge by age to the question, "Can you tell if people are infected with the AIDS virus (HIV) just by looking at them?" $\left(\chi^{2}=34.172, d f=8, p=.000\right)$. Only $22.2 \%$ of $12-13$-year-olds answered correctly compared to $73.4 \%$ of $20-23$-year-olds. 
Knowledge also increased in question 26 where students were asked whether a mother can pass the virus to her unborn child; however, there was no clear trend $\left(\chi^{2}=28.104, d f=8, p=.000\right)$.

In summary, of the six statistically significant questions, five of them showed an increase in HIV/AIDS-related knowledge with age and only one question did not.

\section{Research Question 9}

Is there a relationship between age and sexual behavior in relation to HIV/AIDS among students attending Seventh-day Adventist boarding schools in Ethiopia?

Ninth- through 12th-grade students attending Seventh-day Adventist boarding schools in Ethiopia answered a self-report survey on HIV/AIDS-related knowledge. The survey contained four sexual-activity behavior questions in relation to HIV/AIDS. Chisquare tests were performed and yielded statistically significant results at the .05 probability level on all four of the questions. It should be noted here that on the original questionnaire, there were six different age groups for students to choose from. To obtain cell counts above five, options five (ages 20-21) and six (22-23) were combined. The results of the Chi-square analysis are presented in Table 10 (and Table 27 in Appendix A).

When students were asked, "With how many people have you had any kind of sexual intercourse in your life?" there was a general trend for people to be more sexually active with age. By far the biggest group, apart from those who have had no sexual intercourse, is the $12-13$-year-olds in which $27.9 \%$ stated that they have had $4+$ sexual 
partners. We ought to be careful in over-generalizing this as there were only 18 students in this age category compared to 248 in the 14-15-year-old category and $486,16-17$-yearolds $\left(\chi^{2}=50.739, d f=16, p=.000\right)$.

Table 10. Chi-square Results of HIV/AIDS-Related Behavior Responses Among Academy Students in Relation to Age

\begin{tabular}{|l|r|r|}
\hline Behavior & \multicolumn{1}{|c|}{$\chi^{2}$} & Prob $^{\mathbf{a}}$ \\
\hline $\begin{array}{l}\text { 35. With how many people have you had any kind } \\
\text { of sexual intercourse in your life? }\end{array}$ & 50.739 & $.000^{* *}$ \\
$\begin{array}{l}\text { 36. With how many people have you had any kind } \\
\text { of sexual intercourse in the last year? }\end{array}$ & 37.467 & $.002^{* *}$ \\
$\begin{array}{l}\text { 37. How old were you the first time you had any kind } \\
\text { of sexual intercourse? }\end{array}$ & 65.952 & $.000^{* *}$ \\
$\begin{array}{l}\text { 38. When you have any kind of sexual intercourse, how often } \\
\text { is a condom (rubber) used? }\end{array}$ & 35.525 & $.003^{* *}$ \\
\hline
\end{tabular}

${ }^{3} d f=16$.

${ }^{*} p \leq 0.05$. ** $p \leq 0.01$.

Question 36 asks how many sexual partners the students had in the last year.

Once again, the most sexually active age group was the 12-13-year-olds where only

$61.1 \%$ indicated having no sexual partners in the last year compared to $13-14$-year-olds of which $86.7 \%$ reported no partners. With the exception of the $12-13$-year-olds the general trend is that sexual behavior increases with age $\left(\chi^{2}=37.467, d f=16, p=.002\right)$. 
In answering question 37 it seems that sexual intercourse is occurring at a younger age. However, these results should be interpreted with caution as some of the percentage differences in cells were not that large.

When asked the frequency of condom usage during sexual intercourse, $17.2 \%$ of the 20-23-year-olds indicated that they seldom or rarely use a condom, while $4.0 \%$ of the 14-15-year-olds indicated that they seldom or rarely do $\left(\chi^{2}=35.525, d f=16, p=.003\right)$.

In summary, keeping in mind that the 12-13-year-olds represented only 18 of the total 1,144 students surveyed, this age group was the most sexually active and used condoms next to the least amount. Therefore, the general trend, excluding this age group, was that as age increased, sexual intercourse frequency increased and condom usage decreased.

\section{Research Question 10}

Is there a relationship between gender and belief towards HIV/AIDS among students attending Seventh-day Adventist boarding schools in Ethiopia?

Ninth- through 12th-grade students attending Seventh-day Adventist boarding schools in Ethiopia answered a self-report survey on HIV/AIDS-related beliefs. A Chisquare test of independence was performed on each of the nine belief questions to test the research question. Of the nine belief questions, four were statistically significant based on a 0.05 probability level, with "yes" being the correct answer. Table 11 and Table 28 (in Appendix A) illustrate the statistical analysis results.

No statistical differences were found in the answers between female and male students when they were asked "Should students your age be taught about HIV/AIDS 
infection in school?" "Should a student with HIV/AIDS infection be allowed to go to your school?" "Do you know where to get good information about HIV/AIDS?" "Do you know where to get tested to see if you are infected with the AIDS virus?" and "Do you know how to keep from getting the HIV/AIDS virus?"

More females $(78.2 \%)$ than males $(69.7 \%)$ indicated that they had been taught about HIV/AIDS in school $\left(\chi^{2}=10.271, d f=2, p=.006\right)$. However, more males $(61.2 \%)$ than females ( $51.5 \%)$ answered positively that they would be willingtobe in the same class with a student with HIV/AIDS infection $\left(\chi^{2}=10.826, d f=2, p=.004\right)$.

When students were asked, "Have you ever talked about HIV/AIDS with a friend?" $76.8 \%$ of the males indicated that they had, compared to only $67.6 \%$ of the females $\left(\chi^{2}=13.051, d f=2, p=.001\right)$. In comparison, more females $(63.2 \%)$ than males $(52.7 \%)$ indicated that they had talked about HIV/AIDS with their parents or some other adult family member $\left(\chi^{2}=13.325, d f=2, p=.001\right)$. However, it should be noted that communication is still low, based on the large percentage of both genders (female $34.1 \%$, male $42.6 \%$ ) that indicated they had not communicated with an adult family member. In summary, the responses of students attending Seventh-day Adventist boarding schools in Ethiopia on the HIV/AIDS-related questionnaire indicated that there was a statistical difference between gender in almost half (four out of nine questions) of the belief questions. 
Table 11. Chi-square Results of HIV/AIDS-Related Belief Responses Among Academy Students in Relationship to Gender

\begin{tabular}{|c|c|c|}
\hline Belief & $\chi^{2}$ & Prob $^{\mathrm{a}}$ \\
\hline $\begin{array}{l}\text { 7. Should students your age be taught about } \\
\text { HIV/AIDS infection in school? }\end{array}$ & 5.751 & .056 \\
\hline $\begin{array}{l}\text { 8. Have you been taught about HIV/AIDS infection } \\
\text { in school? }\end{array}$ & 10.271 & $.006^{* *}$ \\
\hline $\begin{array}{l}\text { 9. Should a student with HIV/AIDS infection be } \\
\text { allowed to go to your school? }\end{array}$ & 5.236 & .073 \\
\hline $\begin{array}{l}\text { 10. Would you be willing to be in the same class with } \\
\text { a student with HIV/AIDS infection? }\end{array}$ & 10.826 & $.004^{* *}$ \\
\hline $\begin{array}{l}\text { 11. Do you know where to get good information about } \\
\text { HIV/AIDS infection? }\end{array}$ & 4.576 & .101 \\
\hline $\begin{array}{l}\text { 12. Do you know where to get tested to see if you are } \\
\text { infected with the HIV/AIDS virus? }\end{array}$ & 1.607 & .448 \\
\hline $\begin{array}{l}\text { 13. Do you know how to keep from getting the } \\
\text { HIV/AIDS virus? }\end{array}$ & 3.986 & .136 \\
\hline 14. Have you ever talked about HIV/AIDS with a friend? & 13.051 & $.001^{* *}$ \\
\hline $\begin{array}{l}\text { 15. Have you ever talked about HIV/AIDS with your parents } \\
\text { or some other adult in your family? }\end{array}$ & 13.325 & $.001^{* *}$ \\
\hline
\end{tabular}

a $d f=2$.

${ }^{*} p \leq 0.05$. ** $p \leq 0.01$. 


\section{Research Question 11}

Is there a relationship between gender and knowledge level in relation to HIV/AIDS among students attending Seventh-day Adventist boarding schools in Ethiopia?

Ninth-through 12th-grade students attending Seventh-day Adventist boarding schools in Ethiopia answered a self-report survey on HIV/AIDS to identify if there was a relationship between gender and HIV/AIDS-related knowledge. A Chi-square test of independence was performed on each of the 19 knowledge questions to test the research question. Of the 19 belief questions, only 2 were statistically significant based on a 0.05 probability level. Table 12 and Table 29 (in Appendix A) illustrate the statistical analysis results.

There was a statistically significant difference in gender response to the question, "Can a person get HIV/AIDS infection from being bitten by a mosquito which has fed on a person with AIDS?" where males answered correctly $44.4 \%$ of the time and females $28.2 \%$. However, over-generalization should be avoided here as the number of males and females who were unsure are nearly the same (males $20.7 \%$, females $20.4 \%$. Also more than one-third of males $(35.2 \%)$ and more than half $(51.1 \%)$ of females answered incorrectly. Therefore, it is indicative that there is a lack of knowledge in both genders on mosquito transmission $\left(\chi^{2}=35.291, d f=2, p=.000\right)$.

A statistical significance between genders was also found to the question "Is it true that only homosexual men can get the HIV/AIDS infection?" A greater percentage of males $(48.1 \%)$ than females $(35.7 \%)$ responded correctly $\left(\chi^{2}=24.121, d f=2, p=.000\right)$, 
Table 12. Chi-Square Results of HIV/AIDS-Related Knowledge Responses Among Academy Students in Relationship to Gender

\begin{tabular}{|c|c|c|}
\hline Knowledge & $\chi^{2}$ & Prob $^{a}$ \\
\hline $\begin{array}{l}\text { 16. Can a person get HIV/AIDS infection from } \\
\text { holding hands with someone? }\end{array}$ & 2.684 & .261 \\
\hline $\begin{array}{l}\text { 17. Can a person get HIV/AIDS infection from sharing } \\
\text { needles used to inject drugs? }\end{array}$ & 1.910 & .385 \\
\hline $\begin{array}{l}\text { 18. Can a person get HIV/AIDS from being bitten by a } \\
\text { mosquito which has fed on a person with AIDS? }\end{array}$ & 35.291 & $.000 * *$ \\
\hline 19. Can a person get HIV/AIDS from donating blood? & 3.373 & .185 \\
\hline $\begin{array}{l}\text { 20. Can a person get HIV/AIDS from having blood } \\
\text { drawn with a sterile needle? }\end{array}$ & 1.108 & .575 \\
\hline $\begin{array}{l}\text { 21. Can a person get HIV/AIDS infection by wearing } \\
\text { clothes used by someone who has the AIDS virus? }\end{array}$ & .586 & .746 \\
\hline $\begin{array}{l}\text { 22. Can a person get HIV/AIDS infection from having } \\
\text { sexual intercourse without using a condom? }\end{array}$ & 1.911 & .385 \\
\hline $\begin{array}{l}\text { 23. Can a person get HIV/AIDS infection from being } \\
\text { in the same class with a student who has AIDS/HIV } \\
\text { infection? }\end{array}$ & .634 & .728 \\
\hline $\begin{array}{l}\text { 24. Can you tell if people are infected with the AIDS virus } \\
\text { (HIV) by looking at them? }\end{array}$ & 3.595 & .166 \\
\hline $\begin{array}{l}\text { 25. Can a person who has the AIDS virus (HIV) infect } \\
\text { someone else during sexual intercourse? }\end{array}$ & 1.450 & .694 \\
\hline $\begin{array}{l}\text { 26. Can a pregnant woman who has the AIDS virus (HIV) } \\
\text { Infect her unborn baby with the virus? }\end{array}$ & .424 & .809 \\
\hline
\end{tabular}


Table 12--.Continued.

\begin{tabular}{|c|c|c|}
\hline Knowledge & $\chi^{2}$ & Prob $^{a}$ \\
\hline 27. Is there a cure for HIV/AIDS infection? & 4.392 & .111 \\
\hline $\begin{array}{l}\text { 28. Is it true that only homosexual men can get } \\
\text { the HIV/AIDS infection? }\end{array}$ & 24.121 & $.000 * *$ \\
\hline $\begin{array}{l}\text { 29. Can people reduce their chances of becoming } \\
\text { infected with the HIV/AIDS virus by not having } \\
\text { any kind of sexual intercourse? }\end{array}$ & 3.324 & .190 \\
\hline $\begin{array}{l}\text { 30. Can people reduce their chances of becoming } \\
\text { infected with the AIDS virus (HIV) by using } \\
\text { condoms (rubbers) during sexual intercourse? }\end{array}$ & 3.443 & .179 \\
\hline $\begin{array}{l}\text { 31. Can people reduce their chances of becoming } \\
\text { infected with the AIDS virus (HIV) by not having } \\
\text { any sexual intercourse with a person who has } \\
\text { injected (shot up) drugs? }\end{array}$ & .554 & .758 \\
\hline $\begin{array}{l}\text { 32. Can people reduce their chances of becoming infected } \\
\text { with the AIDS virus (HIV) by taking birth control } \\
\text { pills? }\end{array}$ & 1.584 & .453 \\
\hline 33. Can AIDS be cured if it is diagnosed early? & 2.967 & .227 \\
\hline $\begin{array}{l}\text { 34. Can you catch the AIDS virus by sharing } \\
\text { needles/syringes with someone who has the } \\
\text { AIDS virus? }\end{array}$ & .829 & .661 \\
\hline
\end{tabular}

${ }^{\mathrm{a}} d f=2$.

${ }^{*} p \leq 0.05$. ${ }^{* *} p \leq 0.01$. 
however, both females (38.5\%) and males (25.7\%) had a high level of unsure responses.

Although there was no statistical significance between genders to the question "Can a person get HIV/AIDS from donating blood?" it is interesting to note that more than half of males (56.4\%) and females (55.7\%) answered incorrectly.

In summary, the responses of students indicated that generally there was no statistical difference between gender and knowledge regarding HIV/AIDS.

\section{Research Question 12}

Is there a relationship between gender and sexual behavior in relation to HIV/AIDS among students attending Seventh-day Adventist boarding schools in Ethiopia?

Ninth- through 12th-grade students attending Seventh-day Adventist boarding schools in Ethiopia answered a survey on HIV/AIDS to identify if there was any relationship between gender and sexual behavior. A Chi-square test of independence was performed on each of the last four questions which dealt with sexual behavior. Table 13 and Table 30 (in Appendix A) illustrate the results of the Chi-square analysis on these questions. On all four questions it was noted that the females consistently answered between $89.0 \%$ and $90.5 \%$ that they had never had any sexual intercourse, in comparison to males who reported from $63.9 \%$ to $72.9 \%$.

In answering, "With how many people have you had any kind of sexual intercourse in your life?" fewer males (63.9\%) answered "0" compared to females $(89.0 \%)$. On the same question it was noted that four times as many males $(17.2 \%)$ indicated having " 4 or more" partners compared to females $(4.8 \%)\left(\chi^{2}=90.462, d f=4\right.$, 
Table 13. Chi-square Results of HIV/AIDS-Related Behavior Responses Among Academy Students in Relationship to Gender

\begin{tabular}{|l|c|c|}
\hline Behavior & $\chi^{2}$ & Prob $^{\mathrm{a}}$ \\
\hline $\begin{array}{l}\text { 35. With how many people have you had any kind of sexual } \\
\text { intercourse in your life? }\end{array}$ & 90.46 & $.000^{* *}$ \\
$\begin{array}{l}\text { 36. With how many people have you had any kind of sexual } \\
\text { intercourse in the last year? }\end{array}$ & 53.14 & $.000^{* *}$ \\
$\begin{array}{l}\text { 37. How old were you the first time you had any kind of sexual } \\
\text { intercourse? }\end{array}$ & 93.35 & $.000^{* *}$ \\
$\begin{array}{l}\text { 38. When you have any kind of sexual intercourse, how often is } \\
\text { a condom (rubber) used? }\end{array}$ & 91.56 & $.000^{* *}$ \\
\hline
\end{tabular}

${ }^{\mathrm{a}} d f=4$.

${ }^{*} p \leq 0.05{ }^{* *} p \leq 0.01$.

$p=.000$ ). Almost three times as many males $(9.6 \%)$ indicated that they had " 4 or more" partners in the last year, whereas the females' response (3.5\%) was less.

Males reported most frequently at having their first sexual experience between ages 15-16 years (14.6\%), with females most frequently reported age was 12-years-old or younger (4.4\%). However, $8.4 \%$ of males reported having their first sexual experience 12 years old or younger $\left(\chi^{2}=93.352, d f=4, p=.000\right)$.

When asked about the frequency of condom usage during sexual intercourse, $11.7 \%$ of males indicated they never use a condom while almost half that amount, $5.5 \%$, of females did $\left(\chi^{2}=91.555, d f=4, p=.000\right)$. 
In summary, it can be seen that males generally begin having sexual intercourse at a younger age, have had more sexual partners, and use a condom less frequently than do females.

\section{Research Question 13}

Is there a relationship between Seventh-day Adventist religious affiliation and belief towards HIVIAIDS among students attending Seventh-day Adventist boarding schools in Ethiopia?

Ninth- through 12th-grade students attending Seventh-day Adventist boarding schools in Ethiopia answered a self-report survey on HIV/AIDS to identify if there was a relationship between SDA religious affiliation and HIV/AIDS-related beliefs. On the survey, students were given a choice of four levels of Seventh-day Adventist (SDA) affiliation: baptized member, one of both parents baptized members, raised in Adventist home, and "none." When analyzed, the first three choices were grouped together as having some SDA affiliation and the last choice as "none."

A Chi-square test of independence was performed on each of the nine questions which dealt with HIV/AIDS-related beliefs. Based on a 0.05 probability level, there was no statistical significant difference to the questions, "Should students your age be taught about HIV/AIDS infection in school?" "Do you know where to get good information about HIV/AIDS infection?" "Do you know where to get tested to see if you are infected with the HIV/AIDS virus?" and "Do you know how to keep from getting the HIV/AIDS virus?" Five questions were statistically significant. Table 14 and Table 31 (in Appendix A) illustrate the results of the Chi-square analysis. 
When students were asked, "Have you been taught about HIV/AIDS infection in school?" $79.6 \%$ of students with SDA affiliation indicated "yes" compared to $66.0 \%$ of students with no SDA affiliation $\left(\chi^{2}=19.600, d f=2, p=.000\right)$.

In response to question 9, "Should a student with HIV/AIDS infection be allowed to go to your school?" more than one-fourth of all students reported "no." Those students with SDA affiliation (28.9\%) and those students who have no SDA affiliation $(25.1 \%)$ indicated "no" in response to this question. An equal number $(28.9 \%)$ of SDA affiliates indicated "not sure" compared to a considerable larger number of non-SDA affiliates $(41.1 \%)\left(\chi^{2}=13.410, d f=2, p=.001\right)$. One needs to be careful with overgeneralization, however, on this question as $41.1 \%$ of non-SDA affiliates were "not sure" and $28.9 \%$ with SDA affiliation were "not sure."

More than half of all students answered "yes" to question 10 where they indicated they would be willing to be in the same class with a student who has HIV/AIDS infection. Statistics showed, however, there are fewer of those with SDA affiliation (50.4\%) who indicated yes, compared to almost $15 \%$ more of those with no SDA affiliation $(64.4 \%)\left(\chi^{2}=20.819, d f=2, p=.000\right)$.

It is interesting to compare the results of questions 9 and 10 . In question 9 more students with SDA affiliation indicated that a student with HIV/AIDS should be allowed in their school; however, in question 10 there were fewer students with SDA affiliation who indicated they would be willing to be in the same class with someone who does have the HIV/AIDS virus. We can therefore say that although there is statistical difference in preference of HIV/AIDS students attending school and in whether a student would want to be in the same class as one, there is no clear trend. 
Table 14. Chi-square Results of HIV/AIDS-Related Belief Among Academy Students in Relationship to Religious Affiliation

\begin{tabular}{|l|r|l|}
\hline Belief & \multicolumn{1}{|c|}{ Item } & Prob $^{\mathrm{a}}$ \\
\hline $\begin{array}{l}\text { 7. Should students your age be taught about } \\
\text { HIV/AIDS infection in school? }\end{array}$ & 0.77 & .680 \\
$\begin{array}{l}\text { 8. Have you been taught about HIV/AIDS infection } \\
\text { in school? }\end{array}$ & 19.600 & $.000^{* *}$ \\
$\begin{array}{l}\text { 9. Should a student with HIV/AIDS infection be } \\
\text { allowed to go to your school? }\end{array}$ & 13.410 & $.001^{* *}$ \\
$\begin{array}{l}\text { 10. Would you be willing to be in the same class with } \\
\text { a student with HIV/AIDS infection? }\end{array}$ & 20.819 & $.000^{* *}$ \\
$\begin{array}{l}\text { 11. Do you know where to get good information about } \\
\text { HIV/AIDS infection? }\end{array}$ & .534 & .766 \\
$\begin{array}{l}\text { 12. Do you know where to get tested to see if you are } \\
\text { infected with the HIV/AIDS virus? }\end{array}$ & 5.073 & .079 \\
$\begin{array}{l}\text { 13. Do you know how to keep from getting the } \\
\text { HIV/AIDS virus? }\end{array}$ & 2.958 & .228 \\
$\begin{array}{l}\text { 14. Have you ever talked about HIV/AIDS with a friend? } \\
\text { 15. Have you ever talked about HIV/AIDS with your } \\
\text { parents or some other adult in your family? }\end{array}$ & 9.808 & $.007^{* *}$ \\
\hline
\end{tabular}

${ }^{\mathrm{a}} d f=2$.

${ }^{*} p \leq 0.05{ }^{* *} p \leq 0.01$. 
Two belief questions dealt with communication. Question 14 asked, "Have you ever talked about HIV/AIDS with a friend?" and question 15, "Have you ever talked about HIV/AIDS with your parents or some other adult in your family?" More then three-fourths $(77.7 \%)$ of those with SDA affiliation indicated that they had talked with a friend about HIV/AIDS, whereas $69.4 \%$ of non-SDA affiliates indicated that they had $\left(\chi^{2}=9.808, d f=2, p=.007\right)$. Similarly, more of those with SDA affiliation $(63.1 \%)$ reported "yes" to question 15 and again a lesser number (48.0\%) of those with non-SDA affiliation reporting "yes" to the same question $\left(\chi^{2}=20.851, d f=2, p=.000\right)$.

In conclusion, it can be stated that students with SDA affiliation have more communication with friends or family about HIV/AIDS than those students with no SDA affiliation. Of the three other statistically significant belief questions, although the students with SDA affiliation responded correctly to two of them, there is no clear trend.

\section{Research Question 14}

Is there a relationship between Seventh-day Adventist religious affiliation and knowledge level in relation to HIV/AIDS among students attending Seventh-day Adventist boarding schools in Ethiopia?

Ninth- through 12th-grade students attending Seventh-day Adventist boarding schools in Ethiopia answered a self-report survey on HIV/AIDS to identify if there was a relationship between SDA religious affiliation and HIV/AIDS-related knowledge. On the survey, students were given a choice of four levels of Seventh-day Adventist (SDA) affiliation: baptized member, one or both parents baptized members, raised in Adventist 
home, and "none." When analyzed, the first three choices were grouped together as having some SDA affiliation and the last choice as "none."

A Chi-square test of independence was performed on each of the 19 questions which dealt with HIV/AIDS-related knowledge. Based on a 0.05 probability level, there was a statistical significant difference in six of the questions. The results can be seen in Table 15 and Table 32 (in Appendix A).

When students were asked, "Can a person get HIV/AIDS from donating blood?" $67.9 \%$ of students with SDA affiliation answered incorrectly "yes" compared to $49.4 \%$ of those with non-SDA affiliation $\left(x^{2}=29.473, d f=2, p=.000\right)$. Only $53.8 \%$ of SDA-affiliated students reported correctly "no" when asked, "Can a person get HIV/AIDS from having blood drawn with a sterile needle?" with $65.3 \%$ of non-SDA affiliation correctly reporting "no" ( $\left.\chi^{2}=15.241, d f=2, p=.000\right)$. When students were asked, "Is there a cure for HIV/AIDS infection," fewer students with SDA affiliation (61.5\%) reported correctly "no" compared to those with non-SDA affiliation (71.7\%) $\left(\chi^{2}=9.481, d f=2, p=.009\right)$.

In answering question 28 which states, "Is it true that only homosexual men can get the HIV/AIDS infection?" $48.7 \%$ non-SDA-affiliated students answered correctly "no" with only $37.4 \%$ of SDA-affiliated students responding correctly. However, over-generalization should be avoided on this question because there were large percentages of both SDA-affiliated and non-SDA-affiliated students who reported "not sure" $(27.9 \%$ and $31.0 \%$ respectively $) \quad\left(\chi^{2}=22.445, d f=2, p=.000\right)$. 
Table 15. Chi-square Results of HIV/AIDS-Related Knowledge Responses Among Academy Students in Relationship to Religious Affiliation

\begin{tabular}{|c|c|c|}
\hline Knowledge & $\chi^{2}$ & Prob $^{a}$ \\
\hline $\begin{array}{l}\text { 16. Can a person get HIV/AIDS infection from } \\
\text { holding hands with someone? }\end{array}$ & 2.456 & 0.293 \\
\hline $\begin{array}{l}\text { 17. Can a person get HIV/AIDS infection from sharing } \\
\text { needles used to inject drugs? }\end{array}$ & .599 & .741 \\
\hline $\begin{array}{l}\text { 18. Can a person get HIV/AIDS from being bitten by } \\
\text { a mosquito which has fed on a person with AIDS? }\end{array}$ & .597 & .742 \\
\hline 19. Can a person get HIV/AIDS from donating blood? & 29.473 & $.000^{* *}$ \\
\hline $\begin{array}{l}\text { 20. Can a person get HIV/AIDS from having blood } \\
\text { drawn with a sterile needle? }\end{array}$ & 15.241 & $.000^{* *}$ \\
\hline $\begin{array}{l}\text { 21. Can a person get HIV/AIDS infection by wearing } \\
\text { clothes used by someone who has the AIDS virus? }\end{array}$ & 3.515 & .173 \\
\hline $\begin{array}{l}\text { 22. Can a person get HIV/AIDS infection from having } \\
\text { sexual intercourse without using a condom? }\end{array}$ & .569 & .752 \\
\hline $\begin{array}{l}\text { 23. Can a person get HIV/AIDS infection from being in } \\
\text { the same class with a student who has HIV/AIDS } \\
\text { infection? }\end{array}$ & .618 & .734 \\
\hline $\begin{array}{l}\text { 24. Can you tell if people are infected with the AIDS virus } \\
\text { (HIV) just by looking at them? }\end{array}$ & 2.157 & .340 \\
\hline $\begin{array}{l}\text { 25. Can a person who has the AIDS virus (HIV) infect } \\
\text { someone else during sexual intercourse? }\end{array}$ & 1.425 & .700 \\
\hline $\begin{array}{l}\text { 26. Can a pregnant woman who has the AIDS virus (HIV) } \\
\text { infect her unborn baby with the virus? }\end{array}$ & 1.765 & .414 \\
\hline 27. Is there a cure for HIV/AIDS infection? & 9.481 & $.009^{* *}$ \\
\hline $\begin{array}{l}\text { 28. Is it true that only homosexual men can get the } \\
\text { HIV/AIDS infection? }\end{array}$ & 22.445 & $.000 * *$ \\
\hline
\end{tabular}


Table 15--Contimued.

\begin{tabular}{|c|c|c|}
\hline Knowledge & $\chi^{2}$ & Prob $^{a}$ \\
\hline $\begin{array}{l}\text { 29. Can people reduce their chances of becoming infected } \\
\text { with the HIV/AIDS virus by not having any kind } \\
\text { of sexual intercourse? }\end{array}$ & 1.514 & .469 \\
\hline $\begin{array}{l}\text { 30. Can people reduce their chances of becoming infected } \\
\text { with the AIDS virus (HIV) by using condoms (rubbers) } \\
\text { during sexual intercourse? }\end{array}$ & 13.528 & $.001 * *$ \\
\hline $\begin{array}{l}\text { 31. Can people reduce their chances of becoming infected } \\
\text { with the AIDS virus (HIV) by not having any kind of } \\
\text { sexual intercourse with a person who has injected (shot up) } \\
\text { drugs? }\end{array}$ & .495 & .781 \\
\hline $\begin{array}{l}\text { 32. Can people reduce their chances of becoming infected with } \\
\text { the AIDS virus (HIV) by taking birth control pills? }\end{array}$ & 2.334 & .311 \\
\hline 33. Can AIDS be cured if it is diagnosed carly? & 1.663 & .435 \\
\hline $\begin{array}{l}\text { 34. Can you catch the AIDS virus by sharing needles/syringes } \\
\text { with someone who has the AIDS virus? }\end{array}$ & 11.313 & $.003^{* *}$ \\
\hline
\end{tabular}

a $d f=2$.

${ }^{*} p \leq 0.05$. ${ }^{* *} p \leq 0.01$. 
Regarding SDA-affiliated students, $63.7 \%$ of these, compared to $75.4 \%$ of non-SDA-affiliated students, responded correctly to "Can people reduce their chances of becoming infected with the AIDS virus (HIV) by using condoms (rubbers) during sexual intercourse?" $\left(\chi^{2}=13.528, d f=2, p=001\right)$.

The last knowledge question with statistical significance was question 34 . Non-SDA-affiliated students reported $84.8 \%$ of the time correctly compared to $75.6 \%$ of SDA-affiliated students $\left(\chi^{2}=11.313, d f=2, p=.003\right)$.

In all six of the statistically significant knowledge questions relating to religious affiliation, non-SDA-affiliated students reported correctly by a higher percentage than did the SDA-affiliated students. In summary, it can therefore be said that non-SDA-affiliated students have more knowledge of HIV/AIDS than do the SDA-affiliated students.

\section{Research Question 15}

Is there a relationship between Seventh-day Adventist religious affiliation and sexual behavior in relation to HIV/AIDS among students attending Seventh-day Adventist boarding schools in Ethiopia?

Ninth- through 12th-grade students attending Seventh-day Adventist boarding schools in Ethiopia answered a self-report survey on HIV/AIDS to identify if there was a relationship between SDA affiliation and HIV/AIDS-related sexual behavior. On the survey, students were given a choice of four levels of Seventh-day Adventist (SDA) affiliation: baptized member, one or both parents baptized members, raised in Adventist home, and "none." When analyzed, the first three choices were grouped together as having some SDA affiliation and the last choice as "none." 
A Chi-square test of independence was performed on each of the four questions which dealt with HIV/AIDS-related sexual behavior. Based on a 0.05

probability level, there were no statistically significant differences in any of the questions. The results can be seen in Table 16 and Table 33 (in Appendix A).

In responding to all questions, more than $70 \%$ of all students indicated that they have never had any sexual intercourse. It can also be seen that $20 \%$ to $30 \%$ of all students are sexually active, with only $9.4 \%$ for non-SDA and $10 \%$ for SDA-affiliated students using a condom $\left(\chi^{2}=1.875, d f=4, p=0.759\right)$.

In summary it can therefore be stated that there is no statistical difference in the practice of sexual intercourse and condom usage between SDA-affiliated and nonSDA-affiliated students.

\section{Research Question 16}

Is there a relationship between years of attendance at Seventh-day Adventist boarding schools and beliefs towards HIVIAIDS among students attending Seventh-day Adventist boarding schools in Ethiopia?

Ninth- through 12th-grade students attending Seventh-day Adventist boarding schools in Ethiopia answered a self-report survey on HIV/AIDS to identify if there was a relationship between length of stay at Seventh-day Adventist schools and HIV/AIDSrelated beliefs. On the survey, students were given a choice of four levels of years in attendance: 0-1 years, 2-6 years, 7-10 years, and 11 years or more.

A Chi-square test of independence was performed on each of the nine questions which dealt with HIV/AIDS-related belief. Based on a 0.05 probability level, 
Table 16. Chi-square Results of HIV/AIDS-Related Behavior Responses Among Academy Students in Relationship to Religious Affiliation

\begin{tabular}{|l|c|c|}
\hline Behavior & \multicolumn{1}{|c|}{$\chi^{2}$} & Prob $^{\mathrm{a}}$ \\
\hline $\begin{array}{l}\text { 35. With how many people have you had any kind of } \\
\text { sexual intercourse in your life? }\end{array}$ & .569 & 0.966 \\
$\begin{array}{l}\text { 36. With how many people have you had any kind of } \\
\text { sexual intercourse in the last year? }\end{array}$ & 1.678 & 0.795 \\
$\begin{array}{l}\text { 37. How old were you the first time you had any kind of } \\
\text { sexual intercourse? }\end{array}$ & 1.697 & 0.791 \\
$\begin{array}{l}\text { 38. When you have any kind of sexual intercourse, how } \\
\text { often is a condom (rubber) used? }\end{array}$ & 1.875 & 0.759 \\
\hline
\end{tabular}

${ }^{2} d f=4$.

${ }^{*} p \leq 0.05$. ** $p \leq 0.01$

there were two statistically significant differences in the responses. The results can be seen in Table 17 and Table 34 (in Appendix A).

There were no statistical differences in responses to the questions "Have you been taught about HIV/AIDS infection in school?" "Should a student with HIV/AIDS infection be allowed to go to your school?" "Would you be willing to be in the same class with a student with HIV/AIDS infection?" "Do you know where to get good information about HIV/AIDS infection?" "Do you know where to get tested to see if you are infected with the HIV/AIDS virus?" "Do you know how to keep from getting the HIV/AIDS virus?" and "Have you ever talked about HIV/AIDS with a friend?"

When students attending SDA boarding schools in Ethiopia were asked, "Should students your age be taught about HIV/AIDS infection in school?" more than 
$90 \%$ in all levels of years of attendance indicated "yes." Those who have attended from 2-6 years, however, had the highest percentage (95.5\%) with those attending from 7-10 years having the lowest percentage $(92.7 \%)\left(\chi^{2}=17.421, d f=6, p=.008\right)$. Although there is statistical difference, there is no clear trend.

The second question in which there was significant statistical difference is when students were asked, "Have you ever talked abut HIV/AIDS with your parents or some other adult in your family?" More than $50 \%$ of all students indicated that they had. The highest percentage of students attending SDA schools that indicated "yes" were the $2-6$ years $(60.0 \%)$ compared to the lowest group, those in attendance for only $0-1$ years $\left(\chi^{2}=17.941, d f=6, p=.006\right)$. There is an upward trend based on years of attendance in SDA schools and the relationship to those who have talked with their parent or adult family member about HIV/AIDS.

Fewer than $50 \%$ of students in the four levels of years of attendance believed that a student with HIV/AIDS infection should be allowed to go to their school $\left(\chi^{2}=5.650, d f=6, p=464\right)$ and fewer than $60 \%$ of all students indicated that they would be willing to be in the same class as another student with HIV/AIDS infection $\left(\chi^{2}=11.234\right.$, $d f=6, p=.081)$.

Only $50-60 \%$ of students from all years of attendance indicated that they know where to get good information about HIV/AIDS $\left(\chi^{2}=7.718, d f=6, p=.259\right)$ or where to get tested for HIV/AIDS $\left(\left(\chi^{2}=1.695, d f=6, p=.946\right)\right.$. It was interesting to note that almost $90 \%$ of all respondents $\left(\chi^{2}=2.091, d f=6, p=.991\right)$ indicated that they know how to keep from getting the HIV/AIDS virus. More than $70 \%$ of all years of attendance groups 
Table 17. Chi-square Results of HIV/AIDS-Related Belief Responses Among Academy Students in Relationship to Length of Attendance at Seventh-day Adventist Schools.

\begin{tabular}{|l|c|c|}
\hline Belief & \multicolumn{1}{|c|}{ Item } & Prob $^{\mathrm{a}}$ \\
\hline $\begin{array}{l}\text { 7. Should students your age be taught about HIV/AIDS } \\
\text { infection in school? }\end{array}$ & 17.421 & $.008^{* *}$ \\
$\begin{array}{l}\text { 8. Have you been taught about HIV/AIDS infection in } \\
\text { school? }\end{array}$ & 12.456 & .053 \\
$\begin{array}{l}\text { 9. Should a student with HIV/AIDS infection be allowed to } \\
\text { go to your school? }\end{array}$ & 5.650 & .464 \\
$\begin{array}{l}\text { 10. Would you be willing to be in the same class with a } \\
\text { student with HIV/AIDS infection? }\end{array}$ & 11.234 & .081 \\
$\begin{array}{l}\text { 11. Do you know where to get good information about } \\
\text { HIV/AIDS infection? }\end{array}$ & 7.718 & .259 \\
$\begin{array}{l}\text { 12. Do you know where to get tested to see if you are } \\
\text { infected with the HIV/AIDS virus? }\end{array}$ & 1.695 & .946 \\
$\begin{array}{l}\text { 13. Do you know how to keep from getting the HIV/AIDS } \\
\text { virus? }\end{array}$ & 2.091 & .911 \\
$\begin{array}{l}\text { 14. Have you ever talked about HIV/AIDS with a friend? } \\
\text { 15. Have you ever talked about HIV/AIDS with your parents } \\
\text { or some other adult in your family? }\end{array}$ & 17.941 & $.006^{* *}$ \\
\hline
\end{tabular}

${ }^{2} d f=6$.

${ }^{*} p \leq 0.05{ }^{* *} p \leq 0.01$. 
indicated that they have talked with a friend about HIV/AIDS $\left(\chi^{2}=6.318, d f=6, p=.388\right)$, whereas fewer than $60.0 \%$ responded that they had talked with their parents or another adult family member $\left(\chi^{2}=17.941, d f=6, p=.006\right)$.

In summary, it can be stated that the belief level in regard to HIV/AIDS of students attending SDA boarding schools in Ethiopia reveals no clear trend that there is a difference based on years of attendance at SDA schools.

\section{Research Question 17}

Is there a relationship between years of attendance at Seventh-day Adventist boarding schools and knowledge level in relation to HIV/AIDS among students attending Seventh-day Adventist boarding schools in Ethiopia?

Ninth- through 12th-grade students attending Seventh-day Adventist boarding schools in Ethiopia answered a self-report survey on HIV/AIDS to identify if there was a relationship between length of stay at Seventh-day Adventist schools and HIV/AIDSrelated knowledge. On the survey, students were given a choice of four levels of years in attendance: $0-1$ years, $2-6$ years, $7-10$ years, and 11 years or more.

A Chi-square test of independence was performed on each of the 19 questions which dealt with HIV/AIDS-related knowledge. Based on a 0.05 probability level, there were 12 statistically significant differences in the questions. The results can be seen in Table 18 and Table 35 (in Appendix A).

Students attending SDA boarding schools for 7-10 years had the least highest percentage for answering correctly the following questions: "Can a person get HIV/AIDS infection from holding hands with someone?" $(75.8 \%)\left(\chi^{2}=17.480, d f=6, p=.008\right)$, "Can 
Table 18. Chi-square Results of HIV/AIDS-Related Knowledge Responses Among Academy Students in Relationship to Length of Attendance at Seventh-day Adventist Schools

\begin{tabular}{|c|c|c|c|}
\hline Kno & wledge & $\chi^{2}$ & Prob $^{a}$ \\
\hline & $\begin{array}{l}\text { Can a person get HIV/AIDS infection from holding hands } \\
\text { with someone? }\end{array}$ & 17.480 & $.008 * *$ \\
\hline 17. & $\begin{array}{l}\text { Can a person get HIV/AIDS infection from sharing needles } \\
\text { used to inject drugs? }\end{array}$ & 17.220 & $.009 * *$ \\
\hline 18. & $\begin{array}{l}\text { Can a person get HIV/AIDS from being bitten by a } \\
\text { mosquito which has fed on a person with AIDS? }\end{array}$ & 13.336 & $.038 *$ \\
\hline 19. & Can a person get HIV/AIDS from donating blood? & 5.981 & .425 \\
\hline 20. & $\begin{array}{l}\text { Can a person get HIV/AIDS from having blood drawn with a } \\
\text { sterile needle? }\end{array}$ & 18.723 & $.005^{* *}$ \\
\hline 21. & $\begin{array}{l}\text { Can a person get HIV/AIDS infection by wearing clothes } \\
\text { used by someone who has the AIDS virus? }\end{array}$ & 23.898 & $.001^{* *}$ \\
\hline 22. & $\begin{array}{l}\text { Can a person get HIV/AIDS infection from having sexual } \\
\text { intercourse without using a condom? }\end{array}$ & 3.554 & .737 \\
\hline 23. & $\begin{array}{l}\text { Can a person get HIV/AIDS infection from being in the same } \\
\text { class with a student who has AIDS/HIV infection? }\end{array}$ & 10.257 & .114 \\
\hline & $\begin{array}{l}\text { Can you tell if people are infected with the AIDS virus } \\
\text { (HIV) just by looking at them? }\end{array}$ & 27.997 & $.000^{* *}$ \\
\hline 25 . & $\begin{array}{l}\text { Can a person who has the AIDS virus (HIV) infect someone } \\
\text { else during sexual intercourse? }\end{array}$ & 6.716 & .667 \\
\hline & $\begin{array}{l}\text { Can a pregnant woman who has the AIDS virus (HIV) infect } \\
\text { Her unborn baby with the virus? }\end{array}$ & 18.751 & $.005^{* *}$ \\
\hline 27. & Is there a cure for HIV/AIDS infection? & 9,786 & .134 \\
\hline
\end{tabular}


Table 18--Continued.

\begin{tabular}{|l|c|c|}
\hline Knowledge & \multicolumn{1}{|c|}{ Item } & Prob $^{\mathbf{a}}$ \\
\hline $\begin{array}{l}\text { 28. Is it true that only homosexual men can get the HIV/AIDS } \\
\text { infection? }\end{array}$ & 22.066 & $.001^{* *}$ \\
29. Can people reduce their chances of becoming infected with the \\
$\begin{array}{l}\text { HIV/AIDS virus by not having any kind of sexual } \\
\text { intercourse? }\end{array}$ & 6.172 & .404 \\
$\begin{array}{l}\text { 30. Can people reduce their chances of becoming infected with the } \\
\text { AIDS virus (HIV) by using condoms (rubbers) during sexual } \\
\text { intercourse? }\end{array}$ & 33.252 & $.000^{* *}$ \\
$\begin{array}{l}\text { 31. Can people reduce their chances of becoming infected with the } \\
\text { AIDS virus (HIV) by not having any kind of sexual } \\
\text { intercourse with a person who has injected (shot up)drugs? }\end{array}$ & 9.495 & .148 \\
$\begin{array}{l}\text { 32. Can people reduce their chances of becoming infected with the } \\
\text { AIDS virus (HIV) by taking birth control pills? }\end{array}$ & 17.096 & $.009^{* *}$ \\
$\begin{array}{l}\text { 33. Can AIDS be cured if it is diagnosed early? } \\
\begin{array}{l}\text { 34. Can you catch the AIDS virus by sharing needles/syringes } \\
\text { with someone who has the AIDS virus? }\end{array}\end{array}$ & 13.390 & $.037^{*}$ \\
\hline
\end{tabular}

a $d f=6$.

${ }^{*} p \leq 0.05$. ** $p \leq 0.01$. 
a person get HIV/AIDS infection from sharing needles used to inject drugs?" (84.5\%) $\left(\chi^{2}=17.220, d f=6, p=.009\right)$, "Can a person get HIV/AIDS from being bitten by a mosquito which has fed on a person with AIDS?" $(35.2 \%)\left(\chi^{2}=13.336, d f=6, p=.038\right)$, "Can a person get HIV/AIDS from having blood drawn with a sterile needle?"(55.7\%) $\left(\chi^{2}=18.723, p=6, p=.005\right)$, "Can a person get HIV/AIDS infection by wearing clothes used by someone who has the AIDS virus?" $(65.8 \%)\left(\chi^{2}=23.89, d f=6, p=.001\right)$, "Can you tell if people are infected with the HIV/AIDS virus just by looking at them?" (57.5\%) $\left(\chi^{2}=27.997, d f=6, p=000\right)$, "Can a pregnant woman who has the AIDS virus (HIV) infect her unborn baby with the virus?" $(83.5 \%)\left(\chi^{2}=18.751, d f=6, p=.005\right)$, "Is it true that only homosexual men can get the HIV/AIDS infection?" $(35.4 \%)\left(\chi^{2}=22.066, d f=6, p=.001\right)$, "Can people reduce their chances of becoming infected with the AIDS virus (HIV) by taking birth control pills?" $(74.9 \%)\left(\chi^{2}=17.096, d f=6, p=.009\right)$, "Can AIDS be cured if it is diagnosed early?" $(67.6 \%)\left(\chi^{2}=17.257, d f=6, p=.008\right)$, and "Can you catch the AIDS virus by sharing needles/syringes with someone who has the AIDS virus?" (76.7\%) $\left(\chi^{2}=13.390, d f=6, p=.037\right)$.

In the one other statistically significant question, "Can people reduce their chances of becoming infected with the AIDS virus (HIV) by using condoms (rubbers) during sexual intercourse?" those students attending SDA boarding schools for more than 11 years had the lowest percentage for the correct answer (53.1\%) with students attending from $7-10$ years having the second lowest $(64.8 \%)$ percentage $\left(\chi^{2}=33.252\right.$, $d f=6, p=.000$ ).

In comparing the correct answers to all 12 statistically significant questions, six questions were answered correctly with the highest percentage by those in attendance for 
2-6 years, four for those with 11 or more years in attendance, and three for those in attendance $0-1$ years. It should be noted that in question 16 , both $0-1$ years of attendance and 2-6 years had the same high percentage of 85.4 . Therefore, we can see that eight statistically significant questions were answered correctly by those students attending SDA schools for fewer than 7 years, while only four questions were answered correctly by those in attendance for more than 11 years.

In summary, it can be stated that there is a trend which shows that students attending Seventh-day Adventist schools for longer periods of time (7-10 years) have a less HIV/AIDS-related knowledge than do those who have attended for shorter periods of time.

\section{Research Question 18}

Is there a relationship between length of attendance at Seventh-day Adventist schools and sexual behavior in relation to HIV/AIDS among students attending Seventhday Adventist boarding schools in Ethiopia?

Ninth- through 12th-grade students attending Seventh-day Adventist boarding schools in Ethiopia answered a self-report survey on HIV/AIDS to identify if there was a relationship between length of stay at Seventh-day Adventist schools and HIV/AIDS related sexual behavior. On the survey, students were given a choice of four levels of years in attendance: 0-1 years, 2-6 years, 7-10 years, and 11 years or more. A Chi-square test of independence was performed on each of the four questions which dealt with HIV/AIDS-related behavior. Based on a 0.05 probability level there was no statistically 
significant difference in any of the questions. The results can be seen in Table 19 and Table 36 (in Appendix A)

Table 19. Chi-square Results of HIV/AIDS-Related Behavior Responses Among Academy Students in Relationship to Length of Attendance at Seventh-day Adventist Schools

\begin{tabular}{|l|c|c|}
\hline Behavior & $\chi^{2}$ & Prob $^{\mathrm{a}}$ \\
\hline $\begin{array}{l}\text { 35. With how many people have you had any kind of sexual } \\
\text { intercourse in your life? }\end{array}$ & 14.420 & .275 \\
$\begin{array}{l}\text { 36. With how many people have you had any kind of sexual } \\
\text { intercourse in the last year? }\end{array}$ & 11.595 & .479 \\
$\begin{array}{l}\text { 37. How old were you the first time you had any kind of } \\
\text { sexual intercourse? }\end{array}$ & 7.930 \\
$\begin{array}{l}\text { 38. When you have any kind of sexual intercourse, how } \\
\text { often is a condom (rubber) used? }\end{array}$ & 6.636 & .881 \\
\hline
\end{tabular}

${ }^{a} d f=12$.

${ }^{*} p \leq 0.05$. ${ }^{* *} p \leq 0.01$.

\section{Research Question 19}

Is there a relationship between the extent to which students talk to their

parents or another adult and sexual behavior in relation to HIVIAIDS among students attending Seventh-day Adventist boarding schools in Ethiopia?

Ninth-through 12th-grade students attending Seventh-day Adventist boarding schools in Ethiopia answered a self-report survey on HIV/AIDS to identify if there was a relationship between the extent to which students talk to their parents about AIDS and their sexual behavior. 
A Chi-square test of independence was performed on question 15 which asked, "Have you ever talked about HIV/AIDS with your parents or some other adult in your family?" in relation to the four HIV/AIDS sexual behavior questions. Based on a 0.05 probability level, there were statistically significant differences in all four of the questions. The results can be seen in Table 20 and Table 37 (in Appendix A).

Table 20. Chi-square Results of HIV/AIDS-Related Behavior Responses Among Academy Students in Relationship to Extent to Which Students Talk to Their Parents

\begin{tabular}{|l|c|c|}
\hline Behavior & \multicolumn{1}{|c|}{$\chi^{2}$} & Prob $^{\mathbf{a}}$ \\
\hline $\begin{array}{l}\text { 35. With how many people have you had any kind of } \\
\text { sexual intercourse in your life? }\end{array}$ & 15.785 & $.046^{*}$ \\
$\begin{array}{l}\text { 36. With how many people have you had any kind of } \\
\text { sexual intercourse in the last year? }\end{array}$ & 20.441 & $.009^{* *}$ \\
$\begin{array}{l}\text { 37. How old were you the first time you had any kind of } \\
\text { sexual intercourse? }\end{array}$ & 28.326 & $.000^{* *}$ \\
$\begin{array}{l}\text { 38. When you have any kind of sexual intercourse, how } \\
\text { often is a condom (rubber) used? }\end{array}$ & 16.264 & $.039^{*}$ \\
${ }^{2} d f=12$. & & \\
${ }^{*} p \leq 0.05 . * * p \leq 0.01$. & & \\
\hline
\end{tabular}

When students were asked the last four questions, "With how many people have you had any kind of sexual intercourse in your life?" $\left(\chi^{2}=15.875, d f=8, p=.046\right)$, "With how many people have you had any kind of sexual intercourse in the last year?" $\left(\chi^{2}=20.441, d f=8, p=.009\right)$, "How old were you the first time you had any kind of sexual intercourse?" $\left(\chi^{2}=28.326, d f=8, p=.000\right)$, and "When you have any kind of sexual 
intercourse, how often is a condom used?" $\left(\chi^{2}=16.264, d f=8, p=.039\right), 59-60 \%$ of those who indicated they did communicate with a parent or adult recorded in all four of the questions that they have never had any sexual intercourse. However, of those who responded to having no communication, only $36-37 \%$ indicated that they have had no sexual relationships.

In summary, it can be said that there is a decreased incidence in sexual intercourse among students who do communicate with a parent or another adult family member. Over-generalization should be avoided, however, as there is no clear trend to indicate that the number of sexual partners decreases, onset of sexual activity increases with age, or condom usage increases in relation to communication with parent or other adult family member.

\section{Summary}

This study examined HIV/AIDS-related belief, knowledge, and sexual behavior of secondary students in three selected Seventh-day Adventist schools Ethiopia. This study also examined the relationships between these variables and grade levels, gender, age, SDA affiliation, and years in SDA schools. There were 14 research questions that the study provided statistics and information on. Table 21 summarizes the results of this study.

The first research question was to identify the level of belief towards HIV/AIDS among students attending Seventh-day Adventist boarding schools in Ethiopia. A majority of the students (57\%-94\%) believed that students should be taught about AIDS in schools, that students who have been infected with AIDS should be allowed in 
Table 21. Summary of Research Questions 2 through 7

\begin{tabular}{|c|c|c|c|c|c|c|}
\hline \multirow[t]{2}{*}{ Belief } & \multicolumn{6}{|c|}{ Independent Variables* } \\
\hline & A & $B$ & $\mathrm{C}$ & $\mathrm{D}$ & $\mathrm{E}$ & $\mathrm{F}$ \\
\hline 7. Should students be taught about HIV/AIDS? & & $x$ & & & $\mathrm{X}$ & \\
\hline $\begin{array}{l}\text { 8. Have you been taught about HIV/AIDS in } \\
\text { school? }\end{array}$ & $\mathrm{X}$ & $\mathrm{X}$ & $\mathrm{X}$ & $\mathrm{x}$ & & \\
\hline $\begin{array}{l}\text { 9. Should a student with HIV/AIDS be allowed to } \\
\text { go to your school? }\end{array}$ & $\mathrm{X}$ & $\mathrm{X}$ & & $\mathrm{X}$ & & \\
\hline $\begin{array}{l}\text { 10. Are they willing to attend the same class with } \\
\text { a student who has HIV/AIDS? }\end{array}$ & & & $\mathrm{x}$ & $\mathrm{X}$ & & \\
\hline $\begin{array}{l}\text { 11. Do they know where to get good information } \\
\text { about HIV/AIDS? }\end{array}$ & $\mathrm{X}$ & & & & & \\
\hline $\begin{array}{l}\text { 12. Do they know where to get tested for } \\
\text { HIV/AIDS? }\end{array}$ & & & & & & \\
\hline $\begin{array}{l}\text { 13. Do they know how to keep from getting } \\
\text { HIV/AIDS infection? }\end{array}$ & & $\mathrm{X}$ & & & & \\
\hline $\begin{array}{l}\text { 14. Have they ever talked about HIV/AIDS with a } \\
\text { friend? }\end{array}$ & $X$ & $\mathrm{X}$ & $\mathrm{X}$ & $\mathrm{X}$ & & \\
\hline $\begin{array}{l}\text { 15. Have they talked about HIV/AIDS with } \\
\text { parent/adult? }\end{array}$ & & $X$ & $\mathrm{X}$ & $\mathrm{X}$ & $X$ & \\
\hline $\begin{array}{l}\text { 16. Can a person get HIV/AIDS from holding } \\
\text { hands? }\end{array}$ & & $\mathrm{X}$ & & & $\mathrm{X}$ & \\
\hline $\begin{array}{l}\text { 17. Can a person get HIV/AIDS from sharing } \\
\text { needles? }\end{array}$ & & & & & $\mathrm{X}$ & \\
\hline 18. Can a person get HIV/AIDS from mosquitoes? & $\mathrm{X}$ & $\mathrm{X}$ & $\mathrm{X}$ & & $\mathrm{X}$ & \\
\hline $\begin{array}{l}\text { 19. Can a person get HIV/AIDS from donating } \\
\text { blood? }\end{array}$ & $\mathrm{X}$ & & & $\mathrm{X}$ & & \\
\hline $\begin{array}{l}\text { 20. Can a person get HIV/AIDS from having a } \\
\text { blood test? }\end{array}$ & $\mathrm{x}$ & $x$ & & $\mathrm{X}$ & $\mathrm{X}$ & \\
\hline $\begin{array}{l}\text { 21. Can a person get HIV/AIDS from sharing } \\
\text { Clothes? }\end{array}$ & & & & & $\mathrm{X}$ & \\
\hline
\end{tabular}


Table 21--Continued.

\begin{tabular}{|c|c|c|c|c|c|c|}
\hline \multirow[t]{2}{*}{ Belief } & \multicolumn{6}{|c|}{ Independent Variables* } \\
\hline & A & B & $\mathrm{C}$ & D & $\mathrm{E}$ & $\mathrm{F}$ \\
\hline $\begin{array}{l}\text { 22. Can a person get HIV/AIDS from having sexual } \\
\text { intercourse without a condom? }\end{array}$ & $\mathrm{X}$ & $\mathrm{X}$ & & & & \\
\hline $\begin{array}{l}\text { 23. Can a person get HIV/AIDS from being in the } \\
\text { same class with someone who has AIDS? }\end{array}$ & $\mathrm{X}$ & & & & & \\
\hline $\begin{array}{l}\text { 24. Can you tell if people are infected with the } \\
\text { AIDS virus by looking at them? }\end{array}$ & $\mathrm{X}$ & $\mathrm{X}$ & & & $\mathrm{X}$ & \\
\hline $\begin{array}{l}\text { 25. Can a person who has AIDS infect someone } \\
\text { else during intercourse? }\end{array}$ & & & & & & \\
\hline $\begin{array}{l}\text { 26. Can a pregnant woman who has AIDS infect } \\
\text { her unborn baby? }\end{array}$ & $\mathrm{X}$ & $\mathrm{X}$ & & & $\mathrm{X}$ & \\
\hline 27. Is there a cure for HIV/AIDS infection? & & & & $\mathrm{x}$ & & \\
\hline $\begin{array}{l}\text { 28. Is it true that only homosexual men can get } \\
\text { HIV/AIDS? }\end{array}$ & $\mathrm{X}$ & & $\mathrm{X}$ & $\mathrm{X}$ & $\mathrm{X}$ & \\
\hline $\begin{array}{l}\text { 29. Can people reduce their chances of getting } \\
\text { HIV/AIDS by not having any kind of sexual } \\
\text { intercourse? }\end{array}$ & & & & & & \\
\hline $\begin{array}{l}\text { 30. Can people reduce their chances of becoming } \\
\text { infected with AIDS by using condoms during } \\
\text { Sexual intercourse? }\end{array}$ & & & & $X$ & $X$ & \\
\hline $\begin{array}{l}\text { 31. Can people reduce their chances of getting AIDS } \\
\text { by not having sexual intercourse with a person } \\
\text { Who has injected drugs? }\end{array}$ & $\mathrm{X}$ & & & & & \\
\hline
\end{tabular}


Table 21--Continued.

\begin{tabular}{|c|c|c|c|c|c|c|}
\hline \multirow[t]{2}{*}{ Belief Item } & \multicolumn{6}{|c|}{ Independent Variables* } \\
\hline & A & $\mathrm{B}$ & $\mathrm{C}$ & D & $\mathrm{E}$ & $\mathbf{F}$ \\
\hline $\begin{array}{l}\text { 32. Can people reduce their chances of becoming infected with } \\
\text { AIDS by taking birth control pills? }\end{array}$ & & & & & $\mathbf{X}$ & \\
\hline 33. Can AIDS be cured if it is diagnosed early? & $\mathbf{X}$ & & & & $\mathbf{X}$ & \\
\hline $\begin{array}{l}\text { 34. Can you catch AIDS by sharing needles/syringes with } \\
\text { someone who has the AIDS virus? }\end{array}$ & $\mathbf{x}$ & & & $\mathbf{X}$ & $\mathbf{x}$ & \\
\hline 35. How many people have you had sexual intercourse with? & & $\mathbf{X}$ & $\mathbf{X}$ & & & $\mathbf{X}$ \\
\hline $\begin{array}{l}\text { 36. How many people have you had sexual intercourse with in } \\
\text { the last year? }\end{array}$ & $\mathbf{X}$ & $\mathbf{X}$ & $\mathbf{X}$ & & & $\mathbf{X}$ \\
\hline 37. How old were you the first time you had sexual intercourse? & $\mathbf{X}$ & $\mathbf{X}$ & $\mathbf{X}$ & & & $\mathbf{X}$ \\
\hline 38. How often do you use a condom during sexual intercourse? & $\mathbf{X}$ & $\mathbf{X}$ & $\mathbf{X}$ & & & $\mathbf{X}$ \\
\hline
\end{tabular}

Note. $\mathrm{X}=$ statistically significant items.

* Independent variables are: $A=$ Grade Level; $B=$ Age; $C$ - Gender; D = SDA Affiliation; $\mathrm{E}=$ Length of Attending SDA Schools; $\mathrm{F}=$ Communicating with Parents. 
schools, and that they would be willing to be in the same class with these infected students.

A majority of these students also know where to get information about AIDS; how to keep from getting AIDS; and have talked with parents of other adults about HIV/AIDS.

The second research question sought to identify the knowledge level regarding HIV/AIDS among students attending Seventh-day Adventist boarding schools in Ethiopia. Most students (60\%-90\%) have accurate knowledge about AIDS. Somewhat disturbing is that almost half of the students believed that one can get AIDS by being bitten by mosquitoes, by donating blood, and that only homosexuals can get AIDS.

The third research question sought to identify the sexual behaviors in relation to HIV/AIDS among students attending Seventh-day Adventist boarding schools in Ethiopia. About $25 \%$ of the students were sexually active. Of these students only $30 \%$ always use condoms.

The fourth research question sought to identify the relationship between grade levels and beliefs towards HIV/AIDS among students attending Seventh-day Adventist boarding schools in Ethiopia. Significant relationships were found between grade levels and (1) having been taught about AIDS in school, (2) HIV-infected students being allowed in school, (3) knowing where to get information about AIDS, and (4) having talked with an adult about HIV/AIDS virus. Generally, the higher the grade levels, the more positive their beliefs.

The fifth research question sought to identify the relationship between grade levels and knowledge level regarding HIV/AIDS among students attending Seventh-day 
Adventist boarding schools in Ethiopia. There were 19 HIV/AIDS related knowledge questions. Grade levels were significantly related to 11 of these (57.89\%) questions. Generally, the proportion of students correctly answering these items increased with grade levels.

The sixth research question was to identify the relationship between grade levels and sexual behavior in relation to HIV/AIDS among students attending Seventh-day Adventist boarding schools in Ethiopia. Sexual activity and behavior are related to grade levels. Proportionally, more sexually active students are in the upper grade levels.

The seventh research question sought to identify the relationship between age and beliefs towards HIV/AIDS among students attending Seventh-day Adventist boarding schools in Ethiopia. Six of the nine HIV/AIDS -related belief questions were significantly related to age levels. Age levels were related to being taught about HIV/AIDS, infected students being allowed in schools, knowing how not to get AIDS, and having talked with a friend, parents or other adults about AIDS.

The eighth research question sought to identify the relationship between age and knowledge level regarding HIV/AIDS among students attending Seventh-day Adventist boarding schools in Ethiopia. Seven of the 19 HIV/AIDS-related knowledge questions were significantly related to age level. Significant relationships were found between age levels and getting AIDS from (1) holding hands with someone, (2) being bitten by mosquitoes, (3) having blood drawn with a sterile needle, (4) having sex without condoms, (5) being in a class with infected students, and (6) infected persons having sex with. Age was also related to the knowledge of whether pregnant women who have 
AIDS can infect their unborn babies. Generally, knowledge tended to be more accurate among older students.

The ninth research question sought to determine the relationships between age and sexual behavior in relation to HIV/AIDS among students attending Seventh-day Adventist boarding schools in Ethiopia. Age is significantly related to sexual behavior and practices.

The 10th research question sought to determine the relationship between gender and beliefs towards HIV/AIDS among students attending Seventh-day Adventist boarding schools in Ethiopia. Gender is significantly related to (1) beliefs that students should be taught about HIV/AIDS, (2) being willing to be in the same class as someone who has AIDS, and (3) having talked with a friend or parents or other adults about HIV/AIDS. Proportionally, more females have been taught about AIDs and have talked with parents or other adults about AIDS, but more males have talked with friends about AIDS and are more willing to be in classes with AIDS-infected individuals.

The 11 th research question sought to identify the relationship between gender and knowledge levels in relation to HIV/AIDS among students attending Seventh-day Adventist boarding schools in Ethiopia. There were 19 HIV/AIDS-related knowledge questions. Two of these (10.52\%) were significantly related to gender. A larger proportion of females incorrectly answered that one can get AIDS by being bitten by mosquitoes and that only homosexuals can get AIDS.

The 12th research question sought to identify the relationship between gender and sexual behavior in relation to HIV/AIDS among students attending Seventh-day Adventist boarding schools in Ethiopia. Gender is significantly related to sexual behavior 
and practices. Males tended to be more sexually active and more likely not to use condoms during sexual intercourse.

The 13 th research question sought to identify the relationship between Seventh-day Adventist religious affiliation and belief towards HIV/AIDS among students attending Seventh-day Adventist boarding schools in Ethiopia. There were nine HIV/AIDS-related belief questions. Five of these $(55.55 \%)$ were statistically related to religious affiliation. Compared to non-Seventh-day Adventists, proportionally more Adventist students (1) have been taught about AIDS, (2) agreed that infected students should be allowed in school, (3) are willing to be in classes with infected students, and (4) have talked with a friend, parent, or other adults about AIDS.

Significant relationships between religious affiliation and 6 of the 19 knowledge questions were found. Significantly larger proportions of Seventh-day Adventist students had the incorrect belief that (1) people can get AIDS by donating blood, (2) by having blood drawn with sterile needles, (3) there is a cure for AIDS, and (4) only homosexuals can get AIDS. A smaller proportion of SDA students also believed that using condoms during sexual intercourse can reduce the chances of getting AIDS.

The 15 th research question sought to identify the relationship between Seventh-day Adventist religious affiliation and sexual behavior in relation to HIV/AIDS among students attending Seventh-day Adventist boarding schools in Ethiopia. Religious affiliation was not statistically related to sexual behavior and practices. About $30 \%$ of both SDA and non-SDA students were sexually active.

The 16 th research question sought to identify the relationship between attendance at Seventh-day Adventist schools and belief towards HIV/AIDS among 
students attending Seventh-day Adventist boarding schools in Ethiopia. While $90 \%$ or more of the students agree that they should be taught about AIDS in school, this proportion appears to slightly decrease as students have spent more time in SDA schools. Perhaps this can be partly explained by an increasing proportion of students who talked to their parents or other adults in their family $(50 \%-60 \%)$ about AIDS.

The 17 th research question sought to identify the relationship between attendance at Seventh-day Adventist schools and knowledge level in relation to HIV/AIDS among students attending Seventh-day Adventist boarding schools in Ethiopia. Twelve of 19 knowledge-related questions were significantly related to length of years in SDA schools. In general, knowledge tended to be more accurate as students spent more time in SDA schools.

The 18 th research question sought to identify the relationship between attendance at Seventh-day Adventist schools and sexual behavior in relation to HIV/AIDS among students attending Seventh-day Adventist boarding schools in Ethiopia. No significant relationships were found between length of attendance at SDA schools and sexual behavior and practices.

The 19th research question sought to identify the relationship between the extent to which students talk to their parents or another adult and sexual behavior in relation to HIV/AIDS among students attending Seventh-day Adventist boarding schools in Ethiopia. Sexual behavior is significantly related to whether or not they have talked with their parents or other adults in their family about HIV/AIDS. Those who have talked with their parents or other adults about AIDS tended to be less sexually active. Those 
who were sexually active tended to have had their first sexual experience at an older age and were more likely to use condoms during sexual intercourse. 
CHAPTER V

\section{SUMMARY, DISCUSSION, CONCLUSIONS, AND RECOMMENDATIONS}

\section{Introduction}

The purpose of this study was to examine the HIV/AIDS-related beliefs, knowledge, and sexual behavior of students attending Seventh-day Adventist secondary boarding schools in Ethiopia. This chapter presents the summary, discussion, conclusions, and recommendations for further research.

\section{Purpose of the Study}

The purpose of this study was to investigate the beliefs and knowledge about AIDS/HIV and sexual behavior of students attending three Seventh-day Adventist secondary schools in Ethiopia. This study also examined the relationships between these variables (beliefs, knowledge, and sexual behavior) and grade levels, age, gender, SDA affiliation, and length of attendance in SDA schools.

\section{Review of Literature}

Acquired Immunodeficiency Syndrome (AIDS) (Dixon, 1994) is caused by the Human Immunodeficiency Virus (HIV) (LaPierre, 1991). AIDS is a life-threatening disease that weakens and ultimately destroys an infected person's immune system. 
AIDS was first discovered in the United States in 1981 (Dixon, 1994). Since the early 1980s, more than 40 million individuals have contracted HIV, and almost 12 million have died. More than $90 \%$ of all worldwide AIDS cases in 1997 were found in developing countries. Of the developing countries, Sub-Saharan Africa is the region with the fastest-moving AIDS epidemic and is now thought to have at least two-thirds (68\%) of the total world number of people infected with HIV (Kerkhoven, 1998).

The first AIDS case in Ethiopia was reported in February 1986. According to the Ethiopian Ministry of Health (1996), it was estimated that by 1993 the adult HIV prevalence rate had increased to $3.2 \%$. By 1996 , this rate had already increased to $5.2 \%$ or 1.7 million. The World Health Organization (WHO) estimated that for every 19 adults (of the total adult population), 1 is infected (W/yohannes, 1996).

HIV is transmitted by three main modes: (1) sexually-exchange of HIVinfected body fluids such as semen, vaginal secretions, or blood during sexual intercourse, (2) blood-receiving blood transfusions intravenously, sharing of syringes and needles, using sharp, non-sterilized instruments, organ transplants from HIV-infected people, and (3) vertical-from HIV-infected mother to her unborn child during delivery, or after, in breast milk. HIV is not transmitted through casual contact such as holding hands, kissing, or sharing the same room, nor is it transmitted through insect bites such as mosquitoes or bed bugs (Kariuki, 1998).

Current literature reveals that some studies have been done on adolescent knowledge, beliefs, and behaviors in regard to HIV/AIDS in Africa (Kariuki, 1998; Tshimika, 1991). It has also been noted that few studies have been done in Ethiopia as a whole. According to Mr. Abebe Disasa, Education Director of the Seventh-day Adventist 
Church in Ethiopia, none have been done in the Ethiopian Seventh-day Adventist boarding schools. It was noted from previous studies, however, that the vast majority of students do have some knowledge in regard to HIV/AIDS. Regardless of their knowledge of HIV/AIDS, it was seen that many young people are sexually active and have their sexual debut at very young ages (Fantahan \& Chala, 1996; Tshimika, 1991).

\section{Methodology}

The objective of the study was to collect information on HIV/AIDS-related beliefs, knowledge, and sexual behavior of academy students attending Seventh-day Adventist boarding schools in Ethiopia. The survey consisted of a 38-question, multiplechoice-answer questionnaire. This study was descriptive research to assess the dependent variables of HIV/AIDS-related beliefs, knowledge, and selected sexual behavioral practices that could predispose an adolescent to HIV infection.

The subjects involved in the survey were students in Grades 9-12 enrolled in Seventh-day Adventist boarding academies in the second semester of 1998 in Ethiopia. Completing the survey were 1,144 students, yielding a $89.375 \%$ response rate of total enrollment.

The AIDS Survey for Students was the instrumentation used for data collection in this study. It was originally developed through the Centers for Disease Control to assist 24 state and local departments of education in assessing HIV-related beliefs, knowledge, and behaviors among high-school students in the United States.

The independent variables measured were grade level, age, gender, SDA religious affiliation, length of attendance at SDA school, and communication with 
parent/adult. Descriptive data of the subjects were obtained by performing a frequency distribution. Statistical procedures using Chi-square were used to test the research hypotheses. Statistical significance was set at alpha $=0.05$. The Statistical Packages for the Social Science (SPSS) was used for data analysis.

\section{Results of the Study}

This study examined HIV/AIDS-related beliefs, knowledge, and sexual behavior of secondary students in the three Seventh-day Adventist boarding schools in Ethiopia. It also examined the relationships between these variables and grade levels, gender, age, SDA affiliation, and years in SDA schools. Fourteen research questions from the study generated statistics and information.

The first research question sought to identify the level of belief towards HIV/AIDS among students attending Seventh-day Adventist boarding schools in Ethiopia. A majority of the students (57\%-94\%) believed that students should be taught about AIDS in schools, that students who have been infected with AIDS should be allowed in schools, and that they would be willing to be in the same class with these infected students. A majority of students also know where to get information about AIDS; how to keep from getting AIDS; and have talked with parents or other adults about HIV/AIDS.

The second research question sought to identify the knowledge level regarding HIV/AIDS among students attending Seventh-day Adventist boarding schools in Ethiopia. Most students (60\%-90\%) have accurate knowledge about AIDS. Somewhat disturbing is that almost half of the students believed that one can get AIDS by being bitten by mosquitoes, by donating blood, and that only homosexuals can get AIDS. 
The third research question sought to identify sexual behaviors in relation to HIV/AIDS among students attending Seventh-day Adventist boarding schools in Ethiopia. About $25 \%$ of the students were sexually active. Of these students, only $30 \%$ always use condoms.

The fourth research question sought to identify the relationship between grade levels and beliefs towards HIV/AIDS among students attending Seventh-day Adventist boarding schools in Ethiopia. Significant relationships were found between grade levels and (1) having been taught about AIDS in school, (2) HIV-infected students being allowed in school, (3) knowing where to get information about AIDS, and (4) having talked with a parent/adult about HIV/AIDS. Generally, the higher the grade levels, the more positive their beliefs.

The fifth research question sought to identify the relationship between grade levels and HIV/AIDS knowledge level among students attending Seventh-day Adventist boarding schools in Ethiopia. There were 19 HIV/AIDS-related knowledge questions. Grade levels were significantly related to 11 of these (57.89\%) questions. Generally, the proportion of students correctly answering these items increased with grade levels.

The sixth research question sought to identify the relationship between grade levels and sexual behavior in relation to HIV/AIDS among students attending Seventh-day Adventist boarding schools in Ethiopia. Sexual activity and behavior are related to grade levels. Proportionally, more sexually active students are in the upper grade levels.

The seventh research question sought to identify the relationship between age and beliefs towards HIV/AIDS among students attending Seventh-day Adventist boarding schools in Ethiopia. Six of the nine HIV/AIDS-related belief questions were significantly 
related to age levels. Age levels were related to being taught about HIV/AIDS, infected students being allowed in schools, knowing how not to get AIDS, and having talked with a friend, parents, or other adults about AIDS.

The eighth research question sought to identify the relationship between age and knowledge level regarding HIV/AIDS among students attending Seventh-day Adventist boarding schools in Ethiopia. Seven of the 19 HIV/AIDS-related knowledge questions were significantly related to age level. Significant relationships were found between age levels and getting AIDS from (1) holding hands with someone, (2) being bitten by mosquitoes, (3) having blood drawn with a sterile needle, (4) having sex without condoms, (5) being in a class with infected students, and (6) having sex with infected persons. Age was also related to the knowledge of whether pregnant women who have AIDS can infect their unborn babies. Generally, knowledge tended to be more accurate among older students.

The ninth research question sought to determine the relationship between age and sexual behavior in relation to HIV/AIDS among students attending Seventh-day Adventist boarding schools in Ethiopia. Age is significantly related to sexual behavior and practices.

The 10th research question sought to determine the relationship between gender and beliefs towards HIV/AIDS among students attending Seventh-day Adventist boarding schools in Ethiopia. Gender is significantly related is to (1) belief that students should be taught about HIV/AIDS, (2) willingness to be in the same class as someone who has AIDS, and (3) having talked with a friend or parent/adult about HIV/AIDS.

Proportionally, more females have been taught about AIDs and have talked with parents 
or other adults about AIDS, but more males have talked with friends about AIDS and are more willing to be in classes with an HIV/AIDS-infected person.

The 11 th research question sought to identify the relationship between gender and knowledge level in relation to HIV/AIDS among students attending Seventh-day Adventist boarding schools in Ethiopia. There were 19 HIV/AIDS-related knowledge questions. Two of these $(10.52 \%)$ were significantly related to gender. A larger proportion of females incorrectly answered that one can get AIDS by being bitten by mosquitoes and that only homosexuals can get AIDS.

The 12 th research question sought to identify the relationship between gender and sexual behavior in relation to HIV/AIDS among students attending Seventh-day Adventist boarding schools in Ethiopia. Gender is significantly related to sexual behavior and practices. Males tended to be more sexually active and more likely not to use condoms during sexual intercourse.

The 13 th research question sought to identify the relationship between Seventh-day Adventist religious affiliation and belief towards HIV/AIDS among students attending Seventh-day Adventist boarding schools in Ethiopia. There were nine HIV/AIDS-related belief questions. Five of these $(55.55 \%)$ were statistically related to religious affiliation. Compared to non-Seventh-day Adventists, proportionally more Adventist students (1) have been taught about AIDS, (2) agreed that infected students be allowed in school, (3) are willing to be in classes with infected students, and (4) have talked with a friend, parent, or other adults about AIDS.

The 14 th research question sought to identify significant relationships between religious affiliation and 6 of the 19 knowledge questions were found. 
Significantly larger proportions of Seventh-day Adventist students had the incorrect belief that (1) people can get AIDS by donating blood, (2) by having blood drawn with sterile needles, (3) there is a cure for AIDS, and (4) only homosexuals can get AIDS. A smaller proportion of SDA students also believed that using condoms during sexual intercourse can reduce the chances of getting AIDS.

The 15th research question sought to identify the relationship between Seventh-day Adventist religious affiliation and sexual behavior in relation to HIV/AIDS among students attending Seventh-day Adventist boarding schools in Ethiopia. Religious affiliation was not statistically related to sexual behavior and practices. About $30 \%$ of both SDA and non-SDA students were sexually active.

The 16th research question sought to identify the relationship between attendance at Seventh-day Adventist schools and belief towards HIV/AIDS among students attending Seventh-day Adventist boarding schools in Ethiopia. While $90 \%$ or more of the students agree that they should be taught about AIDS in school, this proportion appears to slightly decrease as they have spent more time in SDA schools. Perhaps this can be partly explained by an increasing proportion of students who talked to their parents or other adults in their family (50\%-60\%) about AIDS.

The 17th research question sought to identify the relationship between attendance at Seventh-day Adventist schools and knowledge level in relation to HIV/AIDS among students attending Seventh-day Adventist boarding schools in Ethiopia. Twelve of 19 knowledge-related questions were significantly related to length of years of attendance in SDA schools. In general, knowledge tended to be more accurate as students spent more time in SDA schools. 
The 18 th research question sought to identify the relationship between attendance at Seventh-day Adventist schools and sexual behavior in relation to HIV/AIDS among students attending Seventh-day Adventist boarding schools in Ethiopia. No significant relationships were found between length of attendance at SDA schools and sexual behavior and practices.

The 19th research question sought to identify the relationship between the extent to which students talk to their parents or another adult and sexual behavior in relation to HIV/AIDS among students attending Seventh-day Adventist boarding schools in Ethiopia. Sexual behavior is significantly related to whether or not students have talked with their parents or other adults in their family about HIV/AIDS. Those who have talked with their parents or other adults about AIDS tended to be less sexually active. Those who were sexually actively tended to have had their first sexual experience at an older age and were more likely to use condoms during sexual intercourse.

\section{Discussion of the Results}

Almost three-fourths of students indicated that they had been taught about HIV/AIDS in school, and $90.1 \%$ indicated that they know how to keep from getting the HIV virus. However, one-third (31.6\%) reported that they did not know where to get good information about HIV/AIDS, and $28.8 \%$ did not know where to get tested. Although there is support that HIV/AIDS is taught in school, it is clear that the topic is not discussed thoroughly in the schools. This is further supported when only $37.4 \%$ indicated that a student with HIV/AIDS infection should be allowed to go to their school. It would seem that if material was disseminated thoroughly and correctly, the fear of 
having a HIV-positive student in class would be less and students would consider the teacher providing the information to be a reliable resource person for HIV/AIDS information.

Although $90.1 \%$ indicated that they know how to keep from getting the virus, $36 \%$ of the students reported that they have been or are sexually active and $17.9 \%$ expressed they sometimes or never use a condom. Almost the same percentage (17.4\%) indicated that a person can get HIV/AIDS by having sexual intercourse without a condom. The apparent discrepancy between belief, knowledge, and sexual behavior can possibly be because some adolescents that I have spoken with in Ethiopia still have the attitude that, "It can't happen to me." Second, in the Seventh-day Adventist setting, the use of condoms is often not discussed and is not considered an option for prevention of sexually transmitted diseases. Therefore, it can be seen that although students indicated they know how to keep from getting the virus, they are still sexually active and many are not using condoms. This supports my opinion that sex education needs to be taught along with a Christian value and moral basis.

Only $56.6 \%$ of students indicated that they have discussed HIV/AIDS with a parent. More than half $(59.5 \%)$ of the students who indicated that they had talked with a parent or adult about HIV/AIDS indicated that they had never had sexual intercourse. More than $60 \%$ of those students who talk to their parents had their sexual debut when they were 17 years or older, compared to only $37 \%$ who indicated they waited until they were 17 to have sexual intercourse. The largest percentage (55.1\%) of sexually active students who talk with a parent indicated that they always use a condom. There is an obvious correlation between sexual behavior and communication with a parent. Students 
are less sexually active, begin sex at a later age, and use condoms more often. The low number of students indicating that they have talked with a parent or adult is possibly because, in Ethiopia, discussions about sex are not culturally acceptable.. Students need to be encouraged and provided with techniques in which they can better learn to communicate with their parents or other responsible adults at an early age.

There was a high rate of incorrect answers to some of the knowledge questions. Seven out of 10 students believe that mosquitoes can spread AIDS, one in two believe that you can get HIV/AIDS from donating blood, and 3 in 10 indicated that a person can get the virus from having blood drawn with a sterile needle. These misconceptions of supposed transmission modes probably result from students not being given the complete picture regarding HIV/AIDS. This study's results on this question differ with a study done on college students in Ethiopia (Petros et al., 1997), where only $8.3 \%$ indicated that HIV is spread by mosquitoes. If students completely understood the concept of the "Window of Hope," it would be easy to see that mosquitoes do not spread HIV or all age groups would be equally affected.

It is reasonable to believe that older students are more sexually active. However, it was surprising to note that the highest percentage (27.8\%) of students indicating that they have had four or more sexual partners in their life and in the last year $(27.8 \%)$ was among the 12- to 13-year-old group. The fact that the percentage is the same (27.8\%) for both questions ("With how many people have you had any kind of sexual intercourse in your life?" and "With how many people have you had any sexual intercourse in the last year?") indicates that students are becoming more sexually active at an earlier age. Of that age group only $16.7 \%$ indicated that they have talked about 
HIV/AIDS with a parent or adult, and only $38.9 \%$ indicated that they have been taught about HIV/AIDS in school, whereas $66.7 \%$ felt they should be taught in school. Ages 12 and 13 are a time of puberty when hormones are coming alive. If adolescents do not have moral and value-driven sex education from their parent/adults or school settings, sexual experimentation can be higher, as was evident.

On the HIV/AIDS-related belief and knowledge questions, there was an obvious positive upward trend in the number of correct responses. Only 3 out of 27 were answered correctly, with the highest percentage by Grade 9 students, 4 out of 27 by Grade 10,5 out of 27 by Grade 11, and 16 out of 27 questions were answered correctly by Grade 12 students. The majority of all students ( $82.0 \%$ of Grade 12 and more than $70 \%$ of all other grades) indicated that they have been taught about HIV/AIDS in school. It can be understood that as students increase in grade level, their beliefs and knowledge will also increase. This information not only comes from school, but the majority of students indicated that they have talked with a friend $(66 . \%$, Grade $9 ; 72.5 \%$, Grade $10 ; 76.9 \%$, Grade 11,80.6\%, Grade 12) about HIV/AIDS. It is therefore imperative that correct information be disseminated to students so that the messages they are passing on will be accurate.

Two possible reasons explain the misconception of getting HIV/AIDS from donating blood and/or having blood drawn with a sterile needle. The first is that students could have misunderstood the question. The second, which I feel is more likely, is that because of the lack of sterile supplies in the country, especially in the rural settings, it is possible that blood could be withdrawn for donation using what are assumed to be sterile supplies, but in fact are not. One erroneous belief that I came across in Ethiopia was that 
some people believe that the blood-donation kits, which are imported, are impregnated with the AIDS virus.

In accordance with the Seventh-day Adventist church's philosophy on sexual abstinence before and outside of marriage, it is surprising to see that there is no significant difference between the sexual behavior of SDA-affiliated students and non-SDA-affiliated students attending SDA boarding schools in Ethiopia. This discrepancy is confusing. Once again, a plausible explanation could be that because premarital and extra-marital sex are not permitted, the topic is simply not discussed at home or in church. Based on the SDA church's philosophy of upholding this biblical belief, the idea that "it can't happen in our church" is also a realistic factor. In that the SDA church holds this biblical truth high, it would be prudent for sexual topics to be discussed in homes and schools as well as from the pulpit in a morally sound and value-oriented manner.

\section{Conclusions and Implications}

This study has identified the following conclusions: (1) there are misconceptions about some of the modes of transmission of the HIV/AIDS virus, (2) there is a low percentage of students who communicate with their parents or other adults about HIV/AIDS, and (3) although students have knowledge about HIV/AIDS, there is still a high percentage of students who are sexually active and are practicing unprotected sex.

Taking into consideration that many students are becoming more sexually active at a younger age and the "Window of Hope" period is from 5-14 years of age, students need to be introduced to the process of value-oriented decision making and healthy choices beginning in the first grade and continuing on throughout the education 
process at levels that are appropriate for each age level. Sex education in itself, encompassing abstinence, how to say "no," self esteem issues, and STDs need to be taught before students are sexually active. Taking into consideration that many students have already had their first sexual experience by the age of 12 , this information must be presented several years before this.

There is a need for HIV/AIDS and sex education in the Seventh-day Adventist boarding schools in Ethiopia to facilitate and sustain responsible behavior based on moral values. Currently there is no structured program for sex education in the SDA school curriculum in Ethiopia. It is recognized that sex education in the school system alone is not the ideal, but in the absence of positive, knowledgeable, and/or any parental support, it is the mode that at the present time can be an effective information-providing medium.

\section{Recommendations}

Based on the findings and conclusions of this study, the following recommendations are made:

1. Replication of this study should be done on high-school students attending non-SDA boarding schools in Ethiopia.

2. Replication of this study should be done using an identical sampling, but looking at different variables such as urban versus rural school setting, urban versus rural home setting, and family structure. 
3. Develop a sex education program that will provide consistent, accurate information in regard to HIV/AIDS for students in all grades based on their appropriate age/grade level.

4. Implement a sex education program that will facilitate and help to sustain responsible behavior based on moral values. Currently there is no structured program for sex education in the SDA school curriculum in Ethiopia. 
APPENDIX 
APPENDIX A

CROSS TABULATION 
Table 22. Percentage of HIV/AIDS-Related Belief by Grade.

\begin{tabular}{|c|c|c|c|c|}
\hline \multirow{2}{*}{ Belief } & \multicolumn{4}{|c|}{ Grade in percent } \\
\hline & 9 & 10 & 11 & 12 \\
\hline \multicolumn{5}{|l|}{ 7. Should students your age be taught about HIV/AIDS infection in school? } \\
\hline 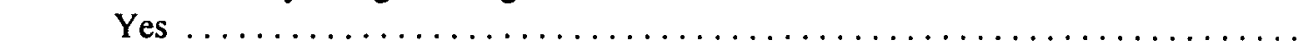 & 94.2 & 93 & 94.6 & 96.7 \\
\hline No $\ldots \ldots \ldots \ldots \ldots$ & 4.0 & 3.8 & 2.7 & 1.4 \\
\hline Not sure & 1.7 & 3.1 & 2.7 & 1.9 \\
\hline \multicolumn{5}{|l|}{ 8. Have you been taught about HIV/AIDS infection in school? } \\
\hline 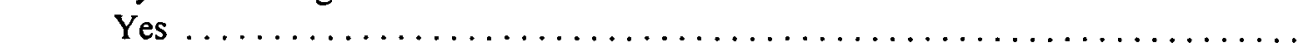 & 70.5 & 70.0 & 71.2 & 82.0 \\
\hline No & 26.9 & 25.1 & 23.7 & 12.3 \\
\hline Not sure . . & 2.6 & 4.9 & 5.0 & 5.7 \\
\hline \multicolumn{5}{|l|}{ 9. Should a student with HIV/AIDS infection be allowed to go to your school? } \\
\hline 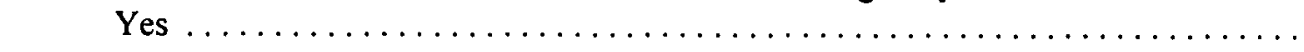 & 37.3 & 35.9 & 38.8 & 37.9 \\
\hline No & 31.5 & 28.6 & 21.1 & 18.5 \\
\hline Not sure $\ldots$ & 31.2 & 35.5 & 40.1 & 43.6 \\
\hline \multicolumn{5}{|l|}{ 10. Would you be willing to be in the same class with a student with HIV/AIDS infection? } \\
\hline Yes $\ldots \ldots \ldots \ldots \ldots \ldots \ldots \ldots \ldots \ldots \ldots \ldots \ldots \ldots \ldots \ldots \ldots \ldots \ldots$ & 53.2 & 51.6 & 62.9 & 64.0 \\
\hline$\ldots \ldots \ldots \ldots \ldots \ldots \ldots \ldots \ldots \ldots \ldots \ldots \ldots \ldots$ & 35.0 & 34.8 & 25.8 & 23.7 \\
\hline ................. & 11.8 & 13.6 & 11. & 12.3 \\
\hline \multirow{2}{*}{\multicolumn{5}{|c|}{ 11. Do you know where to get good information about HIV/AIDS infection? }} \\
\hline & & & & \\
\hline$\ldots \ldots \ldots \ldots \ldots \ldots \ldots \ldots \ldots$ & 60.1 & 53.3 & 55.5 & 60.2 \\
\hline No & 34.7 & 30.3 & 35.1 & 23.7 \\
\hline Not sure $\ldots \ldots \ldots \ldots \ldots$ & 5.2 & 164 & 9.4 & 16.1 \\
\hline
\end{tabular}


Table 22. Continued

\begin{tabular}{|c|c|c|c|c|}
\hline \multirow{2}{*}{ Belief Item } & \multicolumn{4}{|c|}{ Grade in percent } \\
\hline & 9 & 10 & 11 & 12 \\
\hline \multicolumn{5}{|l|}{ 12. Do you know where to get tested to see if you are infected with the AIDS virus? } \\
\hline 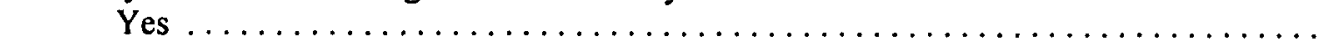 & 65.0 & 58.5 & 59.2 & 63.5 \\
\hline 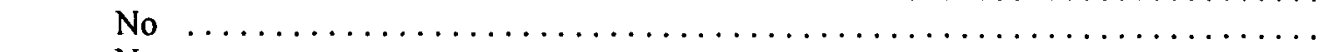 & 28.6 & 30.0 & 30.8 & 25.1 \\
\hline Not sure & 6.4 & 11.5 & 10.0 & 11.4 \\
\hline \multicolumn{5}{|l|}{ 13. Do you know how to keep from getting the HIV/AIDS virus? } \\
\hline 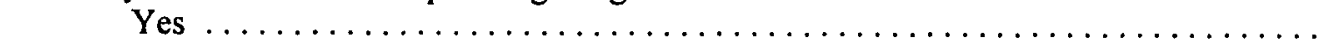 & 89.6 & 90.6 & 89.3 & 91.9 \\
\hline No & 7.8 & 3.8 & 7.0 & 4.7 \\
\hline Not sure & 2.6 & 5.6 & 3.7 & 3.3 \\
\hline \multicolumn{5}{|l|}{ 14. Have you ever talked about HIV/AIDS with a friend? } \\
\hline Yes $\ldots \ldots \ldots \ldots \ldots \ldots \ldots \ldots \ldots \ldots \ldots$ & 66.5 & 72.5 & 76.9 & 80.6 \\
\hline No $\ldots \ldots \ldots \ldots$. & 30.6 & 22.6 & 18.7 & 13.7 \\
\hline Not sure & 2.9 & 4.9 & 4.3 & 5.7 \\
\hline \multicolumn{5}{|l|}{ 15. Have you ever talked about HIV/AIDS with your parents or some other adult in your } \\
\hline family? & 54.9 & 55.1 & 60.2 & 56.9 \\
\hline Yes $\ldots$ & 41.9 & 40.4 & 35.1 & 38.4 \\
\hline No $\ldots .$. & 3.2 & 4.5 & 4.7 & 4.7 \\
\hline Not sure & & & & \\
\hline \multicolumn{5}{|l|}{ 16. Can a person get HIV/AIDS infection from holding hands with someone? } \\
\hline 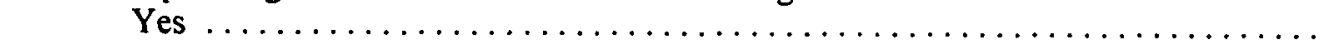 & 8.7 & 2.5 & 8.0 & 8.1 \\
\hline No & 83.2 & 78.0 & 83.6 & 86.7 \\
\hline Not sure & 8.1 & 9.4 & 8.4 & 5.2 \\
\hline
\end{tabular}


Table 23. Percentage of HIV/AIDS-Related Knowledge by Grade.

\begin{tabular}{|c|c|c|c|c|}
\hline \multirow[t]{2}{*}{ Knowledge $\quad$ Item } & \multicolumn{4}{|c|}{ Grade in percent } \\
\hline & 9 & 10 & 11 & 12 \\
\hline 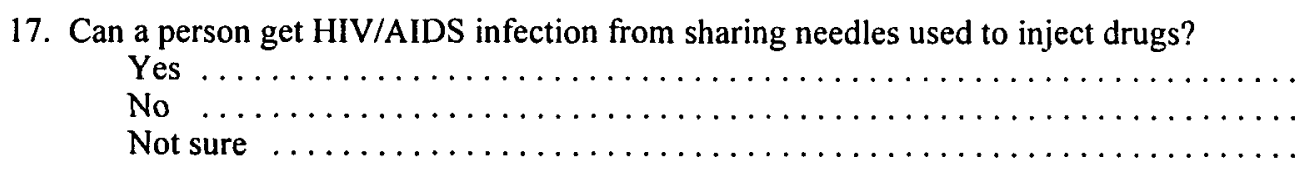 & $\begin{array}{r}86.7 \\
10.1 \\
3.2\end{array}$ & $\begin{array}{r}87.5 \\
7.3 \\
5.2\end{array}$ & $\begin{array}{r}92.6 \\
5.7 \\
1.7\end{array}$ & $\begin{array}{r}91.0 \\
5.2 \\
3.8\end{array}$ \\
\hline 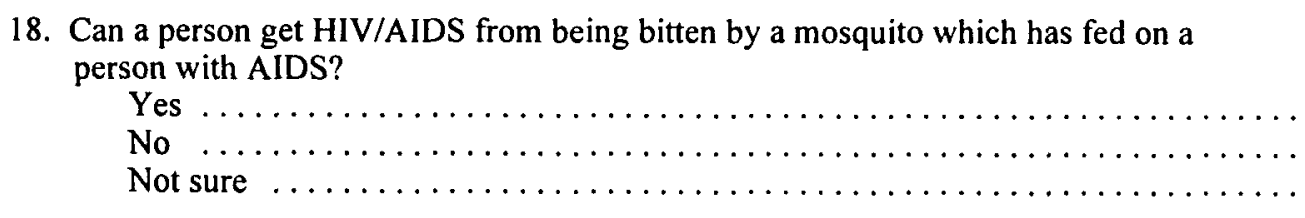 & $\begin{array}{l}52.0 \\
30.3 \\
17.6\end{array}$ & $\begin{array}{l}41.5 \\
37.6 \\
20.9\end{array}$ & $\begin{array}{l}34.8 \\
41.1 \\
24.1\end{array}$ & $\begin{array}{l}33.6 \\
45.0 \\
21.3\end{array}$ \\
\hline 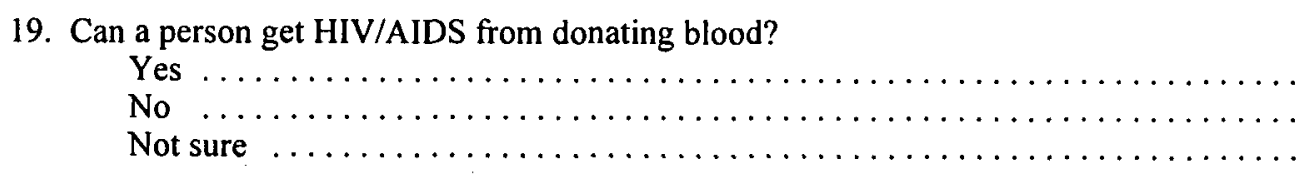 & $\begin{array}{l}52.3 \\
37.0 \\
10.7\end{array}$ & $\begin{array}{l}60.3 \\
23.7 \\
16.0\end{array}$ & $\begin{array}{l}57.5 \\
30.8 \\
11.7\end{array}$ & $\begin{array}{l}54.0 \\
35.5 \\
10.4\end{array}$ \\
\hline 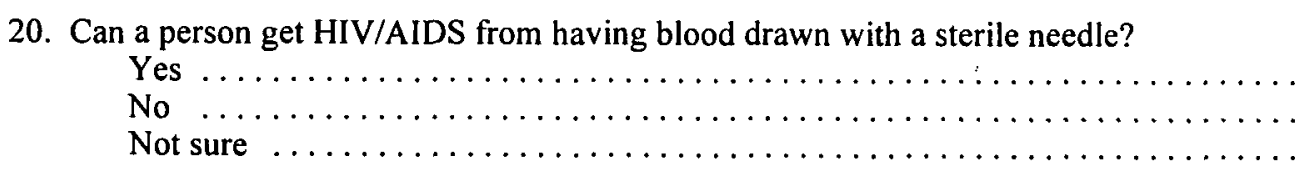 & $\begin{array}{r}30.3 \\
63.6 \\
6.1\end{array}$ & $\begin{array}{r}40.4 \\
51.2 \\
8.4\end{array}$ & $\begin{array}{r}32.4 \\
60.2 \\
7.4\end{array}$ & $\begin{array}{r}24.2 \\
71.6 \\
4.3\end{array}$ \\
\hline 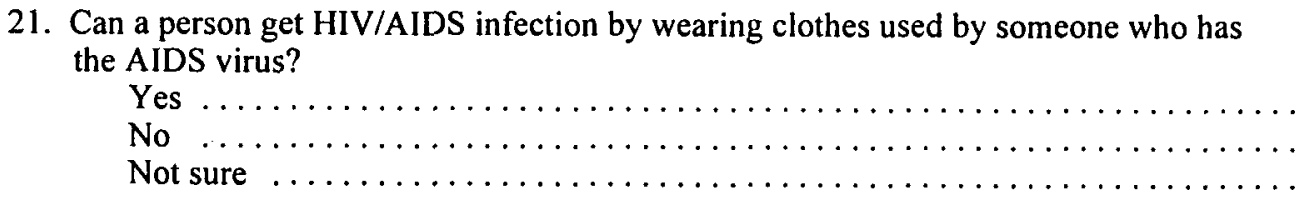 & $\begin{array}{l}15.0 \\
70.8 \\
14.2\end{array}$ & $\begin{array}{l}15.7 \\
69.3 \\
15.0\end{array}$ & $\begin{array}{l}13.4 \\
67.2 \\
19.4\end{array}$ & $\begin{array}{r}8.1 \\
73.0 \\
19.0\end{array}$ \\
\hline
\end{tabular}


Table 23. Continued

\begin{tabular}{|c|c|c|c|c|}
\hline \multirow[t]{2}{*}{ Knowledge } & \multicolumn{4}{|c|}{ Grade in percent } \\
\hline & 9 & 10 & 11 & 12 \\
\hline 22. Can a person get HIV/AIDS infection from having sexual intercourse without using a condom (rubber)? & & & & \\
\hline 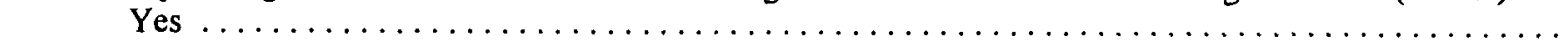 & 62.1 & 72.1 & 71.6 & 70.1 \\
\hline No $\ldots$... & 24.6 & 15.0 & 14.0 & 13.7 \\
\hline Not sure & 13.3 & 12.9 & 14.4 & 16.1 \\
\hline \multicolumn{5}{|l|}{ 23. Can a person get HIV/AIDS infection from being in the same class with a student who has AIDS/HIV? } \\
\hline 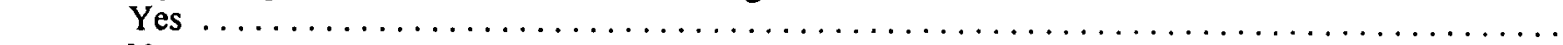 & 12.1 & 11.1 & 8.7 & 5.2 \\
\hline No $\ldots$. & 79.2 & 76.3 & 79.3 & 87.2 \\
\hline Not sure & 8.7 & 12.5 & 12.0 & 7.6 \\
\hline \multicolumn{5}{|l|}{ 24. Can you tell if people are infected with the AIDS virus (HIV) just by looking at them? } \\
\hline 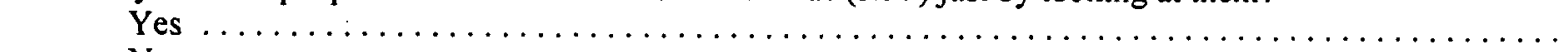 & 22.0 & 14.6 & 12.7 & 9.5 \\
\hline No & 65.9 & 72.5 & 68.6 & 71.1 \\
\hline Not sure & 12.1 & 12.9 & 18.7 & 19.4 \\
\hline \multicolumn{5}{|l|}{ 25. Can a person who has the AIDS virus (HIV) infect someone else during sexual intercourse? } \\
\hline Yes & 83.5 & 88.2 & 88.6 & 88.2 \\
\hline No & 10.7 & 8.0 & 8.7 & 7.6 \\
\hline Not sure & 5.5 & 3.8 & 2.7 & 4.3 \\
\hline \multicolumn{5}{|l|}{ 26. Can a pregnant woman who has the AIDS virus (HIV) infect her unborn baby with the virus? } \\
\hline$\ldots \ldots$ & 84.1 & 91.3 & 87.6 & 91.9 \\
\hline No $\ldots$ & 10.1 & 4.9 & 6.4 & 2.8 \\
\hline Not sure . & 5.8 & 3.8 & 6.0 & 5.2 \\
\hline
\end{tabular}


Table 23. Continued

\begin{tabular}{|c|c|c|c|c|}
\hline \multirow[t]{2}{*}{ Knowledge $\quad$ Item } & \multicolumn{4}{|c|}{ Grade in percent } \\
\hline & 9 & 10 & 11 & 12 \\
\hline \multicolumn{5}{|l|}{ 27. Is there a cure for HIV/AIDS infection? } \\
\hline Yes $\ldots \ldots \ldots \ldots \ldots \ldots \ldots$ & 22.3 & 24.4 & 23.1 & 19.4 \\
\hline No & 66.5 & 62.0 & 65.9 & 69.2 \\
\hline Not sure . & 11.3 & 13.6 & 11.0 & 11.4 \\
\hline \multicolumn{5}{|l|}{ 28. Is it true that only homosexual men can get the HIV/AIDS infection? } \\
\hline 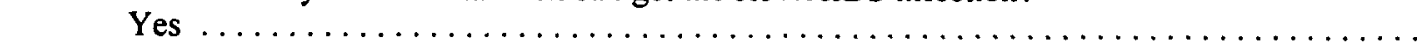 & 31.2 & 27.2 & 21.1 & 22.3 \\
\hline No & 39.9 & 39.0 & 45.2 & 51.2 \\
\hline Not sure & 28.9 & 33.8 & 33.8 & 26.5 \\
\hline \multicolumn{5}{|l|}{$\begin{array}{l}\text { 29. Can people reduce their chances of becoming infected with the HIV/AIDS virus by not having } \\
\text { any kind of sexual intercourse? }\end{array}$} \\
\hline Yes & 50.6 & 52.3 & 46.5 & 52.6 \\
\hline No & 37.3 & 32.8 & 34.1 & 34.1 \\
\hline Not sure ... & 12.1 & 15.0 & 19.4 & 13.3 \\
\hline \multicolumn{5}{|l|}{$\begin{array}{l}\text { 30. Can people reduce their chances of becoming infected with the AIDS virus (HIV) by using } \\
\text { condoms } \\
\text { (rubbers) during sexual intercourse? }\end{array}$} \\
\hline 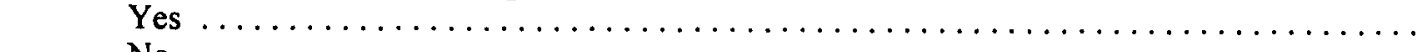 & 72.3 & 70.4 & 64.5 & 70.1 \\
\hline No $\ldots$. & 17.6 & 16.7 & 22.1 & 15.6 \\
\hline Not sure & 10.1 & 12.9 & 13.4 & 14.2 \\
\hline \multicolumn{5}{|l|}{$\begin{array}{l}\text { 31. Can people reduce their chances of becoming infected with the AIDS virus (HIV) by } \\
\text { not having any kind of sexual intercourse with a person who has injected (shot up) drugs? }\end{array}$} \\
\hline 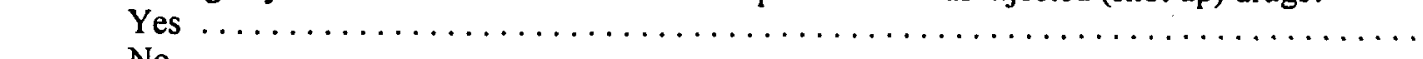 & 32.4 & 24.4 & 32.4 & 20.4 \\
\hline No $\ldots \ldots \ldots$ & 50.9 & 55.4 & 44.5 & 57.3 \\
\hline Not sure $\ldots \ldots \ldots \ldots \ldots$ & 16.8 & 20.2 & 23.1 & 22.3 \\
\hline
\end{tabular}


Table 23. Continued

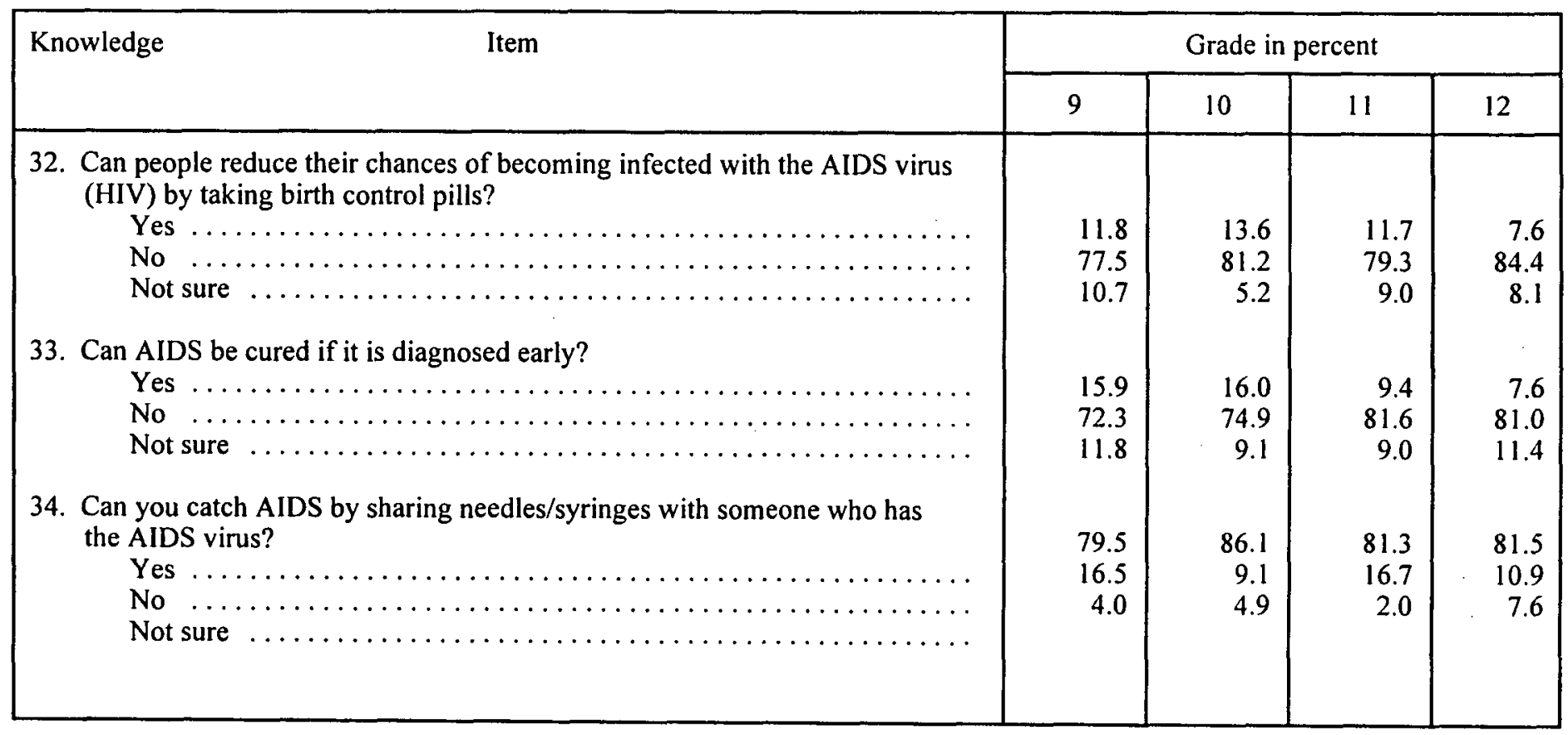


Table 24. Percentage of HIV/AIDS-Related Sexual Behaviors by Grade.

\begin{tabular}{|c|c|c|c|c|}
\hline \multirow[t]{2}{*}{ Behavior Item } & \multicolumn{4}{|c|}{ Grade by percent } \\
\hline & 9 & 10 & 11 & 12 \\
\hline 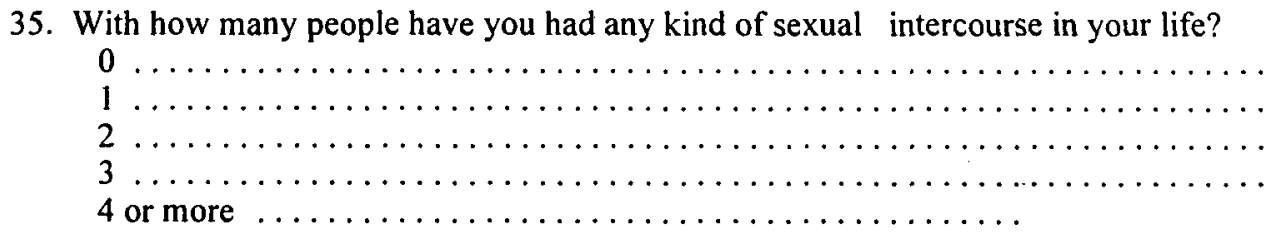 & $\begin{array}{r}77.2 \\
4.6 \\
4.0 \\
2.9 \\
11.3\end{array}$ & $\begin{array}{r}78.0 \\
4.2 \\
5.6 \\
1.7 \\
10.5\end{array}$ & $\begin{array}{r}68.9 \\
8.7 \\
6.0 \\
3.7 \\
12.7\end{array}$ & $\begin{array}{r}69.7 \\
7.6 \\
5.7 \\
1.4 \\
15.6\end{array}$ \\
\hline 36. With how many people have you had any kind of sexual intercourse in the last year? & & & & \\
\hline 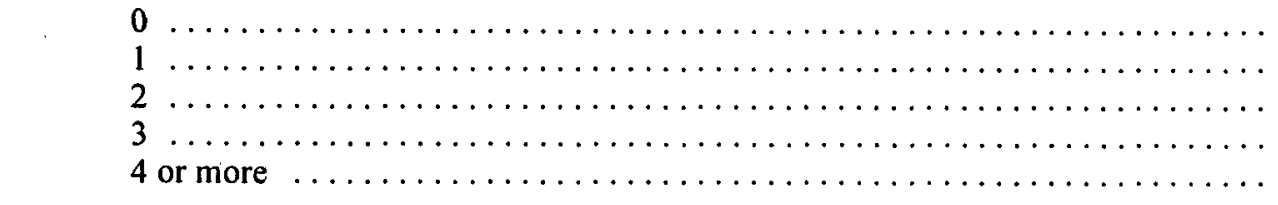 & $\begin{array}{r}81.8 \\
4.6 \\
4.0 \\
3.5 \\
6.1\end{array}$ & $\begin{array}{r}84.0 \\
3.8 \\
3.1 \\
1.0 \\
8.0\end{array}$ & $\begin{array}{r}76.6 \\
10.4 \\
4.0 \\
1.3 \\
7.7\end{array}$ & $\begin{array}{r}75.8 \\
9.5 \\
3.3 \\
3.8 \\
7.6\end{array}$ \\
\hline 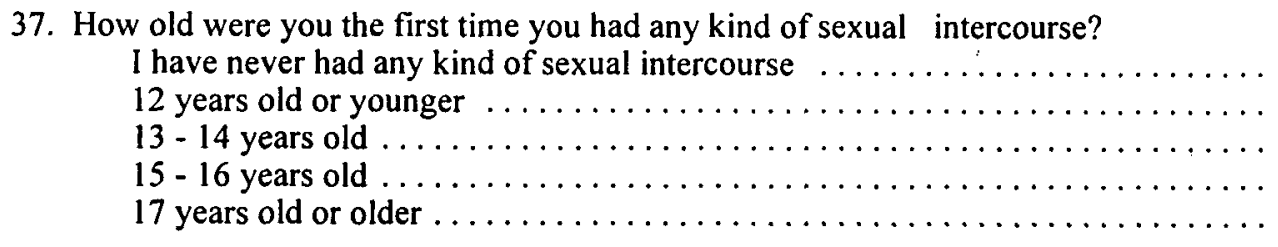 & $\begin{array}{r}76.9 \\
8.7 \\
5.5 \\
6.1 \\
2.9\end{array}$ & $\begin{array}{r}79.4 \\
4.9 \\
3.5 \\
10.1 \\
2.1\end{array}$ & $\begin{array}{r}69.9 \\
6.7 \\
6.4 \\
10.4 \\
6.7\end{array}$ & $\begin{array}{r}69.7 \\
7.6 \\
1.9 \\
12.3 \\
8.5\end{array}$ \\
\hline 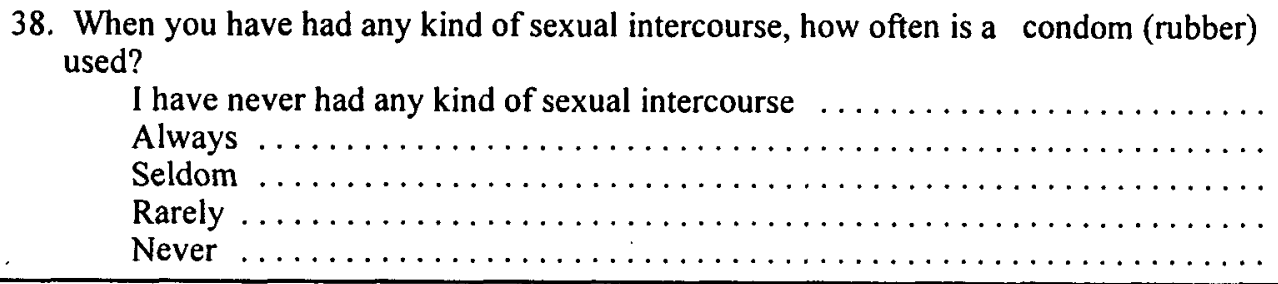 & $\begin{array}{r}76.6 \\
5.5 \\
3.8 \\
4.0 \\
10.1\end{array}$ & $\begin{array}{r}79.4 \\
4.9 \\
3.1 \\
3.8 \\
8.7\end{array}$ & $\begin{array}{r}70.2 \\
11.0 \\
7.7 \\
4.0 \\
7.0\end{array}$ & $\begin{array}{r}69.7 \\
10.9 \\
2.8 \\
4.7 \\
11.8\end{array}$ \\
\hline
\end{tabular}


Table 25. Percentage of HIV/AIDS-Related Belief by Age.

\begin{tabular}{|c|c|c|c|c|c|}
\hline \multirow{2}{*}{ Belief } & \multicolumn{5}{|c|}{ Age in percent } \\
\hline & $12-13$ & $14-15$ & $16-17$ & $18-19$ & $20-23$ \\
\hline \multicolumn{6}{|l|}{$\begin{array}{l}\text { 7. Should students your age be taught about HIV/AIDS infection } \\
\text { in school? }\end{array}$} \\
\hline Yes & 66.7 & 95.2 & 94.7 & 95.0 & 96.9 \\
\hline & 33.3 & 2.8 & 2.5 & 2.8 & 1.6 \\
\hline Not sure & & 2.0 & 2.9 & 2.2 & 1.6 \\
\hline \multicolumn{6}{|l|}{ 8. Have you been taught about HIV/AIDS infection in school? } \\
\hline 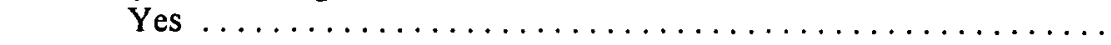 & 38.9 & 65.7 & 70.8 & 82.0 & 79.7 \\
\hline No $\ldots .$. . & 38.9 & 30.6 & 24.9 & 13.4 & 20.3 \\
\hline Not sure & 22.2 & 3.6 & 4.3 & 4.7 & \\
\hline \multicolumn{6}{|l|}{$\begin{array}{l}\text { 9. Should a student with HIV/AIDS infection be allowed to go } \\
\text { to your school? }\end{array}$} \\
\hline Yes $\ldots \ldots \ldots \ldots \ldots \ldots \ldots \ldots \ldots \ldots \ldots \ldots \ldots$ & 11.1 & 35.1 & 37.4 & 39.8 & 42.2 \\
\hline No... & 44.4 & 29.4 & 24.9 & 21.1 & 34.4 \\
\hline Not sure .. & 44.4 & 35.5 & 37.7 & 39.1 & 23.4 \\
\hline \multicolumn{6}{|l|}{$\begin{array}{l}\text { 10. Would you be willing to be in the same class with a student } \\
\text { with HIV/AIDS? }\end{array}$} \\
\hline Yes & 50.0 & 54.4 & 59.3 & 56.8 & 59.4 \\
\hline No $\ldots .$. . & 27.8 & 34.7 & 28.2 & 30.1 & 34.4 \\
\hline Not sure & 22.2 & 10.9 & 12.6 & 13.0 & 6.3 \\
\hline \multicolumn{6}{|l|}{ 11. Do you know where to get good information about HIV/AIDS infection? } \\
\hline Yes. & 66.7 & 58.9 & 52.3 & 61.8 & 62.5 \\
\hline No $\ldots$. & 27.8 & 31.0 & 35.2 & 27.6 & 29.7 \\
\hline Not sure $\ldots \ldots \ldots \ldots$ & 5.6 & 10.1 & 12.6 & 10.6 & 7.8 \\
\hline
\end{tabular}


Table 25. Continued

\begin{tabular}{|c|c|c|c|c|c|}
\hline \multirow{2}{*}{ Belief Item } & \multicolumn{5}{|c|}{ Age in percent } \\
\hline & $12-13$ & $14-15$ & $16-17$ & $18-19$ & $20-23$ \\
\hline \multicolumn{6}{|l|}{ 12. Do you know where to get tested to see if you are infected with the AIDS virus? } \\
\hline 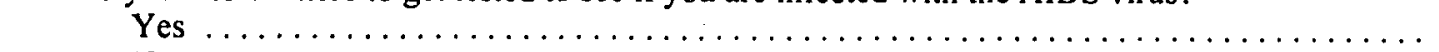 & 66.7 & 58.5 & 60.7 & 64.0 & 67.2 \\
\hline 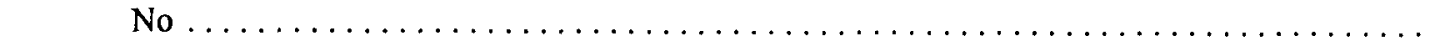 & 22.2 & 32.7 & 30.2 & 25.2 & 25.0 \\
\hline Not sure $\ldots$ & 11.1 & 8.9 & 9.1 & 10.9 & 7.8 \\
\hline \multicolumn{6}{|l|}{ 13. Do you know how to keep from getting the HIV/AIDS virus? } \\
\hline 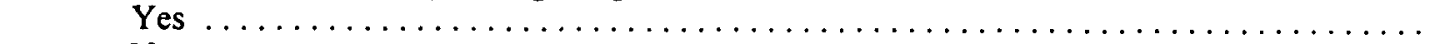 & 83.3 & 89.5 & 89.5 & 92.2 & 90.6 \\
\hline No .... & & 8.1 & 5.1 & 5.3 & 9.4 \\
\hline Not sure $\ldots \ldots \ldots$ & 16.7 & 2.4 & 5.3 & 2.5 & \\
\hline \multicolumn{6}{|l|}{ 14. Have you ever talked about HIV/AIDS with a friend? } \\
\hline Yes $\ldots \ldots \ldots \ldots \ldots \ldots \ldots \ldots \ldots \ldots \ldots$ & 50.0 & 64.9 & 71.6 & 82.0 & 81.3 \\
\hline No ..... & & 32.3 & 23.5 & 13.0 & 17.2 \\
\hline Not sure & 50.0 & 2.8 & 4.9 & 5.0 & 1.6 \\
\hline \multicolumn{6}{|l|}{ 15. Have you ever talked about HIV/AIDS with your parents or some other adult in your family? } \\
\hline Yes & 16.7 & 53.2 & 54.9 & 62.4 & 65.6 \\
\hline 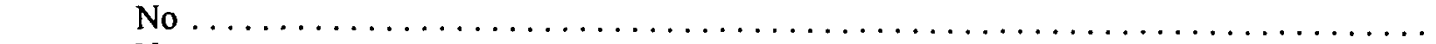 & 66.7 & 43.5 & 41.6 & 32.3 & 32.8 \\
\hline Not sure & 16.7 & 3.2 & 3.5 & 5.3 & 1.6 \\
\hline
\end{tabular}


Table 26. Percentage of HIV/AIDS Related Knowledge by Age.

\begin{tabular}{|c|c|c|c|c|c|}
\hline \multirow[t]{2}{*}{ Knowledge $\quad$ Item } & \multicolumn{5}{|c|}{ Age in percent } \\
\hline & $12-13$ & $14-15$ & $16-17$ & $18-19$ & $20-23$ \\
\hline \multicolumn{6}{|l|}{ 16. Can a person get HIV/AIDS infection from holding hands with someone? } \\
\hline 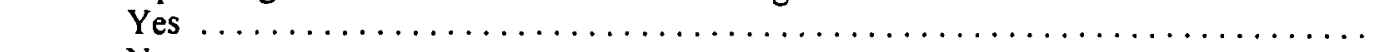 & 38.9 & 8.9 & 9.1 & 9.3 & 4.7 \\
\hline No .... & 55.6 & 84.3 & 83.1 & 82.0 & 87.5 \\
\hline Not sure & 5.6 & 6.9 & 7.8 & 8.7 & 7.8 \\
\hline \multicolumn{6}{|l|}{ 17. Can a person get HIV/AIDS infection from sharing needles used to inject drugs? } \\
\hline$\ldots \ldots \ldots \ldots \ldots \ldots \ldots \ldots \ldots$ & 83.3 & 89.9 & 89.5 & 88.2 & 92.2 \\
\hline No... . & 11.1 & 9.3 & 7.0 & 6.2 & 6.3 \\
\hline Not sure & 5.6 & .8 & 3.5 & 5.6 & 1.6 \\
\hline \multicolumn{6}{|l|}{$\begin{array}{l}\text { 18. Can a person get HIV/AIDS from being bitten by a mosquito which has fed on a person } \\
\text { with AIDS? }\end{array}$} \\
\hline Yes. & 55.6 & 52.0 & 42.2 & 33.2 & 34.4 \\
\hline No $\ldots \ldots$ & 22.2 & 30.2 & 36.4 & 43.5 & 53.1 \\
\hline Not sure & 22.2 & 17.7 & 21.4 & 23.3 & 12.5 \\
\hline \multicolumn{6}{|l|}{ 19. Can a person get HIV/AIDS from donating blood? } \\
\hline-5 & 44.4 & 54.8 & 53.7 & 59.0 & 68.8 \\
\hline No $\ldots . .$. & 27.8 & 33.9 & 33.3 & 30.7 & 17.2 \\
\hline Not sure & 27.8 & 11.3 & 13.0 & 10.2 & 14.1 \\
\hline \multicolumn{6}{|l|}{ 20. Can a person get HIV/AIDS from having blood drawn with a sterile needle? } \\
\hline 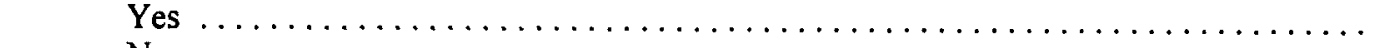 & 22.2 & 27.4 & 33.5 & 31.7 & 46.9 \\
\hline No $\ldots .$. & 77.8 & 63.7 & 59.1 & 63.7 & 48.4 \\
\hline Not sure & & 8.9 & 7.4 & 4.7 & 4.7 \\
\hline
\end{tabular}


Table 26. Continued

\begin{tabular}{|c|c|c|c|c|c|}
\hline \multirow[t]{2}{*}{ Knowledge $\quad$ Item } & \multicolumn{5}{|c|}{ Age in percent } \\
\hline & $12-13$ & $14-15$ & $16-17$ & $18-19$ & $20-23$ \\
\hline \multicolumn{6}{|l|}{$\begin{array}{l}\text { 21. Can a person get HIV/AIDS infection by wearing clothes used by someone who has the AIDS } \\
\text { virus? }\end{array}$} \\
\hline Yes & 33.3 & 14.1 & 14.8 & 10.6 & 10.9 \\
\hline & 44.4 & 72.2 & 67.5 & 73.0 & 71.9 \\
\hline Not sure & 22.2 & 13.7 & 17.7 & 16.5 & 17.2 \\
\hline \multicolumn{6}{|l|}{$\begin{array}{l}\text { 22. Can a person get HIV/AIDS infection from having sexual intercourse without using a condom } \\
\text { (rubber)? }\end{array}$} \\
\hline 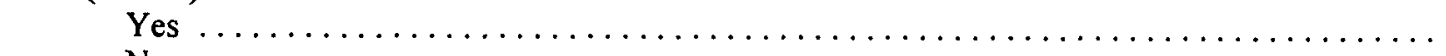 & 61.1 & 65.7 & 66.7 & 71.1 & 81.3 \\
\hline No ..... & 38.9 & 21.0 & 16.7 & 15.8 & 12.5 \\
\hline Not sure . . & & 13.3 & 16.7 & 13.0 & 6.3 \\
\hline \multicolumn{6}{|l|}{$\begin{array}{l}\text { 23. Can a person get HIV/AIDS infection from being in the same class with a student who } \\
\text { has AIDS/HIV? }\end{array}$} \\
\hline Yes & 11.1 & 11.3 & 10.3 & 7.8 & 7.8 \\
\hline No . & 83.3 & 79.8 & 78.2 & 82.9 & 78.1 \\
\hline Not sure $\ldots$ & 5.6 & 8.9 & 11.5 & 9.3 & 14.1 \\
\hline \multicolumn{6}{|l|}{ 24. Can you tell if people are infected with the AIDS virus (HIV) just by looking at them? } \\
\hline${ }^{\prime}$ & 55.6 & 17.7 & 16.5 & 10.2 & 14.1 \\
\hline 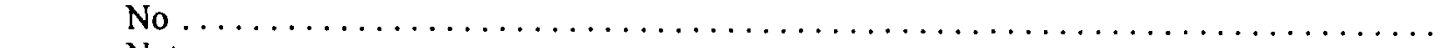 & 22.2 & 67.3 & 69.1 & 72.4 & 73.4 \\
\hline Not sure & 22.2 & 14.9 & 14.4 & 17.4 & 12.5 \\
\hline \multicolumn{6}{|l|}{ 25. Can a person who has the AIDS virus (HIV) infect someone during sexual intercourse? } \\
\hline Yes & 94.4 & 85.1 & 88.3 & 87.0 & 79.7 \\
\hline No & & 9.7 & 7.8 & 8.7 & 18.8 \\
\hline Not sure $\ldots \ldots \ldots \ldots \ldots \ldots$ & 5.6 & 4.8 & 3.9 & 4.3 & 1.6 \\
\hline
\end{tabular}


Table 26. Continued

\begin{tabular}{|c|c|c|c|c|c|}
\hline \multirow[t]{2}{*}{ Knowledge Item } & \multicolumn{5}{|c|}{ Age in percent } \\
\hline & $12-13$ & $14-15$ & $16-17$ & $18-19$ & $20-23$ \\
\hline 26. Can a pregnant woman who has the AIDS virus (HIV) infect her unborn baby with the virus? & & & & & \\
\hline Yes $\ldots \ldots \ldots \ldots \ldots \ldots \ldots$. & 61.1 & 85.5 & 88.9 & 91.3 & 85.9 \\
\hline No & 33.3 & 6.9 & 6.0 & 5.3 & 7.8 \\
\hline Not sure & 5.6 & 7.7 & 5.2 & 3.4 & 6.3 \\
\hline \multicolumn{6}{|l|}{ 27. Is there a cure for HIV/AIDS infection? } \\
\hline Yes $\ldots \ldots \ldots \ldots \ldots \ldots \ldots$ & 16.7 & 21.8 & 23.0 & 23.3 & 17.2 \\
\hline No & 44.4 & 66.1 & 65.6 & 65.8 & 70.3 \\
\hline Not sure & 38.9 & 12.1 & 11.3 & 10.9 & 12.5 \\
\hline \multicolumn{6}{|l|}{ 28. Is it true that only homosexual men can get the HIV/AIDS infection? } \\
\hline 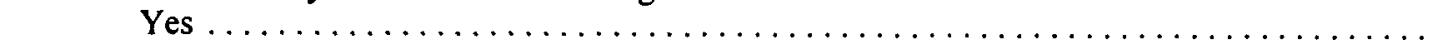 & 44.4 & 25.8 & 24.3 & 25.8 & 34.4 \\
\hline No & 22.2 & 40.7 & 42.0 & 47.8 & 43.8 \\
\hline Not sure & 33.3 & 33.5 & 33.7 & 26.4 & 21.9 \\
\hline \multicolumn{6}{|l|}{$\begin{array}{l}\text { 29. Can people reduce their chances of becoming infected with the HIV/AIDS virus by not } \\
\text { having any kind of sexual intercourse? }\end{array}$} \\
\hline Yes & 44.4 & 52.8 & 49.8 & 49.7 & 48.4 \\
\hline No & 44.4 & 33.9 & 34.4 & 34.2 & 40.6 \\
\hline Not sure & 11.1 & 13.3 & 15.8 & 16.1 & 10.9 \\
\hline \multicolumn{6}{|l|}{$\begin{array}{l}\text { 30. Can people reduce their chances of becoming infected with the AIDS virus (HIV) by using } \\
\text { condoms (rubbers) during sexual intercourse? }\end{array}$} \\
\hline Yes & 61.1 & 71.0 & 71.4 & 67.4 & 64.1 \\
\hline No & 27.8 & 19.8 & 16.0 & 18.9 & 20.3 \\
\hline Not sure & 11.1 & 9.3 & 12.6 & 13.7 & 15.6 \\
\hline
\end{tabular}


Table 26. Continued

\begin{tabular}{|c|c|c|c|c|c|}
\hline \multirow[t]{2}{*}{ Knowledge $\quad$ Item } & \multicolumn{5}{|c|}{ Age in percent } \\
\hline & $12-13$ & $14-15$ & $16-17$ & $18-19$ & $20-23$ \\
\hline 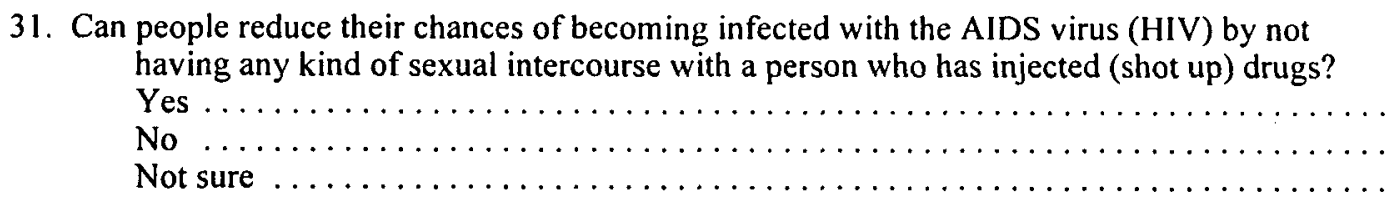 & $\begin{array}{l}16.7 \\
72.2 \\
11.1\end{array}$ & $\begin{array}{l}30.6 \\
51.2 \\
18.1\end{array}$ & $\begin{array}{l}29.8 \\
50.2 \\
20.0\end{array}$ & $\begin{array}{l}24.8 \\
52.5 \\
22.7\end{array}$ & $\begin{array}{l}26.6 \\
51.6 \\
21.9\end{array}$ \\
\hline 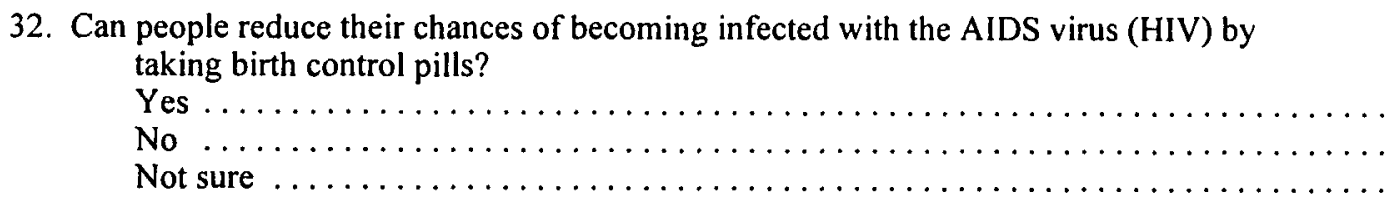 & $\begin{array}{l}22.2 \\
66.7 \\
11.1\end{array}$ & $\begin{array}{r}14.1 \\
77.4 \\
8.5\end{array}$ & $\begin{array}{r}9.7 \\
82.1 \\
8.2\end{array}$ & $\begin{array}{r}11.8 \\
80.1 \\
8.1\end{array}$ & $\begin{array}{r}9.4 \\
79.7 \\
10.9\end{array}$ \\
\hline 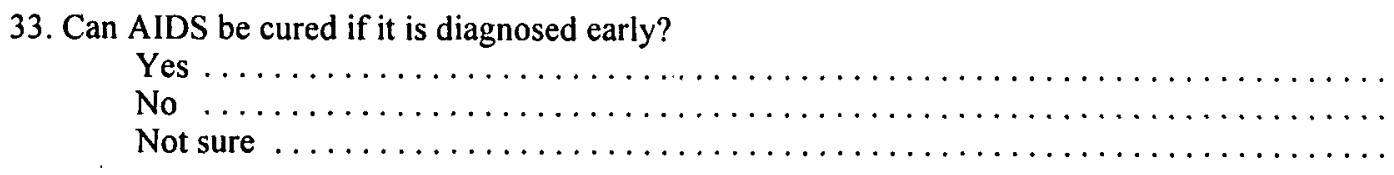 & $\begin{array}{r}27.8 \\
66.7 \\
5.6\end{array}$ & $\begin{array}{l}12.9 \\
77.0 \\
10.1\end{array}$ & $\begin{array}{l}12.3 \\
77.0 \\
10.7\end{array}$ & $\begin{array}{r}12.7 \\
77.3 \\
9.9\end{array}$ & $\begin{array}{r}9.4 \\
78.1 \\
9.9\end{array}$ \\
\hline 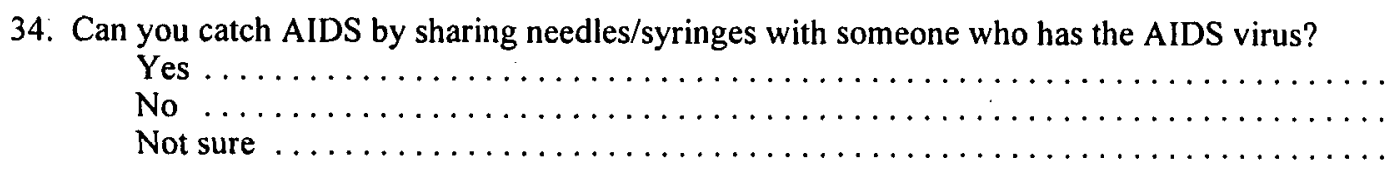 & $\begin{array}{r}66.7 \\
27.8 \\
5.6\end{array}$ & $\begin{array}{r}80.6 \\
14.5 \\
4.8\end{array}$ & $\begin{array}{r}84.0 \\
12.3 \\
3.7\end{array}$ & $\begin{array}{r}80.7 \\
14.6 \\
4.7\end{array}$ & $\begin{array}{r}81.3 \\
12.5 \\
6.3\end{array}$ \\
\hline
\end{tabular}


Table 27. Percentage of HIV/AIDS Related Sexual Behavior by Age

\begin{tabular}{|c|c|c|c|c|c|}
\hline \multirow{2}{*}{ Behavior $\quad$ Item } & \multicolumn{5}{|c|}{ Age by percent } \\
\hline & $12-13$ & $14-15$ & $16-17$ & $18-19$ & $20-23$ \\
\hline 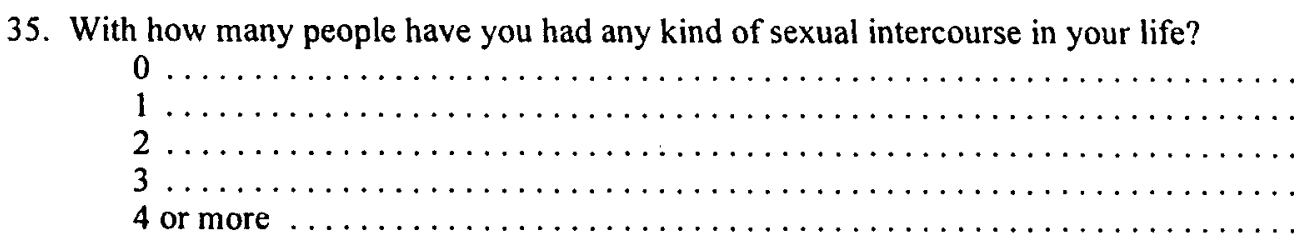 & $\begin{array}{r}61.1 \\
5.6 \\
5.6 \\
27.8\end{array}$ & $\begin{array}{r}85.1 \\
2.8 \\
1.6 \\
.4 \\
10.1\end{array}$ & $\begin{array}{r}73.7 \\
6.2 \\
6.4 \\
3.3 \\
10.5\end{array}$ & $\begin{array}{r}69.6 \\
7.1 \\
6.2 \\
2.2 \\
14.9\end{array}$ & $\begin{array}{r}54.7 \\
15.6 \\
6.3 \\
6.3 \\
17.2\end{array}$ \\
\hline 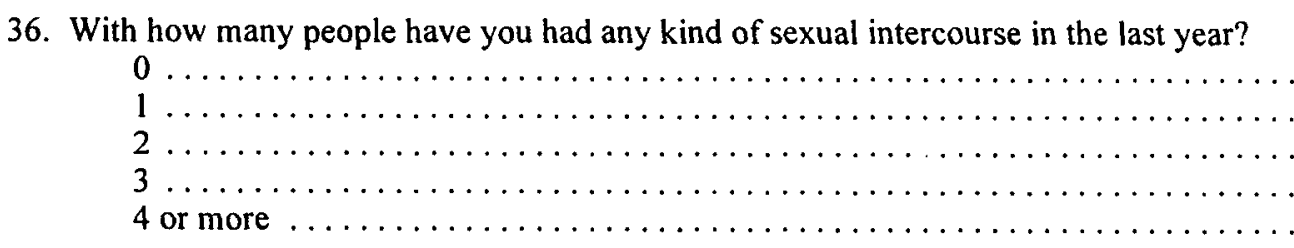 & $\begin{array}{l}61.1 \\
11.1 \\
27.8\end{array}$ & $\begin{array}{r}86.7 \\
2.4 \\
2.8 \\
2.8 \\
5.2\end{array}$ & $\begin{array}{r}80.5 \\
6.8 \\
3.3 \\
1.9 \\
7.6\end{array}$ & $\begin{array}{r}75.5 \\
9.6 \\
4.0 \\
3.1 \\
7.8\end{array}$ & $\begin{array}{r}75.0 \\
12.5 \\
6.3 \\
1.6 \\
4.7\end{array}$ \\
\hline 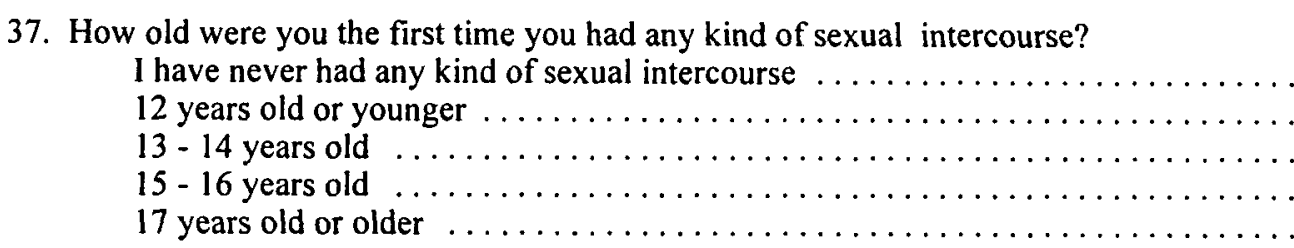 & $\begin{array}{r}55.6 \\
22.2 \\
11.1 \\
5.6 \\
5.6\end{array}$ & $\begin{array}{r}85.5 \\
7.3 \\
4.4 \\
2.4 \\
.4\end{array}$ & $\begin{array}{r}73.9 \\
6.6 \\
4.9 \\
10.9 \\
3.7\end{array}$ & $\begin{array}{r}70.8 \\
5.9 \\
3.4 \\
12.1 \\
7.8\end{array}$ & $\begin{array}{r}56.3 \\
10.9 \\
6.3 \\
12.5 \\
14.1\end{array}$ \\
\hline 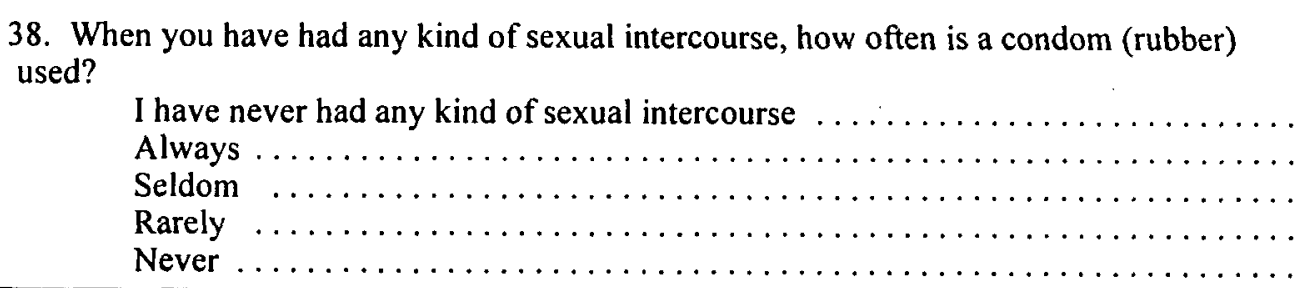 & $\begin{array}{r}61.1 \\
11.1 \\
5.6 \\
5.6 \\
16.7\end{array}$ & $\begin{array}{r}85.1 \\
3.2 \\
1.6 \\
2.4 \\
7.7\end{array}$ & $\begin{array}{r}73.7 \\
8.6 \\
4.9 \\
3.9 \\
8.8\end{array}$ & $\begin{array}{r}70.8 \\
9.9 \\
5.0 \\
5.0 \\
9.3\end{array}$ & $\begin{array}{r}57.8 \\
7.8 \\
9.4 \\
7.8 \\
17.2\end{array}$ \\
\hline
\end{tabular}


Table 28. Percentage of HIV/AIDS Related Belief by Gender

\begin{tabular}{|c|c|c|}
\hline \multirow{2}{*}{ Belief Item } & \multicolumn{2}{|c|}{ Gender in percent } \\
\hline & Females & Males \\
\hline 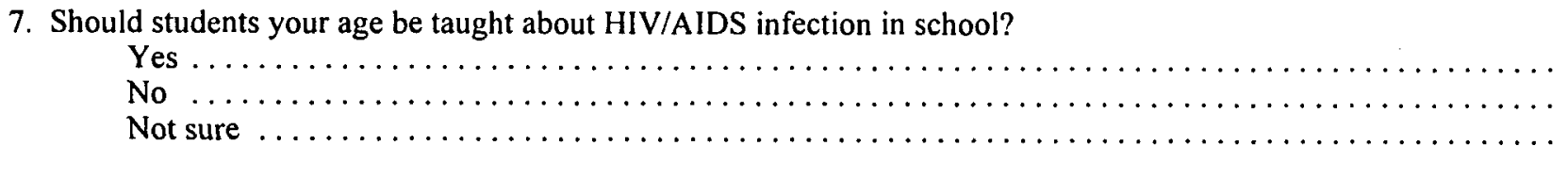 & $\begin{array}{r}95.8 \\
1.5 \\
2.6\end{array}$ & $\begin{array}{r}93.8 \\
4.0 \\
2.2\end{array}$ \\
\hline 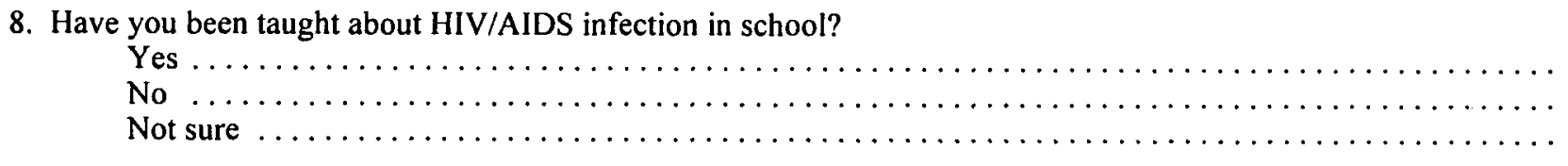 & $\begin{array}{r}78.2 \\
18.1 \\
3.7\end{array}$ & $\begin{array}{r}69.7 \\
25.7 \\
4.6\end{array}$ \\
\hline 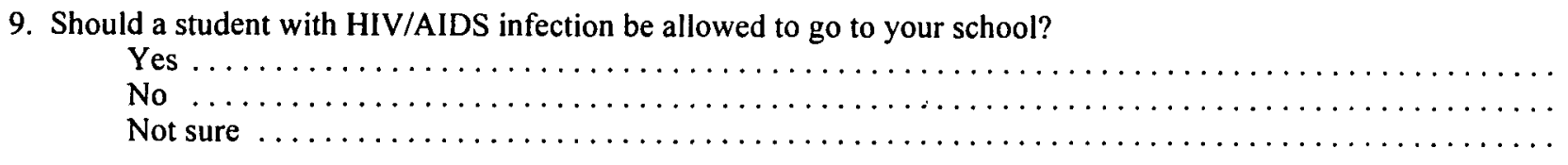 & $\begin{array}{l}35.2 \\
29.1 \\
35.7\end{array}$ & $\begin{array}{l}39.1 \\
23.1 \\
37.9\end{array}$ \\
\hline 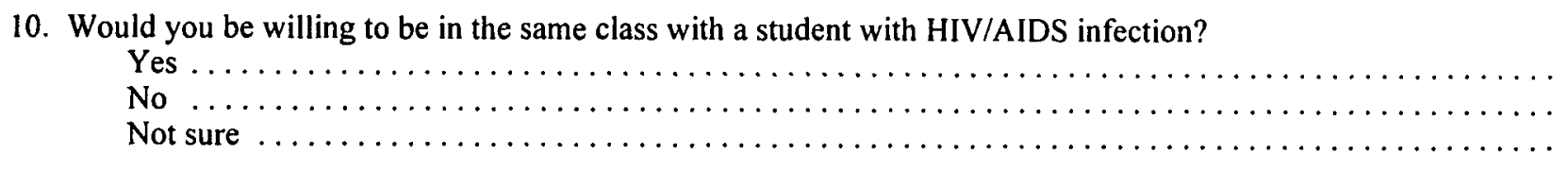 & $\begin{array}{l}51.5 \\
35.2 \\
13.2\end{array}$ & $\begin{array}{l}61.2 \\
27.2 \\
11.5\end{array}$ \\
\hline 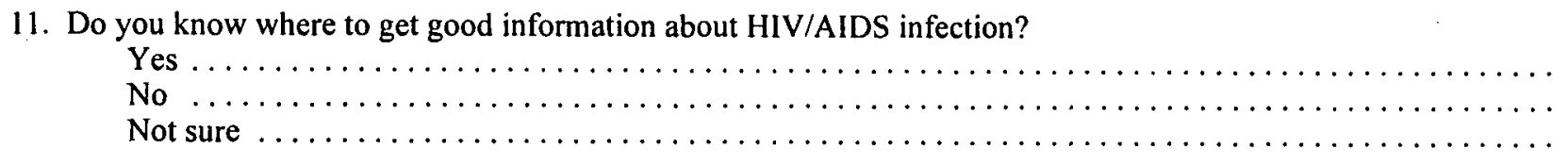 & $\begin{array}{r}58.1 \\
33.0 \\
8.8\end{array}$ & $\begin{array}{l}56.4 \\
30.8 \\
12.9\end{array}$ \\
\hline
\end{tabular}


Table 28. Continued

\begin{tabular}{|c|c|c|}
\hline \multirow{2}{*}{ Belief $\quad$ Item } & \multicolumn{2}{|c|}{ Gender in percent } \\
\hline & Females & Males \\
\hline 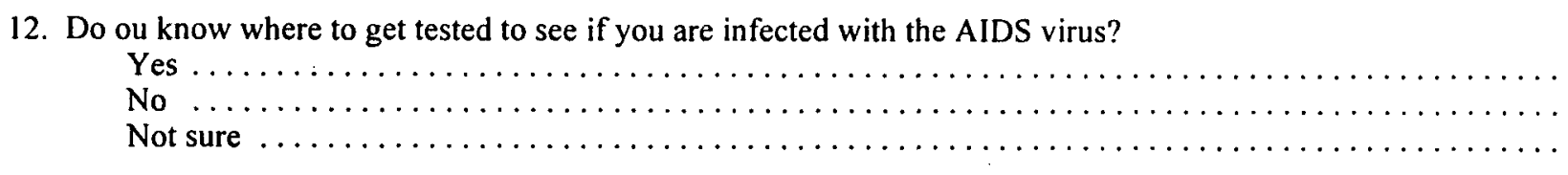 & $\begin{array}{l}62.8 \\
27.1 \\
10.1\end{array}$ & $\begin{array}{r}60.8 \\
30.3 \\
8.9\end{array}$ \\
\hline 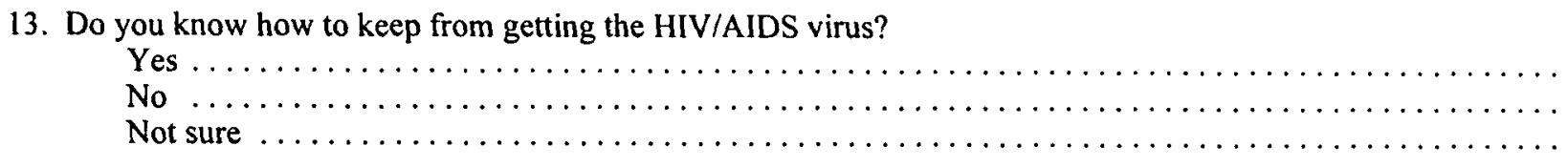 & $\begin{array}{r}89.0 \\
7.7 \\
3.3\end{array}$ & $\begin{array}{r}91.3 \\
4.9 \\
3.8\end{array}$ \\
\hline 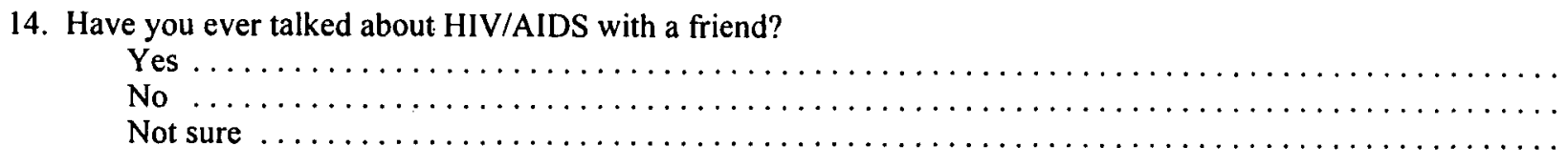 & $\begin{array}{r}67.6 \\
26.4 \\
5.9\end{array}$ & $\begin{array}{r}76.8 \\
20.1 \\
3.1\end{array}$ \\
\hline 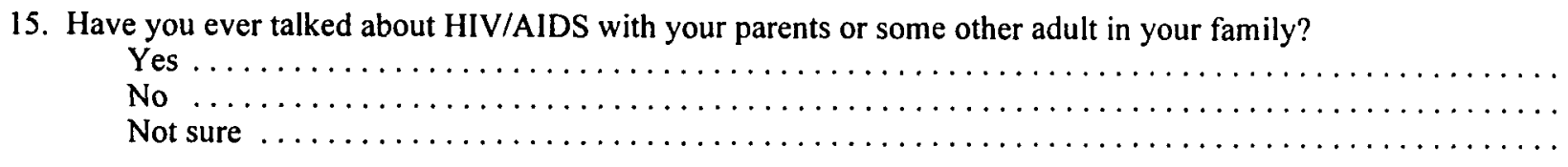 & $\begin{array}{r}63.2 \\
34.1 \\
2.6\end{array}$ & $\begin{array}{r}52.7 \\
42.6 \\
4.7\end{array}$ \\
\hline
\end{tabular}


Table 29. Percentage of HIV/AIDS Related Knowledge by Gender.

\begin{tabular}{|c|c|c|}
\hline \multirow[t]{2}{*}{ Knowledge $\quad$ Item } & \multicolumn{2}{|c|}{ Gender in percent } \\
\hline & Females & Males \\
\hline 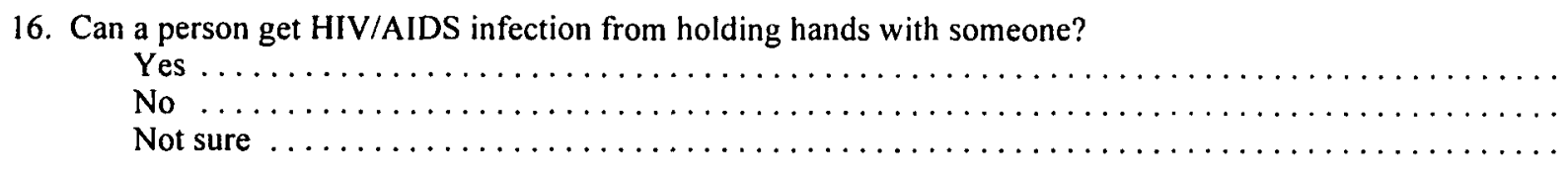 & $\begin{array}{r}7.9 \\
85.2 \\
6.8\end{array}$ & $\begin{array}{r}9.9 \\
81.5 \\
8.6\end{array}$ \\
\hline 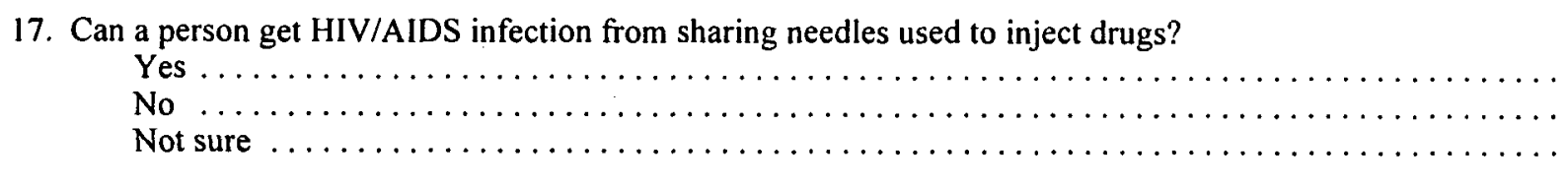 & $\begin{array}{r}90.7 \\
6.4 \\
2.9\end{array}$ & $\begin{array}{r}88.2 \\
8.0 \\
3.8\end{array}$ \\
\hline 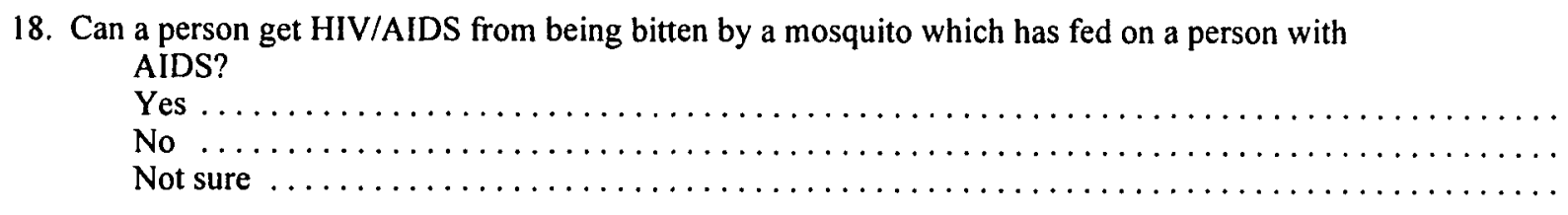 & $\begin{array}{l}51.1 \\
28.2 \\
20.7\end{array}$ & $\begin{array}{l}35.2 \\
44.4 \\
20.4\end{array}$ \\
\hline 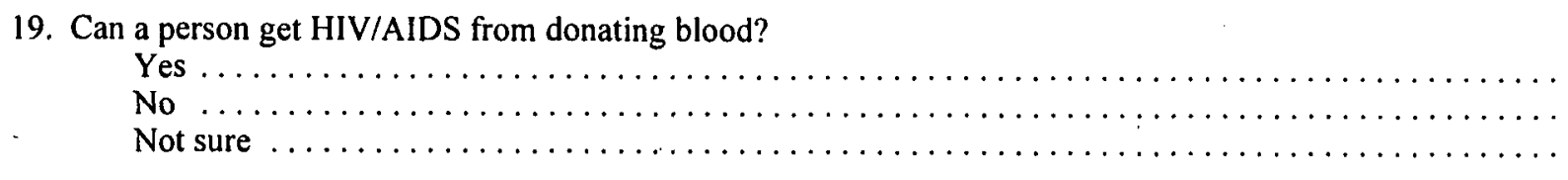 & $\begin{array}{l}55.7 \\
30.2 \\
14.1\end{array}$ & $\begin{array}{l}56.4 \\
33.0 \\
10.7\end{array}$ \\
\hline 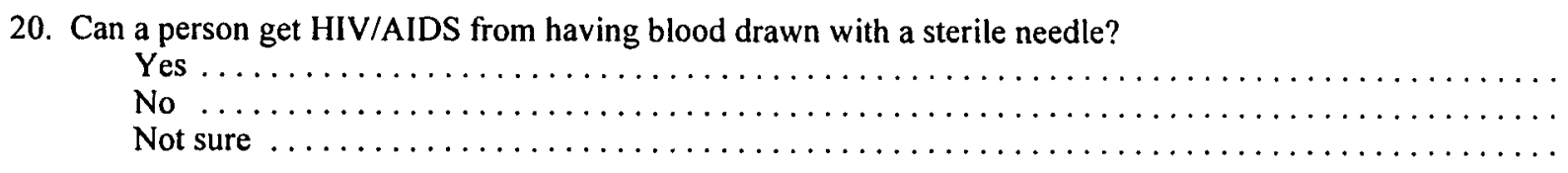 & $\begin{array}{r}33.9 \\
59.9 \\
6.2\end{array}$ & $\begin{array}{r}31.2 \\
61.7 \\
7.1\end{array}$ \\
\hline
\end{tabular}


Table 29. Continued.

\begin{tabular}{|c|c|c|}
\hline \multirow[t]{2}{*}{ Knowledge $\quad$ Item } & \multicolumn{2}{|c|}{ Gender in percent } \\
\hline & Females & Males \\
\hline 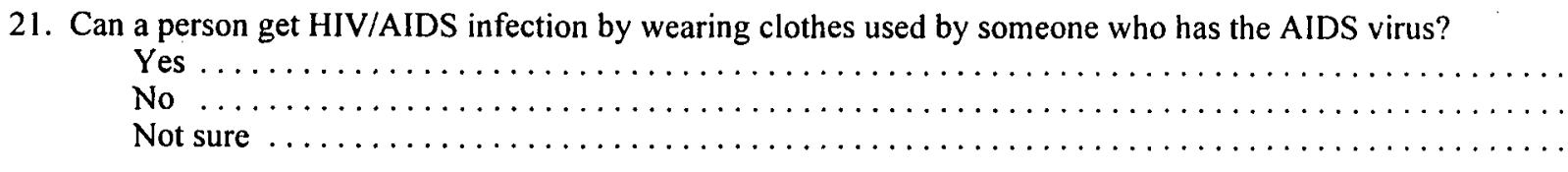 & $\begin{array}{l}14.1 \\
68.9 \\
17.0\end{array}$ & $\begin{array}{l}12.9 \\
71.0 \\
16.1\end{array}$ \\
\hline 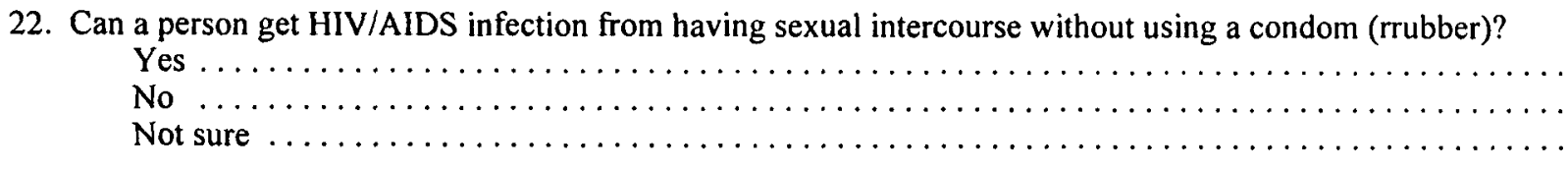 & $\begin{array}{l}66.1 \\
18.7 \\
15.2\end{array}$ & $\begin{array}{l}70.0 \\
16.7 \\
13.3\end{array}$ \\
\hline 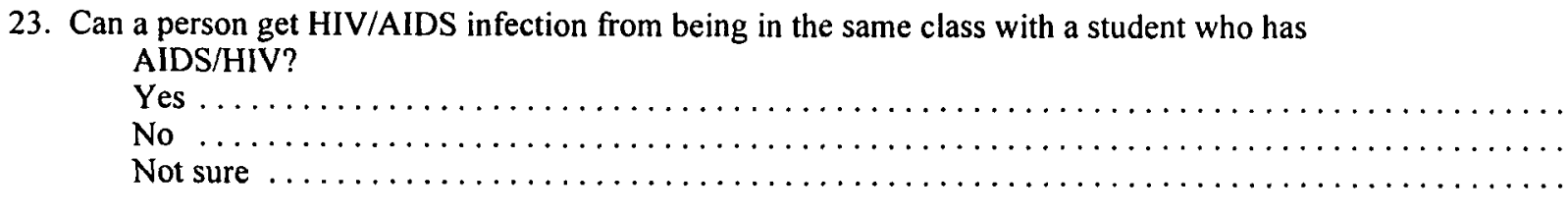 & $\begin{array}{l}10.4 \\
79.1 \\
10.6\end{array}$ & $\begin{array}{r}9.0 \\
80.8 \\
10.2\end{array}$ \\
\hline 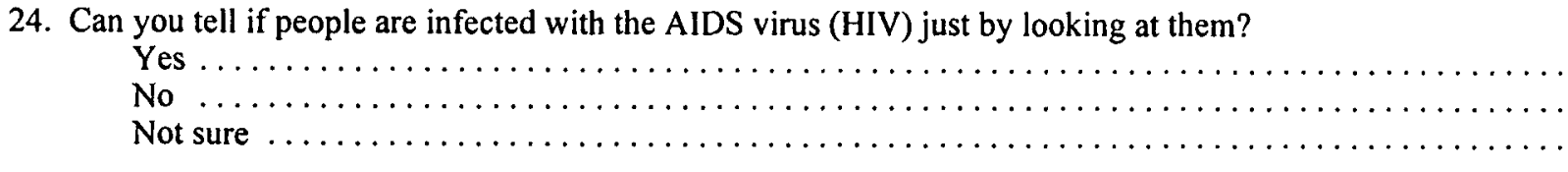 & $\begin{array}{l}17.6 \\
66.5 \\
15.9\end{array}$ & $\begin{array}{l}13.8 \\
71.2 \\
15.1\end{array}$ \\
\hline 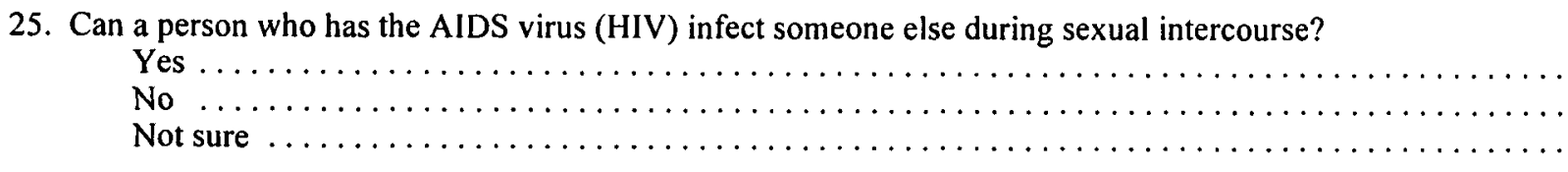 & $\begin{array}{r}85.9 \\
9.7 \\
4.4\end{array}$ & $\begin{array}{r}87.6 \\
8.4 \\
3.8\end{array}$ \\
\hline
\end{tabular}


Table 29. Continued.

\begin{tabular}{|c|c|c|}
\hline \multirow[t]{2}{*}{ Knowledge $\quad$ Item } & \multicolumn{2}{|c|}{ Gender in percent } \\
\hline & Females & Males \\
\hline 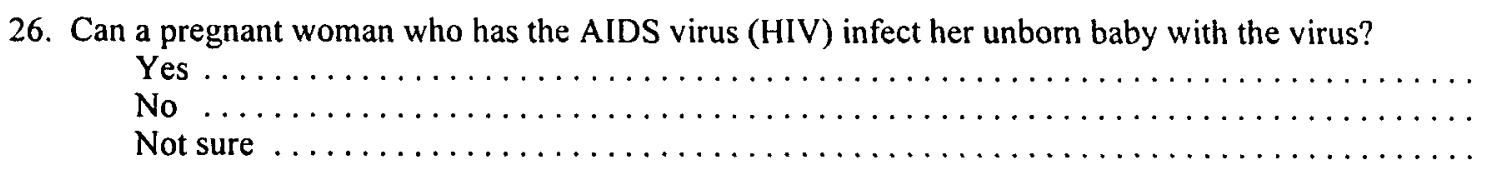 & $\begin{array}{r}87.7 \\
6.6 \\
5.7\end{array}$ & $\begin{array}{r}88.7 \\
6.4 \\
4.9\end{array}$ \\
\hline 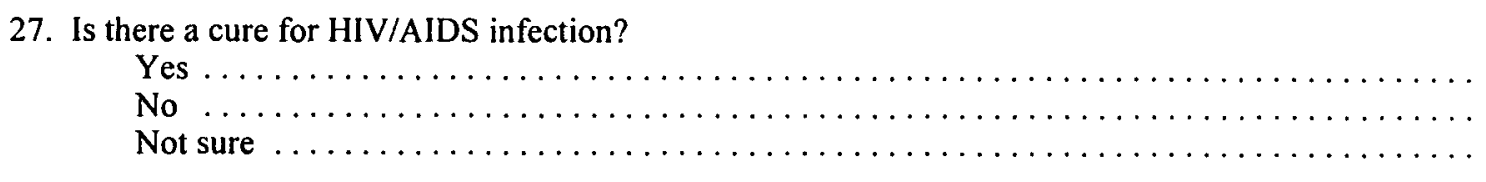 & $\begin{array}{l}24.7 \\
61.9 \\
13.4\end{array}$ & $\begin{array}{l}21.2 \\
67.9 \\
10.9\end{array}$ \\
\hline 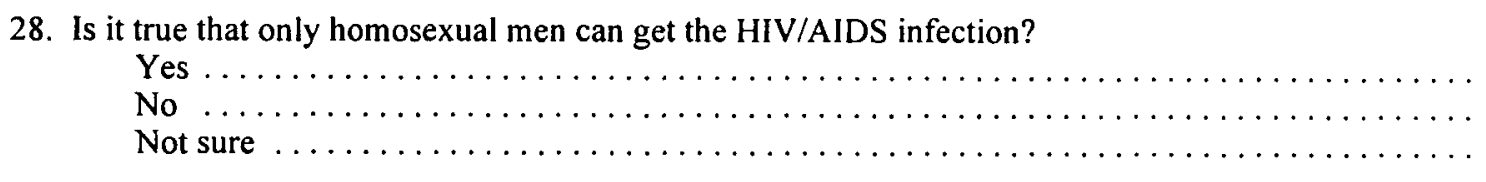 & $\begin{array}{l}25.8 \\
35.7 \\
38.5\end{array}$ & $\begin{array}{l}26.2 \\
48.1 \\
25.7\end{array}$ \\
\hline 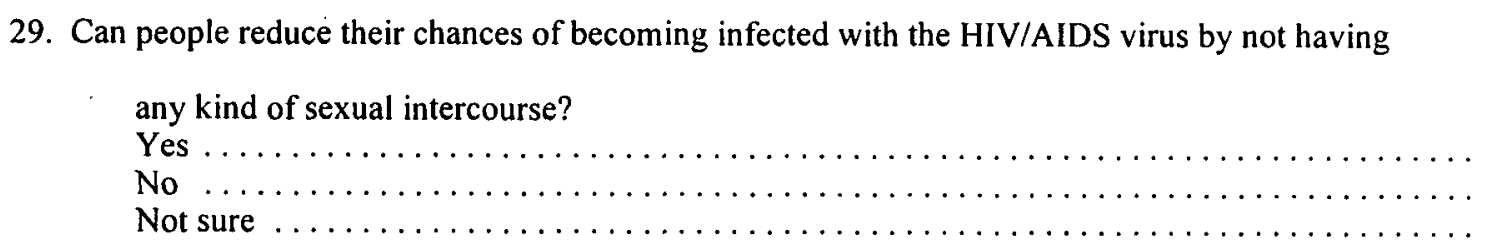 & $\begin{array}{l}47.6 \\
37.9 \\
14.5\end{array}$ & $\begin{array}{l}52.2 \\
32.7 \\
15.1\end{array}$ \\
\hline 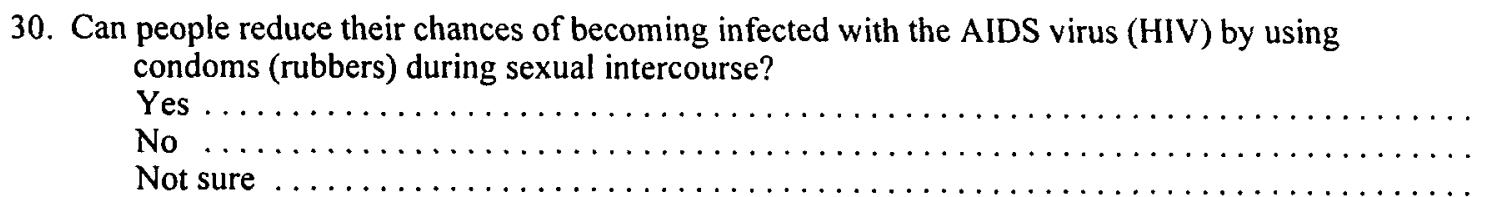 & $\begin{array}{l}66.7 \\
20.5 \\
12.8\end{array}$ & $\begin{array}{l}71.4 \\
16.4 \\
12.1\end{array}$ \\
\hline
\end{tabular}


Table 29. Continued.

\begin{tabular}{|c|c|c|}
\hline \multirow[t]{2}{*}{$\begin{array}{ll}\text { Knowledge } & \text { Item }\end{array}$} & \multicolumn{2}{|c|}{ Gender in percent } \\
\hline & Females & Males \\
\hline 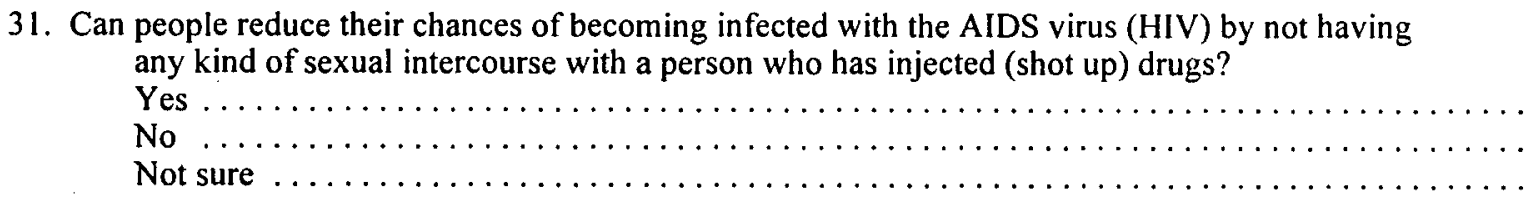 & $\begin{array}{l}28.2 \\
50.7 \\
21.1\end{array}$ & $\begin{array}{l}28.4 \\
52.2 \\
19.4\end{array}$ \\
\hline 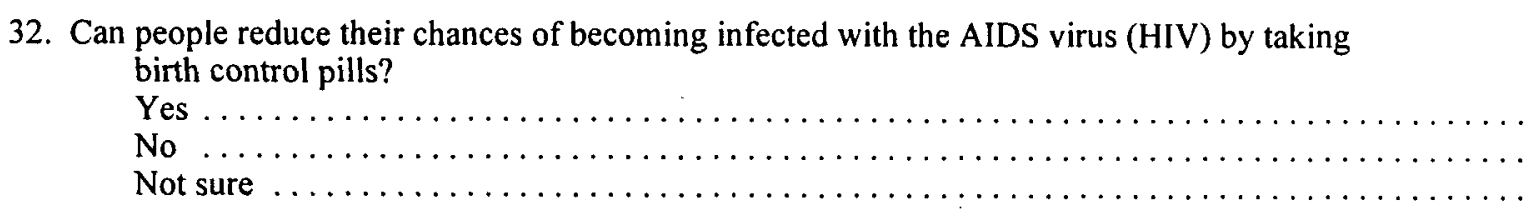 & $\begin{array}{r}11.7 \\
78.6 \\
9.7\end{array}$ & $\begin{array}{r}11.1 \\
81.2 \\
7.7\end{array}$ \\
\hline 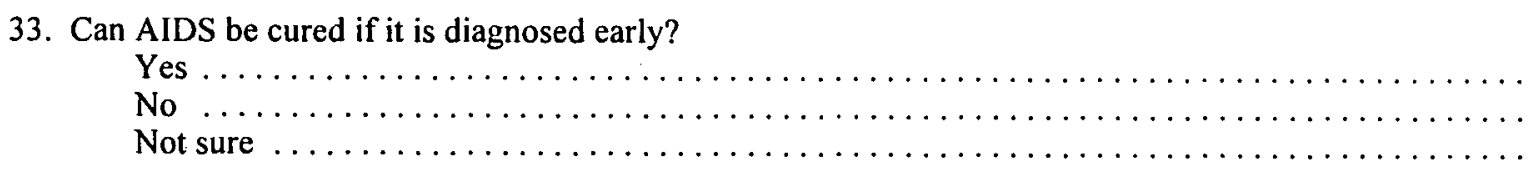 & $\begin{array}{l}14.5 \\
74.4 \\
11.0\end{array}$ & $\begin{array}{r}11.5 \\
78.7 \\
9.8\end{array}$ \\
\hline 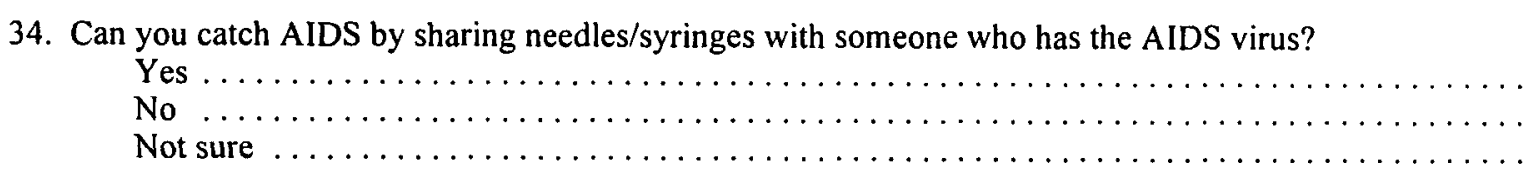 & $\begin{array}{r}83.3 \\
12.8 \\
4.0\end{array}$ & $\begin{array}{r}81.2 \\
14.1 \\
4.7\end{array}$ \\
\hline
\end{tabular}


Table 30. Percentage of HIV/AIDS Related Sexual Behavior by Gender.

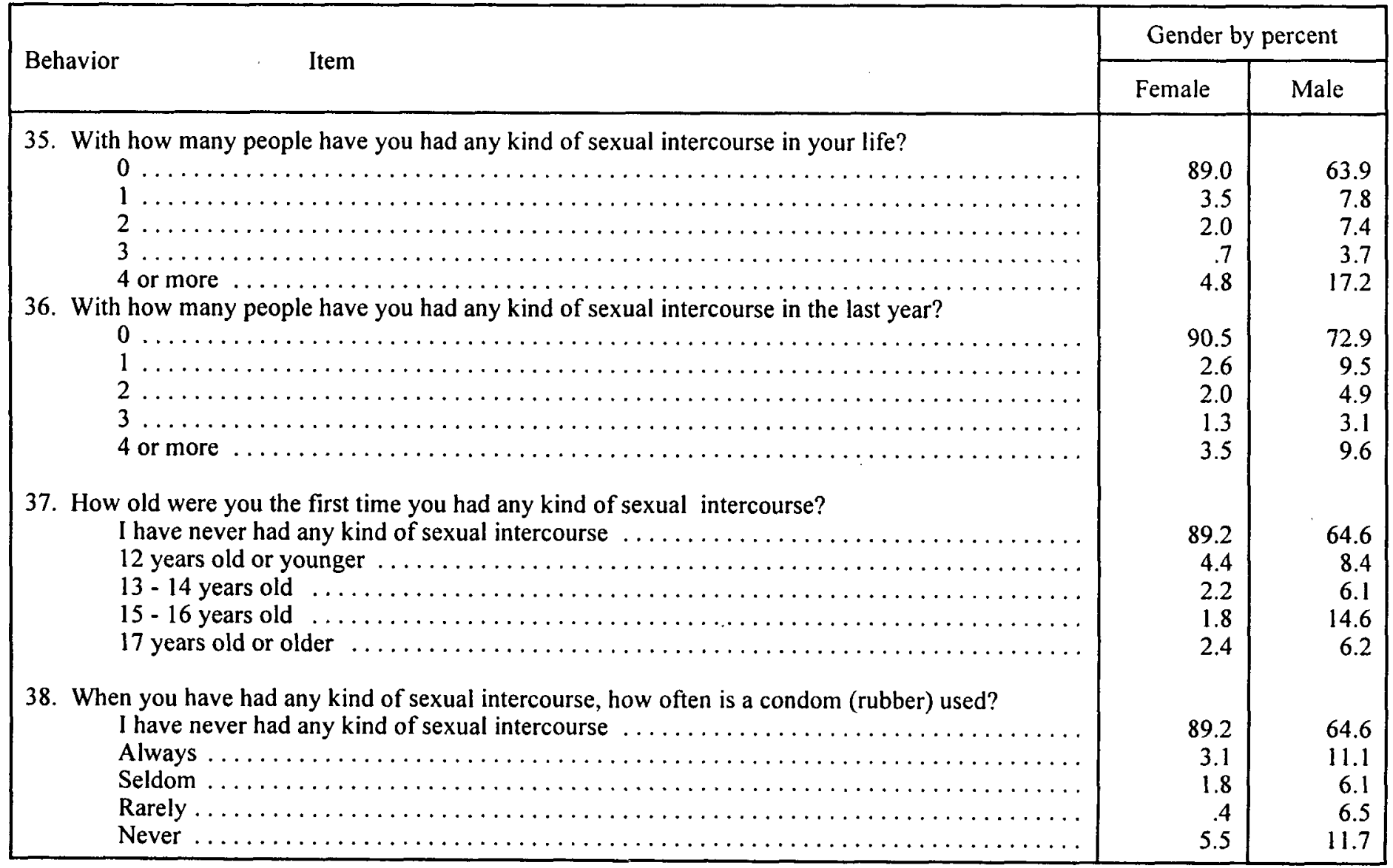


Table 31. Percentage of HIV/AIDS Beliefs by Religious Affiliation

\begin{tabular}{|c|c|c|}
\hline \multirow{2}{*}{ Belief } & \multicolumn{2}{|c|}{ Affiliation in percent } \\
\hline & SDA & Non-SDA \\
\hline 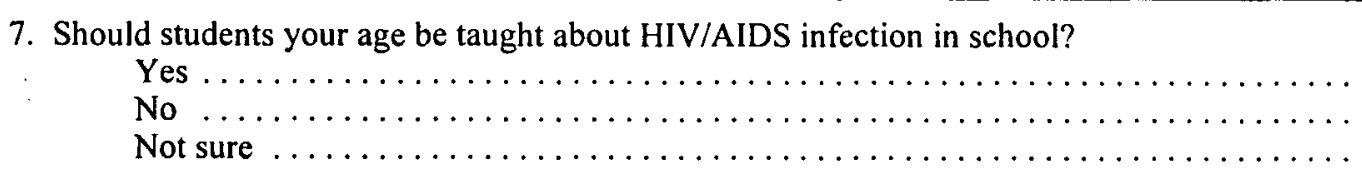 & $\begin{array}{r}94.2 \\
2.9 \\
2.9\end{array}$ & $\begin{array}{r}94.5 \\
3.4 \\
2.1\end{array}$ \\
\hline 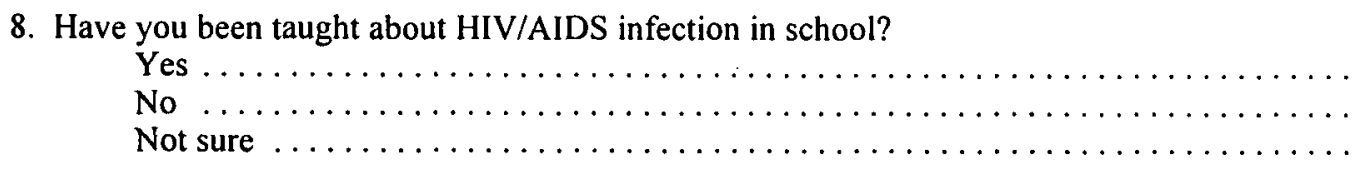 & $\begin{array}{r}79.6 \\
16.4 \\
4.0\end{array}$ & $\begin{array}{r}66.0 \\
29.2 \\
4.8\end{array}$ \\
\hline 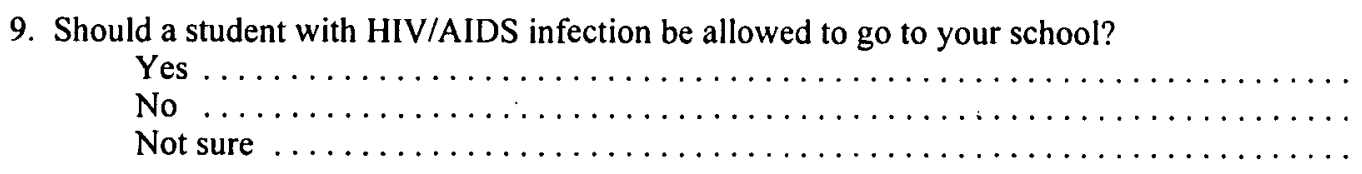 & $\begin{array}{l}42.2 \\
28.9 \\
28.9\end{array}$ & $\begin{array}{l}33.8 \\
25.1 \\
41.1\end{array}$ \\
\hline 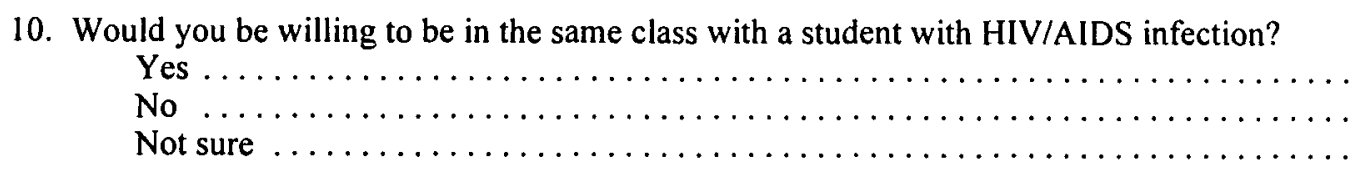 & $\begin{array}{l}50.4 \\
38.5 \\
11.1\end{array}$ & $\begin{array}{l}64.4 \\
23.9 \\
11.7\end{array}$ \\
\hline 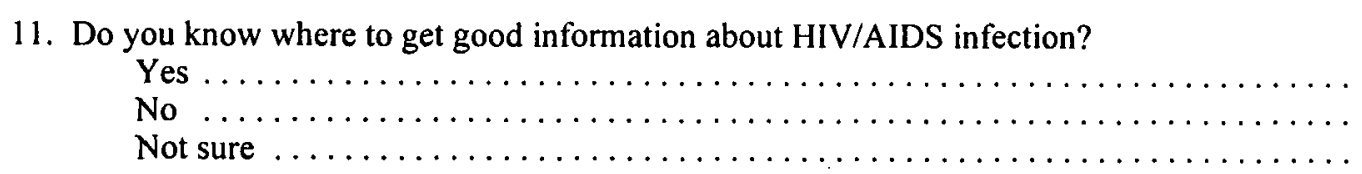 & $\begin{array}{l}57.3 \\
32.4 \\
10.3\end{array}$ & $\begin{array}{l}56.6 \\
31.5 \\
12.0\end{array}$ \\
\hline
\end{tabular}


Table 31. Continued

\begin{tabular}{|c|c|c|}
\hline \multirow{2}{*}{ Belief } & \multicolumn{2}{|c|}{ Affiliation in percent } \\
\hline & SDA & Non-SDA \\
\hline 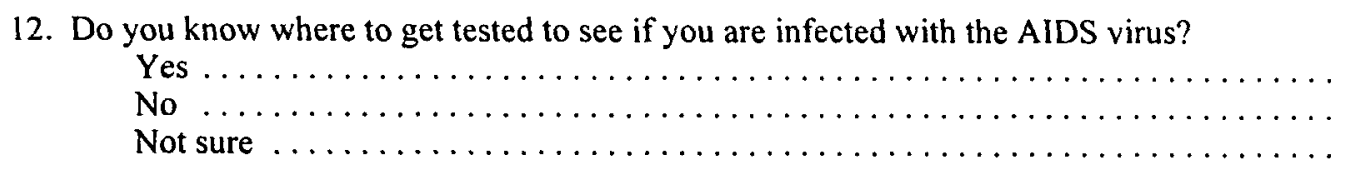 & $\begin{array}{r}66.8 \\
26.3 \\
6.9\end{array}$ & $\begin{array}{l}60.0 \\
29.7 \\
10.3\end{array}$ \\
\hline 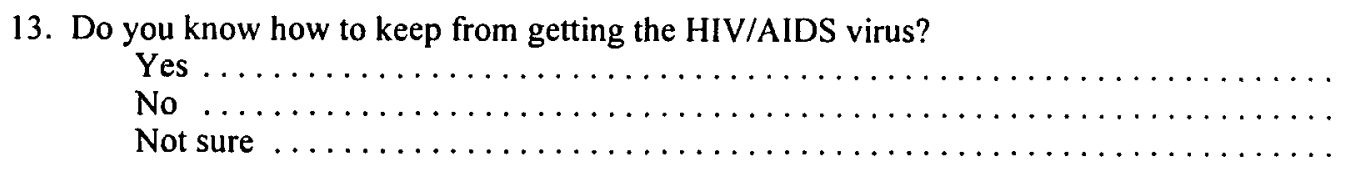 & $\begin{array}{r}91.8 \\
5.8 \\
2.4\end{array}$ & $\begin{array}{r}89.2 \\
6.2 \\
4.6\end{array}$ \\
\hline 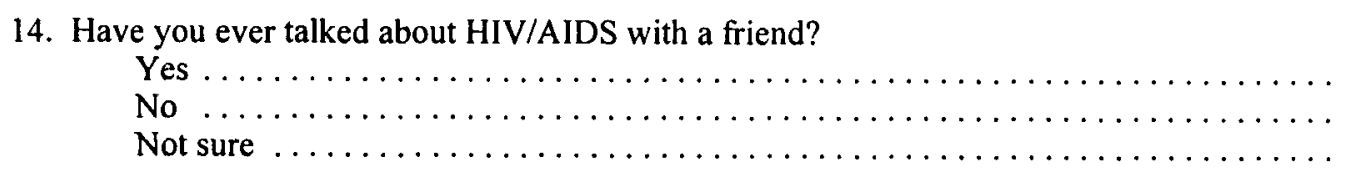 & $\begin{array}{r}77.7 \\
17.5 \\
4.8\end{array}$ & $\begin{array}{r}69.4 \\
26.7 \\
3.9\end{array}$ \\
\hline 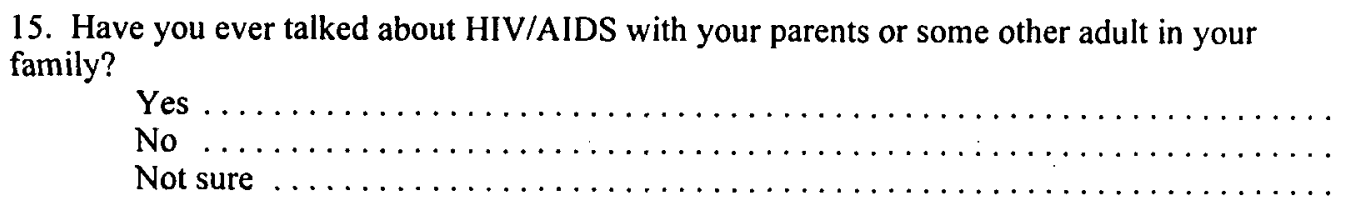 & $\begin{array}{r}63.1 \\
32.1 \\
4.8\end{array}$ & $\begin{array}{r}48.0 \\
47.8 \\
4.1\end{array}$ \\
\hline
\end{tabular}


Table 32. Percentage of HIV/AIDS Related Knowledge by Religious Affiliation

\begin{tabular}{|c|c|c|}
\hline \multirow[t]{2}{*}{ Knowledge $\quad$ Item } & \multicolumn{2}{|c|}{$\begin{array}{l}\text { Religious Affiliatoin } \\
\text { in percent }\end{array}$} \\
\hline & SDA & Non-SDA \\
\hline 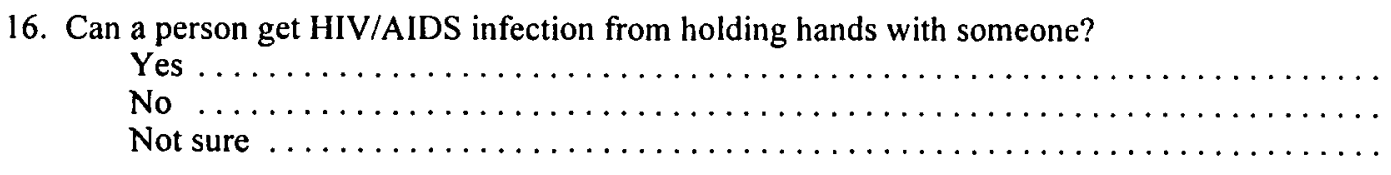 & $\begin{array}{r}11.7 \\
80.6 \\
7.7\end{array}$ & $\begin{array}{r}8.5 \\
84.4 \\
7.1\end{array}$ \\
\hline 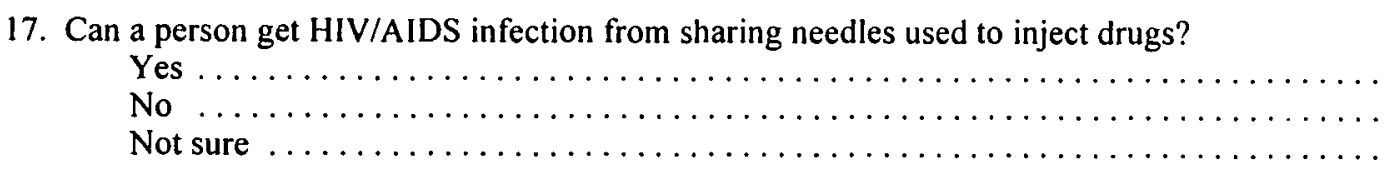 & $\begin{array}{r}88.9 \\
6.9 \\
4.2\end{array}$ & $\begin{array}{r}89.9 \\
6.9 \\
3.2\end{array}$ \\
\hline 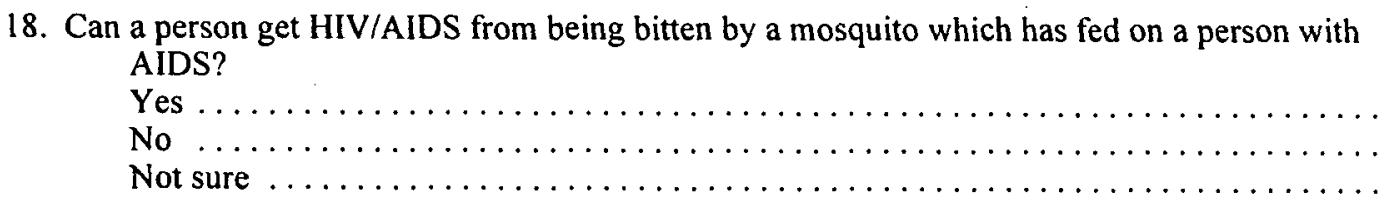 & $\begin{array}{l}41.1 \\
39.0 \\
19.9\end{array}$ & $\begin{array}{l}39.5 \\
38.4 \\
22.1\end{array}$ \\
\hline 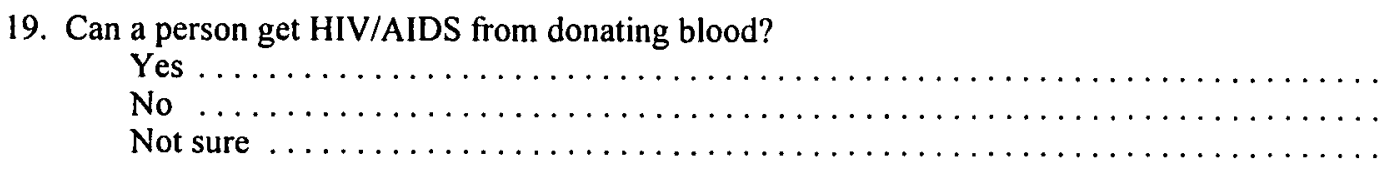 & $\begin{array}{l}67.9 \\
21.5 \\
10.6\end{array}$ & $\begin{array}{l}49.4 \\
36.8 \\
13.8\end{array}$ \\
\hline 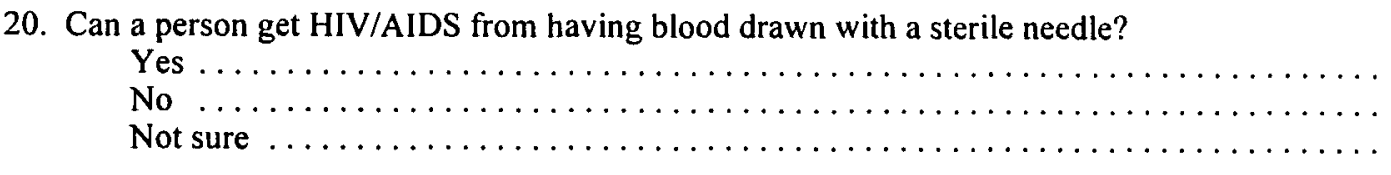 & $\begin{array}{r}40.1 \\
53.8 \\
6.1\end{array}$ & $\begin{array}{r}27.1 \\
65.3 \\
7.6\end{array}$ \\
\hline
\end{tabular}


Table 32. Continued

\begin{tabular}{|c|c|c|}
\hline \multirow[t]{2}{*}{ Knowledge $\quad$ Item } & \multicolumn{2}{|c|}{$\begin{array}{l}\text { Religious Affiliation } \\
\text { in percent }\end{array}$} \\
\hline & SDA & Non-SDA \\
\hline 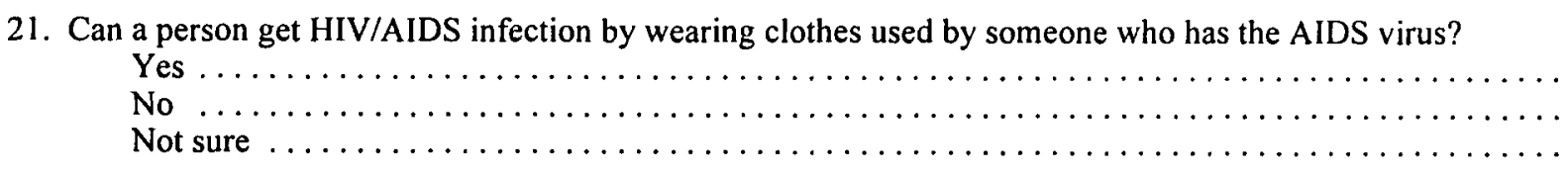 & $\begin{array}{l}18.0 \\
67.1 \\
14.9\end{array}$ & $\begin{array}{l}13.3 \\
70.1 \\
16.6\end{array}$ \\
\hline 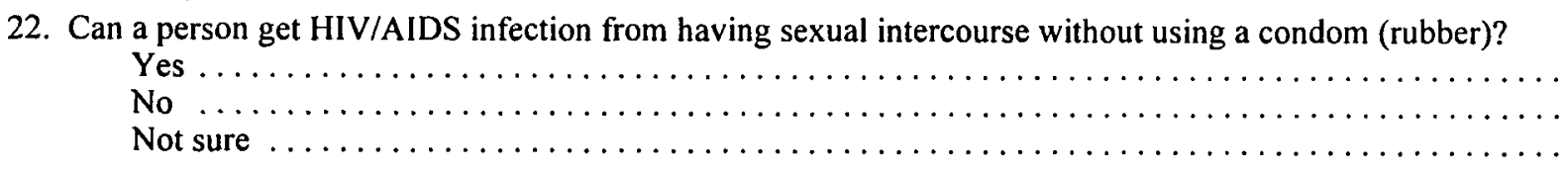 & $\begin{array}{l}70.0 \\
17.0 \\
13.0\end{array}$ & $\begin{array}{l}67.6 \\
18.2 \\
14.3\end{array}$ \\
\hline 23. Can a person get HIV/AIDS infection from being in the same class with a student who has HIV/AIDS? & & \\
\hline 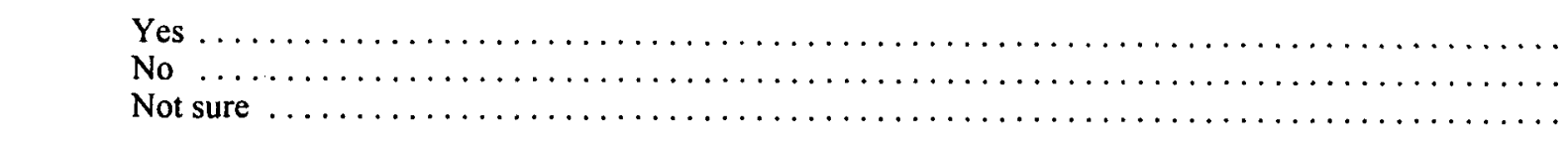 & $\begin{array}{l}10.6 \\
79.0 \\
10.3\end{array}$ & $\begin{array}{r}9.2 \\
81.1 \\
9.7\end{array}$ \\
\hline 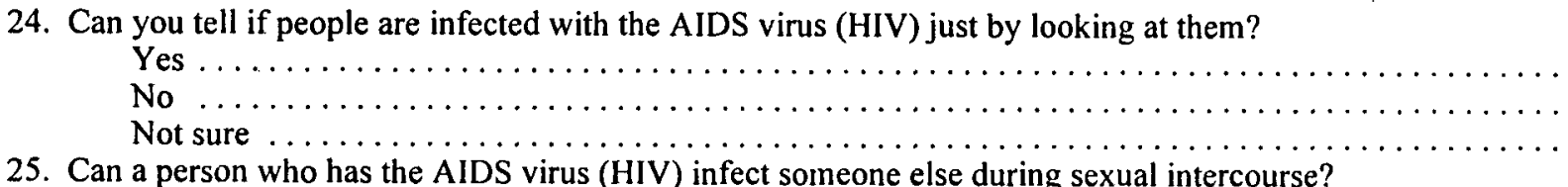 & $\begin{array}{l}17.0 \\
66.0 \\
17.0\end{array}$ & $\begin{array}{l}14.3 \\
70.8 \\
14.9\end{array}$ \\
\hline 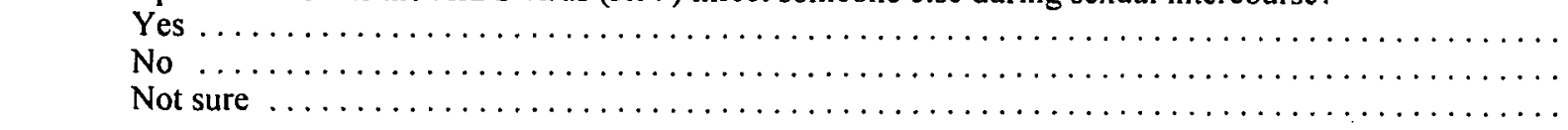 & $\begin{array}{r}85.9 \\
9.5 \\
4.5\end{array}$ & $\begin{array}{r}87.1 \\
8.0 \\
4.6\end{array}$ \\
\hline
\end{tabular}


Table 32. Continued.

\begin{tabular}{|c|c|c|}
\hline \multirow[t]{2}{*}{ Knowledge $\quad$ Item } & \multicolumn{2}{|c|}{$\begin{array}{l}\text { Religious Affiliation } \\
\text { in percent }\end{array}$} \\
\hline & SDA & Non-SDA \\
\hline 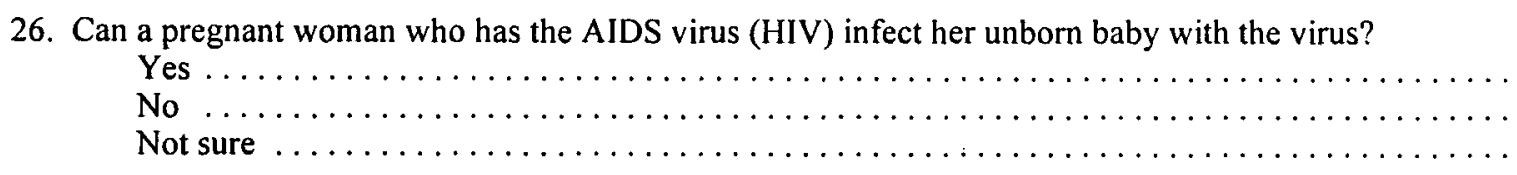 & $\begin{array}{r}85.6 \\
7.7 \\
6.6\end{array}$ & $\begin{array}{r}88.7 \\
6.2 \\
5.1\end{array}$ \\
\hline 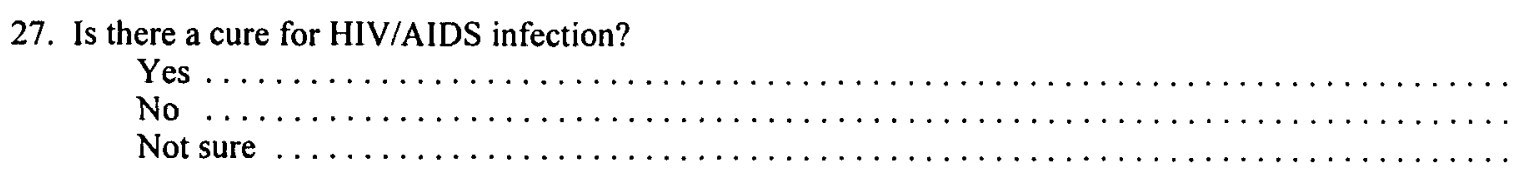 & $\begin{array}{l}23.6 \\
61.5 \\
14.9\end{array}$ & $\begin{array}{l}17.2 \\
71.7 \\
11.0\end{array}$ \\
\hline 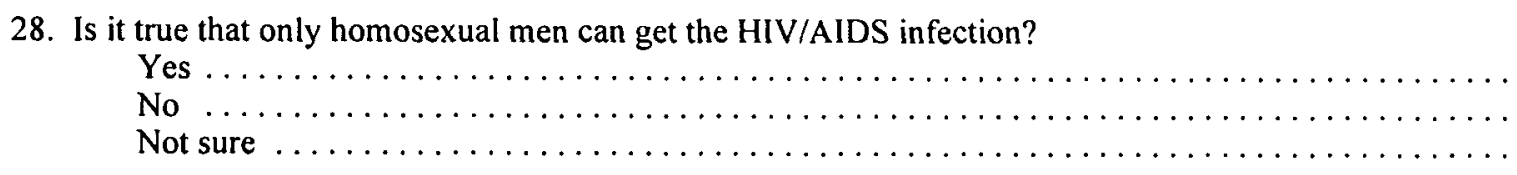 & $\begin{array}{l}34.7 \\
37.4 \\
27.9\end{array}$ & $\begin{array}{l}20.2 \\
48.7 \\
31.0\end{array}$ \\
\hline 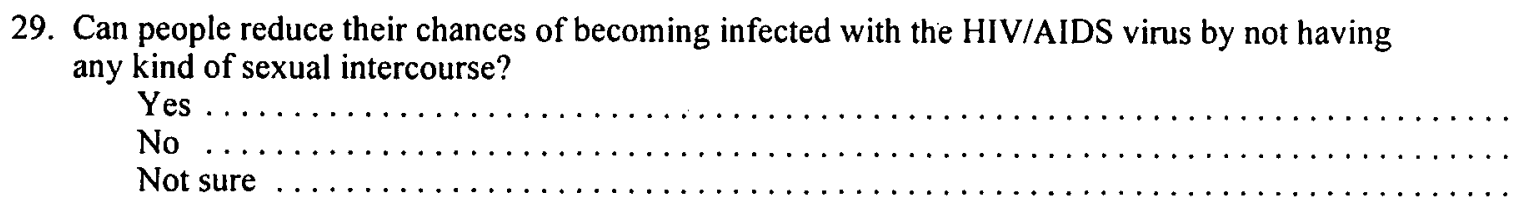 & $\begin{array}{l}52.3 \\
32.1 \\
16.6\end{array}$ & $\begin{array}{l}54.3 \\
33.1 \\
12.6\end{array}$ \\
\hline 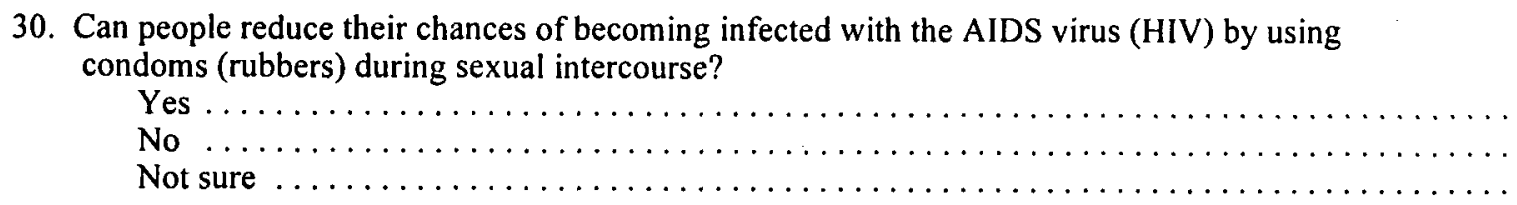 & $\begin{array}{l}63.7 \\
22.3 \\
14.1\end{array}$ & $\begin{array}{l}75.4 \\
14.3 \\
10.3\end{array}$ \\
\hline
\end{tabular}


Table 32. Continued.

\begin{tabular}{|c|c|c|}
\hline \multirow[t]{2}{*}{ Knowledge $\quad$ Item } & \multicolumn{2}{|c|}{$\begin{array}{l}\text { Religious Affiliation in } \\
\text { percent }\end{array}$} \\
\hline & SDA & Non-SDA \\
\hline 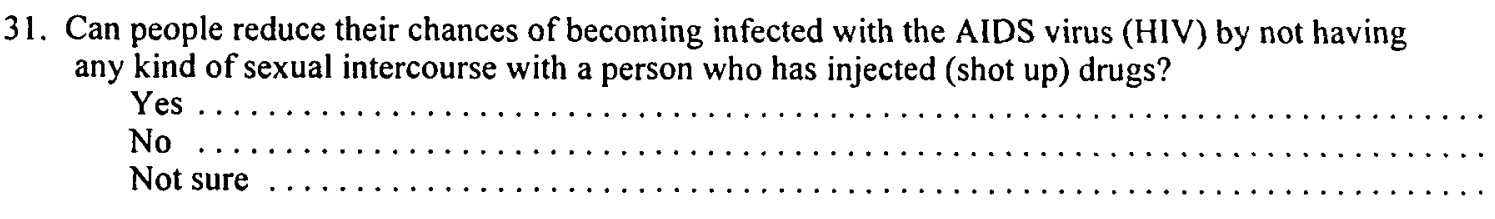 & $\begin{array}{l}28.1 \\
53.1 \\
18.8\end{array}$ & $\begin{array}{l}28.7 \\
50.8 \\
20.5\end{array}$ \\
\hline 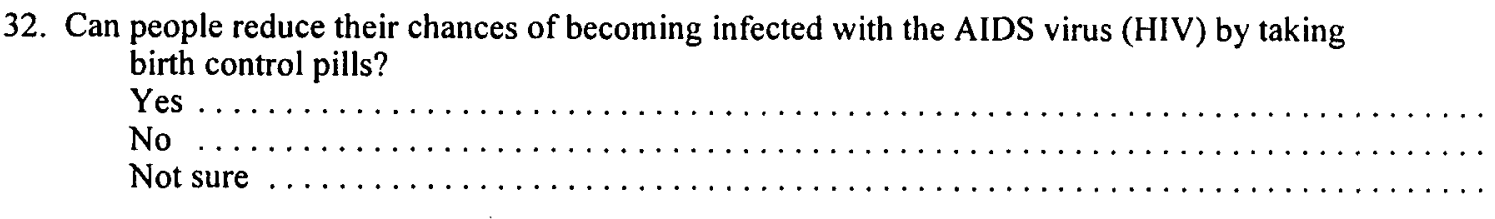 & $\begin{array}{l}11.9 \\
78.0 \\
10.1\end{array}$ & $\begin{array}{r}11.7 \\
81.1 \\
7.1\end{array}$ \\
\hline 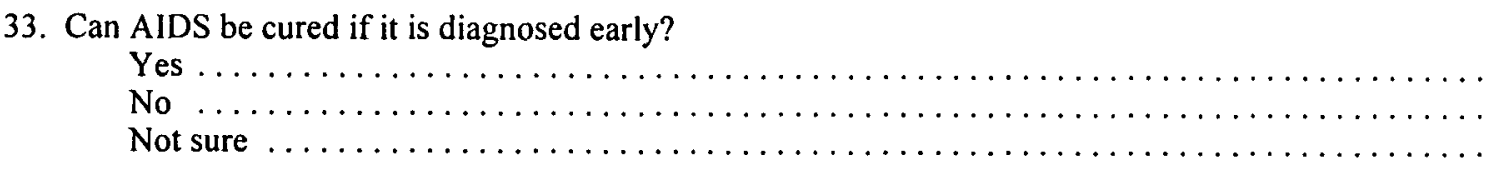 & $\begin{array}{l}13.3 \\
75.1 \\
11.7\end{array}$ & $\begin{array}{r}11.5 \\
78.9 \\
9.7\end{array}$ \\
\hline 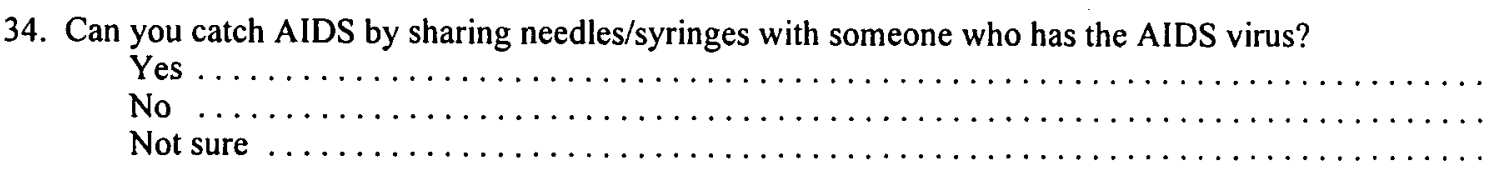 & $\begin{array}{r}75.6 \\
18.0 \\
6.4\end{array}$ & $\begin{array}{r}84.8 \\
10.6 \\
4.6\end{array}$ \\
\hline
\end{tabular}


Table 33. Percentage of HIV/AIDS Related Sexual Behavior by Religious Affiliation.

\begin{tabular}{|c|c|c|}
\hline \multirow{2}{*}{ Behavior $\quad$ Item } & \multicolumn{2}{|c|}{ Affiliation in percent } \\
\hline & SDA & Non-SDA \\
\hline 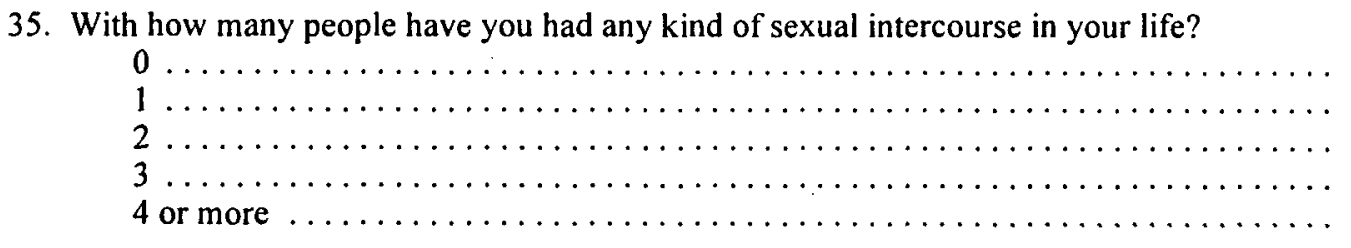 & $\begin{array}{r}71.9 \\
7.2 \\
6.1 \\
2.9 \\
11.9\end{array}$ & $\begin{array}{r}73.1 \\
6.7 \\
5.1 \\
3.2 \\
12.0\end{array}$ \\
\hline 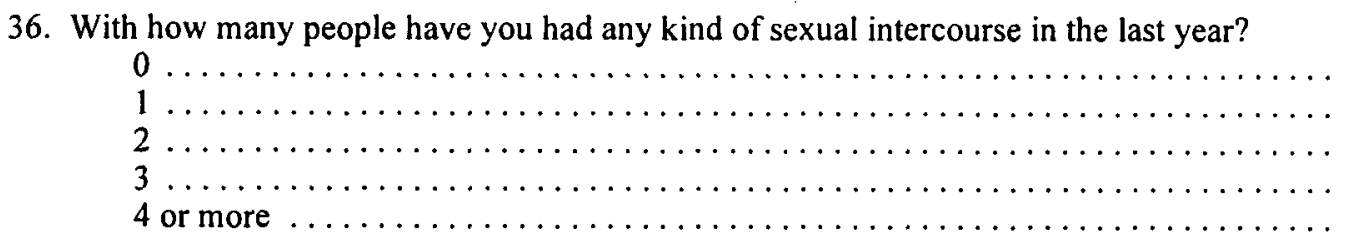 & $\begin{array}{r}80.1 \\
6.6 \\
4.2 \\
2.4 \\
6.6\end{array}$ & $\begin{array}{r}77.5 \\
8.5 \\
3.7 \\
2.5 \\
7.8\end{array}$ \\
\hline 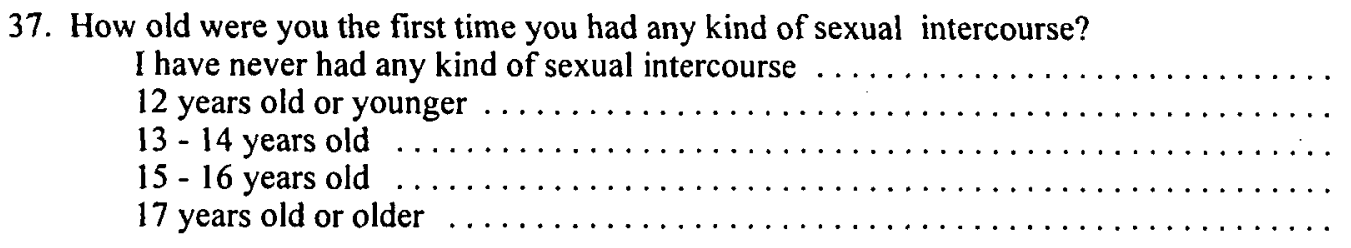 & $\begin{array}{r}72.4 \\
8.2 \\
3.7 \\
11.1 \\
4.5\end{array}$ & $\begin{array}{r}73.6 \\
7.4 \\
4.8 \\
9.2 \\
5.1\end{array}$ \\
\hline 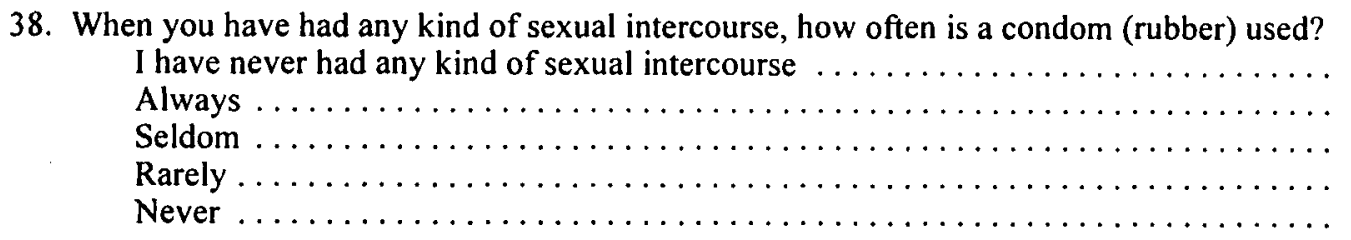 & $\begin{array}{r}73.2 \\
6.6 \\
5.0 \\
4.8 \\
10.3\end{array}$ & $\begin{array}{r}73.6 \\
8.7 \\
4.1 \\
4.1 \\
9.4\end{array}$ \\
\hline
\end{tabular}


Table 34. Percentage of HIV/AIDS Related Belief by Length of Attendance at Seventh-day Adventist Schools

\begin{tabular}{|c|c|c|c|c|}
\hline \multirow{2}{*}{ Belief Item } & \multicolumn{4}{|c|}{ Years in percent } \\
\hline & $0-1$ & $2-6$ & $7-10$ & $11+$ \\
\hline \multicolumn{5}{|l|}{ 7. Should students your age be taught about HIV/AIDS infection in school? } \\
\hline Yes $\ldots \ldots \ldots \ldots \ldots \ldots \ldots \ldots \ldots \ldots \ldots \ldots \ldots$ & 95.0 & 95.5 & 92.7 & 93.2 \\
\hline No ..... & 3.9 & 1.2 & 5.9 & 3.4 \\
\hline Not sure & 1.1 & 3.2 & 1.4 & 3.4 \\
\hline \multicolumn{5}{|l|}{ 8. Have you been taught about HIV/AIDS infection in school? } \\
\hline$\ldots \ldots \ldots \ldots \ldots \ldots$ & 71.4 & 74.4 & 68.5 & 76.2 \\
\hline No . & 26.8 & 20.1 & 26.5 & 19.7 \\
\hline Not sure & 1.8 & 5.5 & 5.0 & 4.1 \\
\hline \multicolumn{5}{|l|}{ 9. Should a student with HIV/AIDS infection be allowed to go to your school? } \\
\hline Yes ... & 40.7 & 37.5 & 34.7 & 35.4 \\
\hline No. & 25.4 & 23.3 & 28.3 & 29.9 \\
\hline Not sure & 33.9 & 39.1 & 37.0 & 34.7 \\
\hline \multicolumn{5}{|l|}{ 10. Would you be willing to be in the same class with a student with HIV/AIDS infection? } \\
\hline 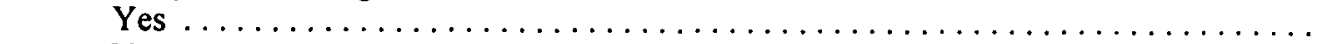 & 59.6 & 59.4 & 55.3 & 49.7 \\
\hline+5 & 30.0 & 26.6 & 34.2 & 38.1 \\
\hline Not sure & 10.4 & 14.0 & 10.5 & 12.2 \\
\hline \multicolumn{5}{|l|}{ 11. Do you know where to get good information about HIV/AIDS infection? } \\
\hline 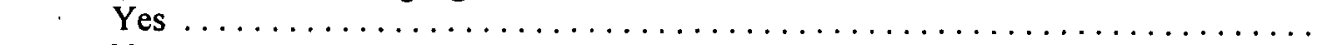 & 61.4 & 53.8 & 57.1 & 60.5 \\
\hline No. & 29.6 & 33.1 & 33.8 & 27.9 \\
\hline Not sure $\ldots \ldots \ldots$. & 8.9 & 13.2 & 9.1 & 11.6 \\
\hline
\end{tabular}


Table 34. Continued

\begin{tabular}{|c|c|c|c|c|}
\hline \multirow{2}{*}{ Belief Item } & \multicolumn{4}{|c|}{ Years in percent } \\
\hline & $0-1$ & $2-6$ & $7-10$ & $11+$ \\
\hline \multicolumn{5}{|l|}{ 12. Do you know where to get tested to see if you are infected with the AIDS virus? } \\
\hline 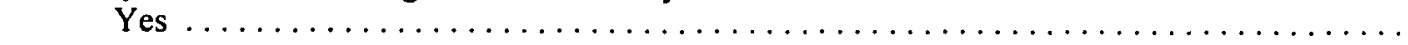 & 62.5 & 60.2 & 62.6 & 62.6 \\
\hline$\ldots \ldots \ldots \ldots \ldots \ldots \ldots \ldots$ & 29.6 & 29.6 & 27.9 & 27.2 \\
\hline Not sure & 7.9 & 10.1 & 9.6 & 10.2 \\
\hline \multicolumn{5}{|l|}{ 13. Do you know how to keep from getting the HIV/AIDS virus? } \\
\hline$\ldots \ldots \ldots \ldots \ldots \ldots$ & 90.7 & 89.7 & 90.0 & 91.8 \\
\hline No . & 5.4 & 6.9 & 5.9 & 4.1 \\
\hline Not sure $\ldots$. & 3.9 & 3.4 & 4.1 & 4.1 \\
\hline \multicolumn{5}{|l|}{ 14. Have you ever talked about HIV/AIDS with a friend? } \\
\hline Yes & 70.7 & 74.8 & 72.1 & 74.8 \\
\hline No . & 26.1 & 4.7 & 24.2 & 19.0 \\
\hline Not sure & 3.2 & 20.5 & 3.7 & 6.1 \\
\hline \multicolumn{5}{|l|}{ 15. Have you ever talked about HIV/AIDS with your parents or some other adult in your family? } \\
\hline Yes & 51.4 & 60.0 & 53.9 & 59.9 \\
\hline ( & 46.1 & 36.9 & 38.8 & 34.0 \\
\hline Not sure $\ldots \ldots \ldots$ & 2.5 & 3.0 & 7.3 & 6.1 \\
\hline
\end{tabular}


Table 35. Percentage of HIV/AIDS Related Knowledge by Length of Attendance at Seventh-day Adventist Schools

\begin{tabular}{|c|c|c|c|c|}
\hline \multirow[t]{2}{*}{ Knowledge Item } & \multicolumn{4}{|c|}{ Years in percent } \\
\hline & $0-1$ & $2-6$ & $7-10$ & $11+$ \\
\hline 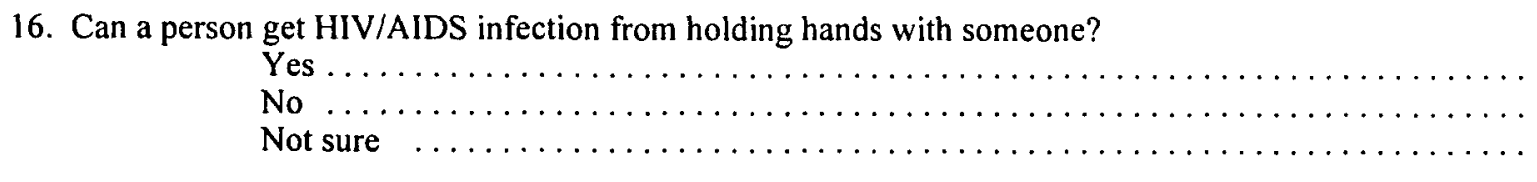 & $\begin{array}{r}8.6 \\
85.4 \\
6.1\end{array}$ & $\begin{array}{r}6.9 \\
85.4 \\
7.7\end{array}$ & $\begin{array}{r}15.5 \\
75.8 \\
8.7\end{array}$ & $\begin{array}{r}9.5 \\
79.6 \\
10.9\end{array}$ \\
\hline 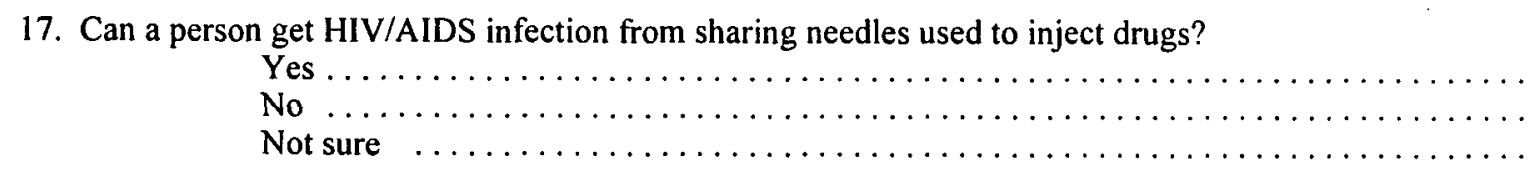 & $\begin{array}{r}87.9 \\
9.3 \\
2.9\end{array}$ & $\begin{array}{r}90.5 \\
5.7 \\
3.9\end{array}$ & $\begin{array}{r}84.5 \\
11.9 \\
3.7\end{array}$ & $\begin{array}{r}95.2 \\
2.0 \\
2.7\end{array}$ \\
\hline 18. Can a person get HIV/AIDS from being bitten by a mosquito which has fed on a person with AIDS? & & & & \\
\hline 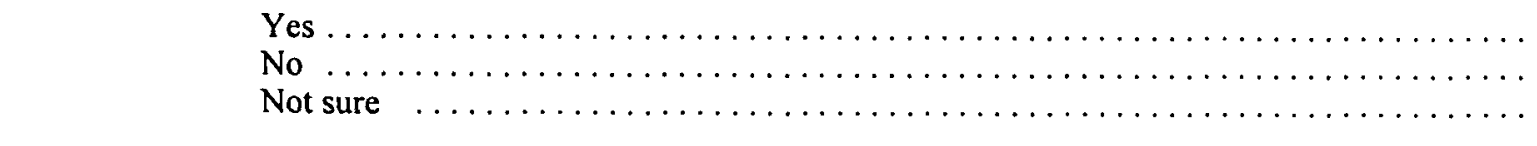 & $\begin{array}{l}46.1 \\
38.2 \\
15.7\end{array}$ & $\begin{array}{l}39.4 \\
39.6 \\
21.1\end{array}$ & $\begin{array}{l}44.3 \\
35.2 \\
20.5\end{array}$ & $\begin{array}{l}35.4 \\
35.4 \\
29.3\end{array}$ \\
\hline 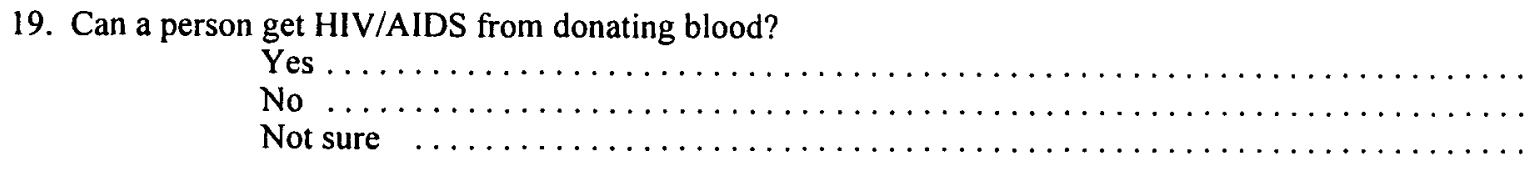 & $\begin{array}{l}52.9 \\
35.7 \\
11.4\end{array}$ & $\begin{array}{l}55.2 \\
32.9 \\
12.0\end{array}$ & $\begin{array}{l}57.5 \\
29.2 \\
13.2\end{array}$ & $\begin{array}{l}61.9 \\
25.2 \\
12.9\end{array}$ \\
\hline 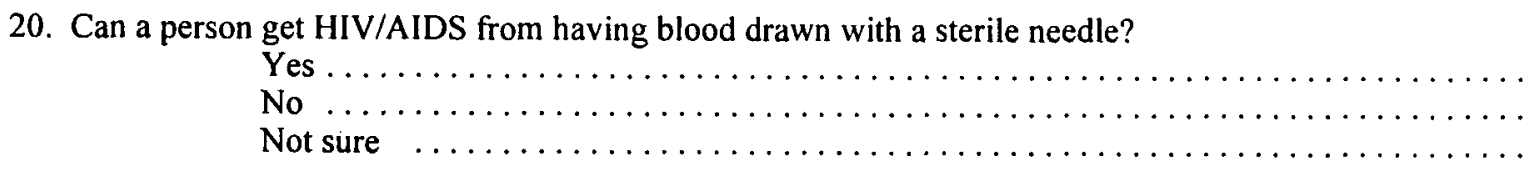 & $\begin{array}{r}30.7 \\
64.3 \\
5.0\end{array}$ & $\begin{array}{r}29.6 \\
64.5 \\
5.9\end{array}$ & $\begin{array}{r}37.9 \\
55.7 \\
6.4\end{array}$ & $\begin{array}{l}35.4 \\
51.7 \\
12.9\end{array}$ \\
\hline
\end{tabular}


Table 35. Continued

\begin{tabular}{|c|c|c|c|c|}
\hline \multirow[t]{2}{*}{ Knowledge Item } & \multicolumn{4}{|c|}{ Years in percent } \\
\hline & $0-1$ & $2-6$ & $7-10$ & $11+$ \\
\hline 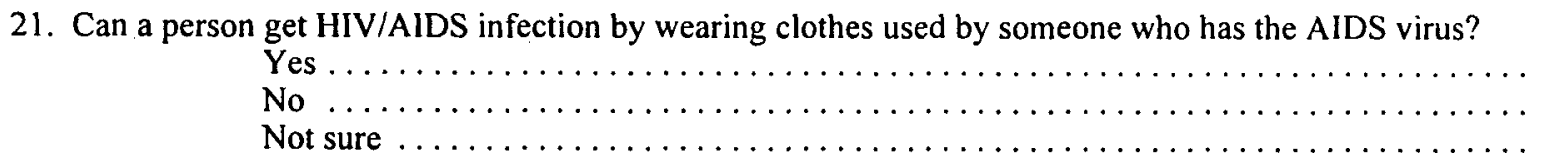 & $\begin{array}{l}12.9 \\
73.9 \\
13.2\end{array}$ & $\begin{array}{r}9.7 \\
71.0 \\
19.3\end{array}$ & $\begin{array}{l}21.5 \\
65.8 \\
12.8\end{array}$ & $\begin{array}{l}15.6 \\
66.0 \\
18.4\end{array}$ \\
\hline $\begin{array}{l}\text { 22. Can a person get HIV/AIDS infection from having sexual intercourse without using a condom } \\
\text { (rubber)? }\end{array}$ & & & & \\
\hline 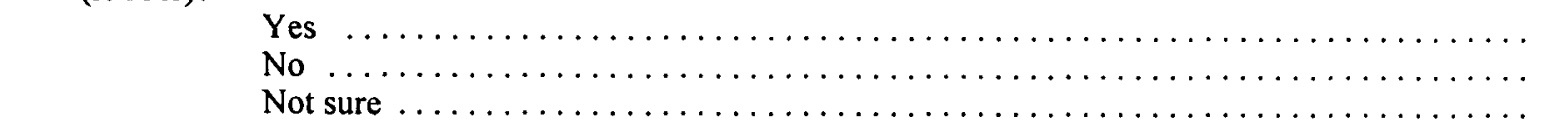 & $\begin{array}{l}67.1 \\
19.3 \\
13.6\end{array}$ & $\begin{array}{l}70.0 \\
16.2 \\
13.8\end{array}$ & $\begin{array}{l}65.3 \\
20.1 \\
14.6\end{array}$ & $\begin{array}{l}70.7 \\
14.3 \\
15.0\end{array}$ \\
\hline 23. Can a person get HIV/AIDS infection from being in the same class with a student who has AIDS/HIV? & & & & \\
\hline 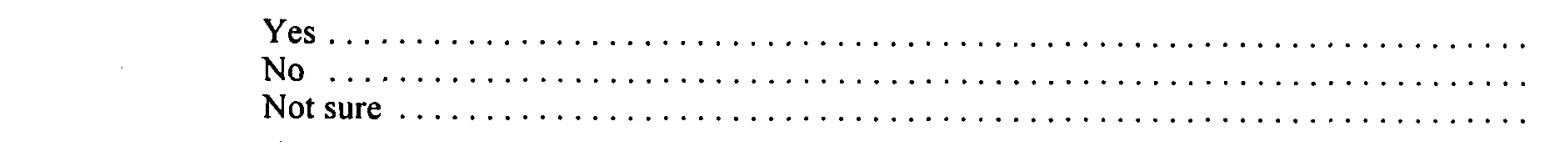 & $\begin{array}{r}8.2 \\
82.1 \\
9.6\end{array}$ & $\begin{array}{r}8.3 \\
80.7 \\
11.0\end{array}$ & $\begin{array}{r}15.1 \\
76.3 \\
8.7\end{array}$ & $\begin{array}{r}8.2 \\
80.3 \\
11.6\end{array}$ \\
\hline 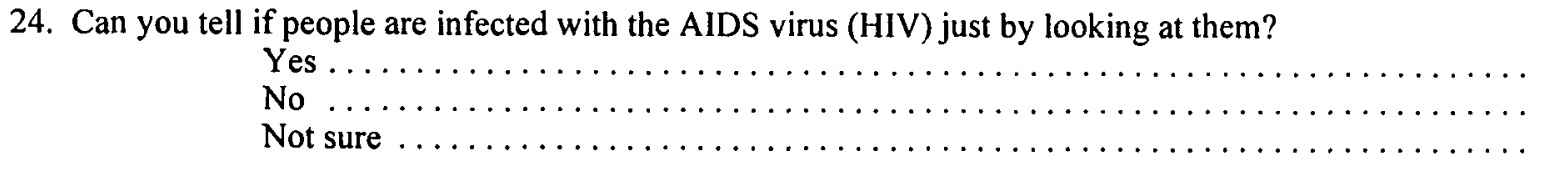 & $\begin{array}{l}15.7 \\
73.2 \\
11.1\end{array}$ & $\begin{array}{l}11.8 \\
72.4 \\
15.8\end{array}$ & $\begin{array}{l}24.7 \\
57.5 \\
17.8\end{array}$ & $\begin{array}{l}13.6 \\
67.3 \\
19.0\end{array}$ \\
\hline 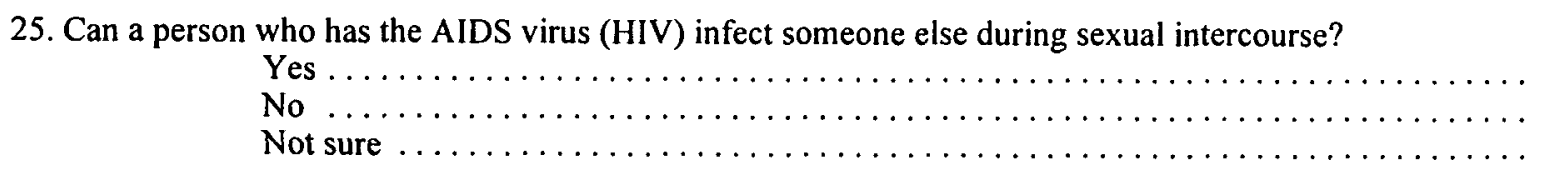 & $\begin{array}{r}86.4 \\
10.4 \\
3.2\end{array}$ & $\begin{array}{r}87.6 \\
8.9 \\
3.2\end{array}$ & $\begin{array}{r}85.8 \\
8.7 \\
5.5\end{array}$ & $\begin{array}{r}87.1 \\
6.8 \\
6.1\end{array}$ \\
\hline
\end{tabular}


Table 35. Continued

\begin{tabular}{|c|c|c|c|c|}
\hline \multirow[t]{2}{*}{ Knowledge $\quad$ Item } & \multicolumn{4}{|c|}{ Years in percent } \\
\hline & $0-1$ & $2-6$ & $7-10$ & $11+$ \\
\hline 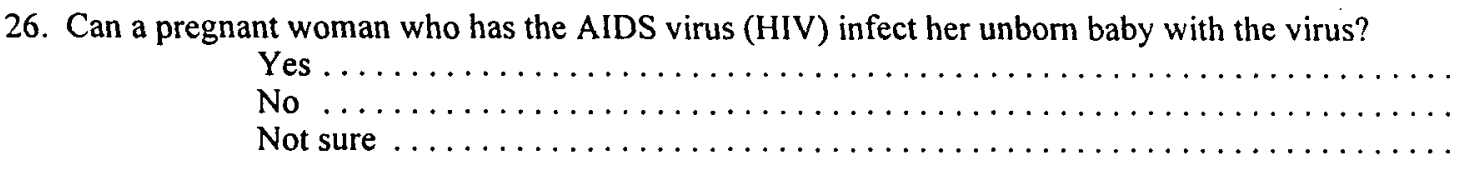 & $\begin{array}{r}87.1 \\
8.2 \\
4.6\end{array}$ & $\begin{array}{r}91.1 \\
5.3 \\
3.7\end{array}$ & $\begin{array}{r}83.5 \\
9.6 \\
6.9\end{array}$ & $\begin{array}{r}87.8 \\
2.7 \\
9.5\end{array}$ \\
\hline 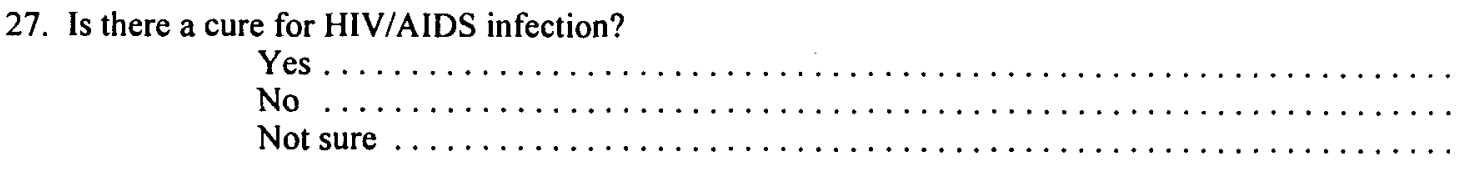 & $\begin{array}{l}18.9 \\
68.9 \\
12.1\end{array}$ & $\begin{array}{l}24.5 \\
64.9 \\
10.5\end{array}$ & $\begin{array}{l}26.5 \\
60.7 \\
12.8\end{array}$ & $\begin{array}{l}16.3 \\
69.4 \\
14.3\end{array}$ \\
\hline 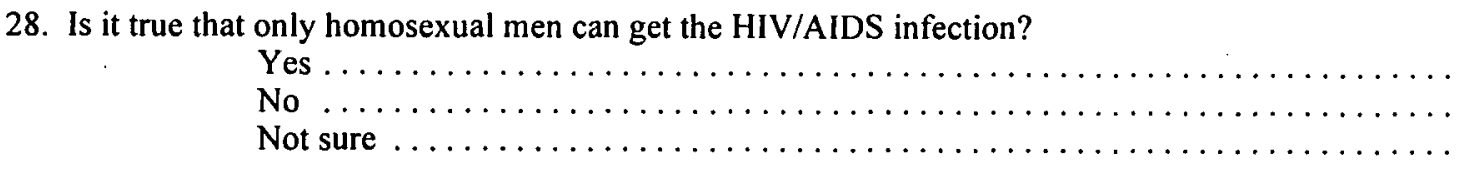 & $\begin{array}{l}30.4 \\
37.9 \\
31.8\end{array}$ & $\begin{array}{l}22.3 \\
49.9 \\
27.8\end{array}$ & $\begin{array}{l}32.0 \\
35.2 \\
32.9\end{array}$ & $\begin{array}{l}21.1 \\
43.5 \\
35.4\end{array}$ \\
\hline 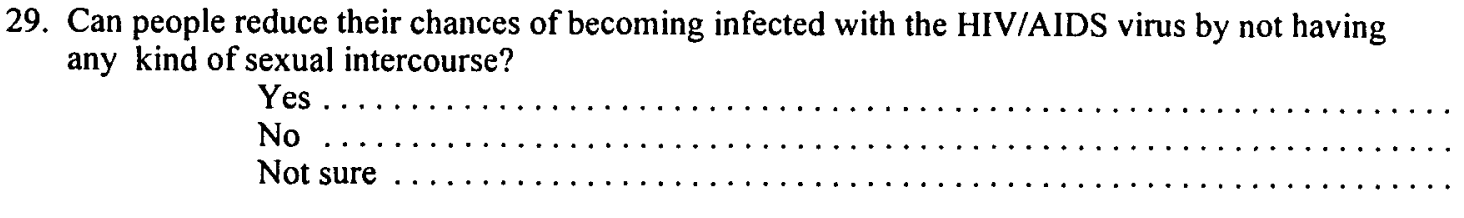 & $\begin{array}{l}48.6 \\
37.1 \\
14.3\end{array}$ & $\begin{array}{l}52.7 \\
32.3 \\
15.0\end{array}$ & $\begin{array}{l}50.7 \\
36.5 \\
12.8\end{array}$ & $\begin{array}{l}44.9 \\
35.4 \\
19.7\end{array}$ \\
\hline 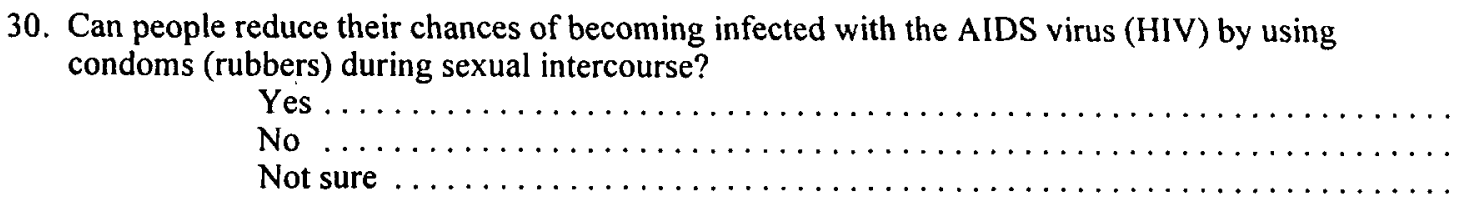 & $\begin{array}{r}73.2 \\
18.6 \\
8.2\end{array}$ & $\begin{array}{l}74.6 \\
13.6 \\
11.8\end{array}$ & $\begin{array}{l}64.8 \\
21.5 \\
13.7\end{array}$ & $\begin{array}{l}53.1 \\
27.9 \\
19.0\end{array}$ \\
\hline
\end{tabular}


Table 35. Continued

\begin{tabular}{|c|c|c|c|c|}
\hline \multirow[t]{2}{*}{ Knowledge } & \multicolumn{4}{|c|}{ Years in percent } \\
\hline & $0-1$ & $2-6$ & $7-10$ & $11+$ \\
\hline 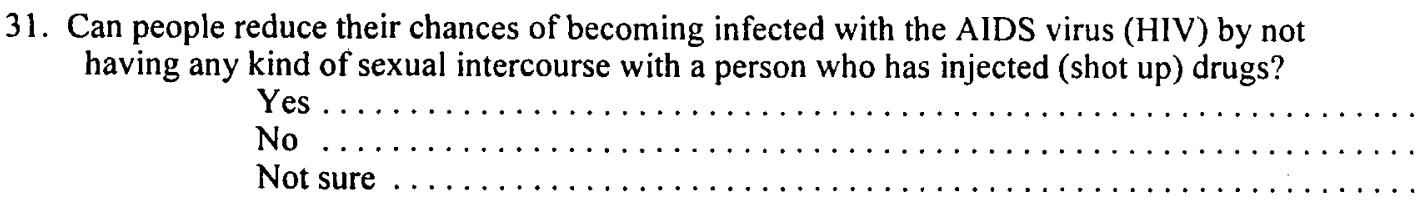 & $\begin{array}{l}30.4 \\
53.6 \\
16.1\end{array}$ & $\begin{array}{l}26.4 \\
51.5 \\
22.1\end{array}$ & $\begin{array}{l}30.6 \\
52.1 \\
17.4\end{array}$ & $\begin{array}{l}26.5 \\
46.9 \\
26.5\end{array}$ \\
\hline \multicolumn{5}{|l|}{$\begin{array}{l}\text { 32. Can people reduce their chances of becoming infected with the AIDS virus (HIV) by taking } \\
\text { birth control pills? }\end{array}$} \\
\hline Yes. & 8.9 & 11.4 & 17.8 & 6.8 \\
\hline No & 80.0 & 81.5 & 74.9 & 83.7 \\
\hline Not sure . & 11.1 & 7.1 & 7.3 & 9.5 \\
\hline \multicolumn{5}{|l|}{ 33. Can AIDS be cured if it is diagnosed early? } \\
\hline Yes ................... & 12.1 & 11.2 & 20.1 & 8.2 \\
\hline No & 78.2 & 78.9 & 67.6 & 82.3 \\
\hline Not sure ..... & 9.6 & 9.9 & 12.3 & 9.5 \\
\hline \multicolumn{5}{|l|}{ 34. Can you catch AIDS by sharing needles/syringes with someone who has the AIDS virus? } \\
\hline 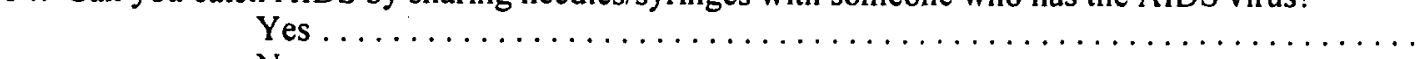 & 81.8 & 83.4 & 76.7 & 85.0 \\
\hline 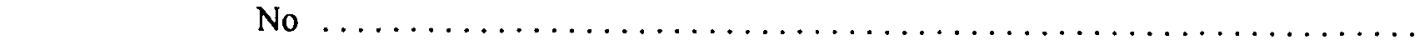 & 14.3 & 13.8 & 16.4 & 8.2 \\
\hline Not sure & 3.9 & 2.8 & 6.8 & 6.8 \\
\hline
\end{tabular}


Table 36. Percentage of HIV/AIDS Related Sexual Behavior by Length of Attendance at Seventh-day Adventist Schools

\begin{tabular}{|c|c|c|c|c|}
\hline \multirow{2}{*}{ Behavior Item } & \multicolumn{4}{|c|}{ Years by percent } \\
\hline & $0-1$ & $2-6$ & $7-10$ & $11+$ \\
\hline 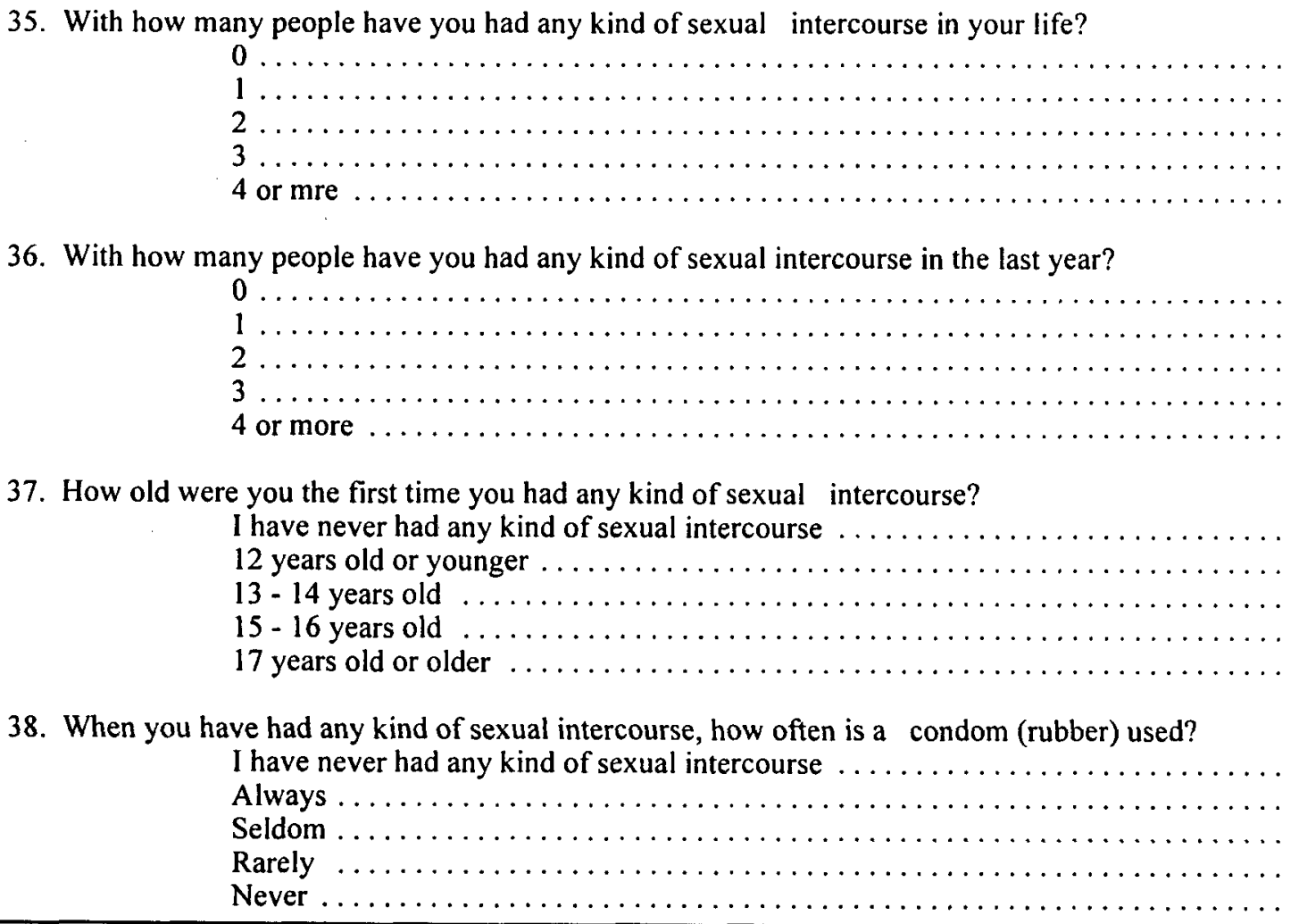 & $\begin{array}{r}75.7 \\
5.0 \\
6.8 \\
4.3 \\
8.2 \\
\\
\\
81.8 \\
7.1 \\
4.6 \\
1.8 \\
4.6 \\
\\
\\
76.1 \\
5.4 \\
5.4 \\
9.3 \\
3.9 \\
\end{array}$ & $\begin{array}{r}73.6 \\
6.3 \\
4.5 \\
10.1 \\
5.5\end{array}$ & $\begin{array}{r}74.0 \\
5.5 \\
5.0 \\
1.8 \\
13.7\end{array}$ & $\begin{array}{r}73.5 \\
8.2 \\
3.4 \\
2.7 \\
12.2\end{array}$ \\
\hline
\end{tabular}


Table 37. Percentage of HIV/AIDS Related Sexual Behavior Responses by Extent to Which Students Talk to Their Parents.

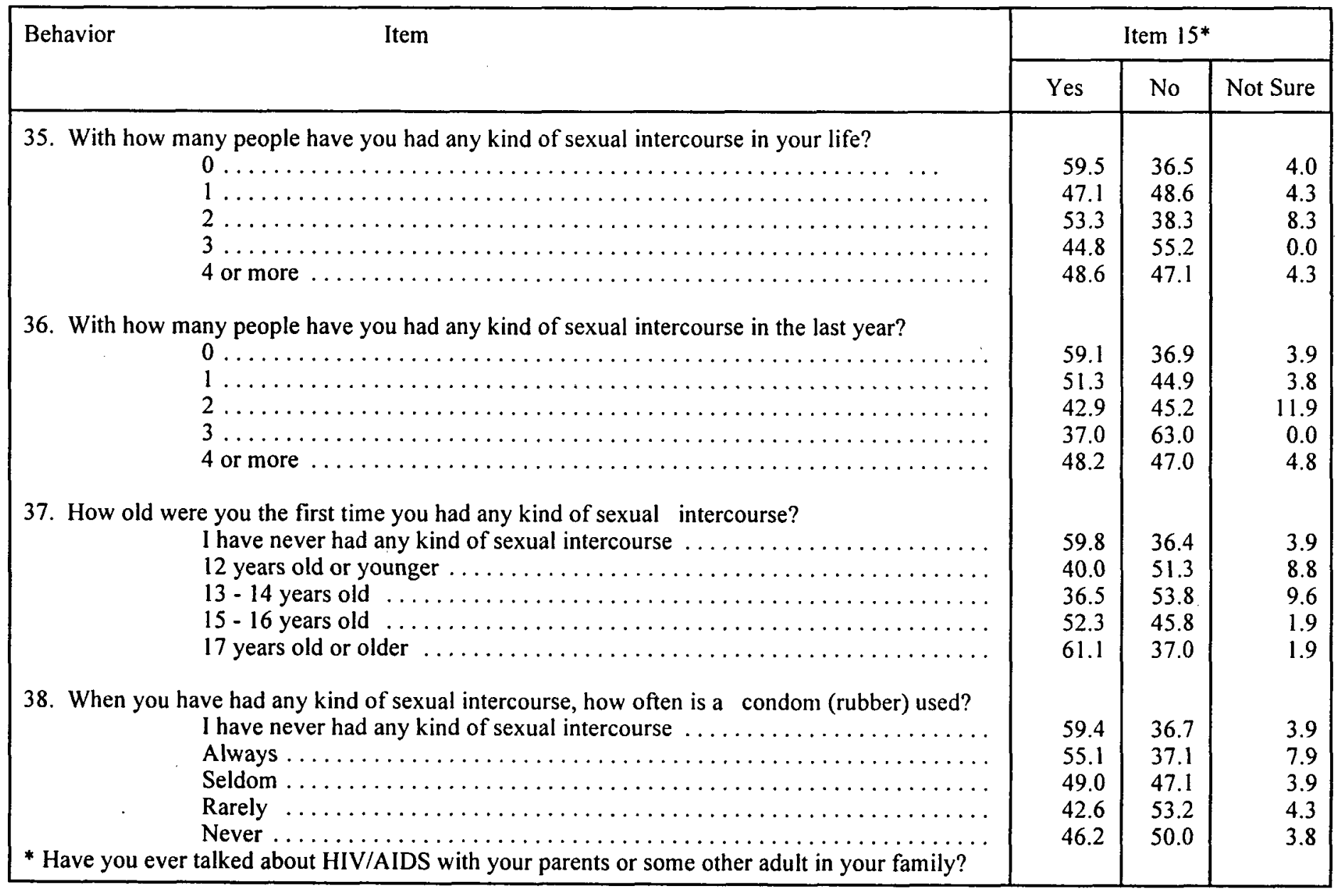


APPENDIX B

CORRESPONDENCE 
phah tre 3400 a6

Tet, No.3\$ 0006 Akaki

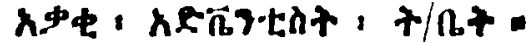

Akaki Adventist School

AKAKI-BESSEKA
PyT3, ATC las

P.O. $80 \times 145$

ADDIS $\triangle B A B A$

$$
\text { Ref. \# } \frac{A \cdot A \cdot S \cdot 191 / 95}{\text { March } 16,1998}
$$

\section{Mrs. Debora Herold}

Ethiopian Adventist College

P.O.Box 45

Shashemane,Ethiopia

\section{Dear Mrs. Herold.}

In your letter dated March 15, 1998, you requested us for our permission \& cooperation to conduct HIV/AIDS survey questionnaire in our secondary school which will be part of the requirements for your Master of Science degree.

Therefore, I am pleased to inform you that we will assist you in conducting the survey and you are kindly asked to give the survey questionnaires to students as schedule herebelow.

a. Grades $9-11$ on March 19.1998 at 10:00 A.M.

b. Grade 12 on March 23, 1998 at 10: 00 AM.

May I wish you a success in your education and our school will be very grateful to you if you could furnish a copy of your Masterial thesis in future.

Sincerely yours.

$x+2$

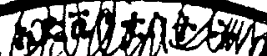

/3H Addise Ansepo.

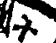

$3 \mathrm{H}$

Principal.
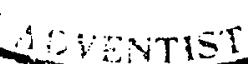
Ato Abebe Disasa

Debora Herold

Box 45

Ethiopian Adventist College

Shashemene, Ethiopia

March 3, 1998

Education Director

Ethiopia Union Mission

Addis Ababa, Ethiopia

Dear Ato Abebe,

AIDS has become a leading cause of death among people ages $20-29$. When we consider the fact that the average time interval between becoming infected with the virus and developing AIDS is about seven years, most of these people would have been infected when they were adolescents.

As part of the requirements for my Master of Science in Administration degree from Andrews University I am desiring to conduct a survey in order to help our young people avoid ADS high-risk related behaviors by gaining a greater understanding of their needs. I would like to conduct a survey to study the AIDS-related knowledge, attitudes, and behaviors of students attending Kuyera, Akaki, and Dongoro Seventh-day-Adventist academies (grades 9 through 12). All students, day and boarding, will be included in the study. The study will endeavor to find out the degree that family, church, and school may influence AIDS-related knowledge, attitudes, and behaviors.

This will be a one time survey in which I will visit all three institutions and administer the survey with assistance:

Please assist me with the following:

1. Letter of permission, authorizing me to carry on this survey in the above mentioned academies.

2. : The number of students (day and boarding ) currently enrolled in each of the academies.

3. . : The name of a contact person in each academy that I can coordinate with for date, times and logistic purposes.

4. Letter to each of the academies notifying them of my intention, future correspondence, and your permission.

Thank you very much for your assistance and guidance in the past and again at this time. I will be awaiting your letter of reply.

Sincerely yours,

Debora Herold 


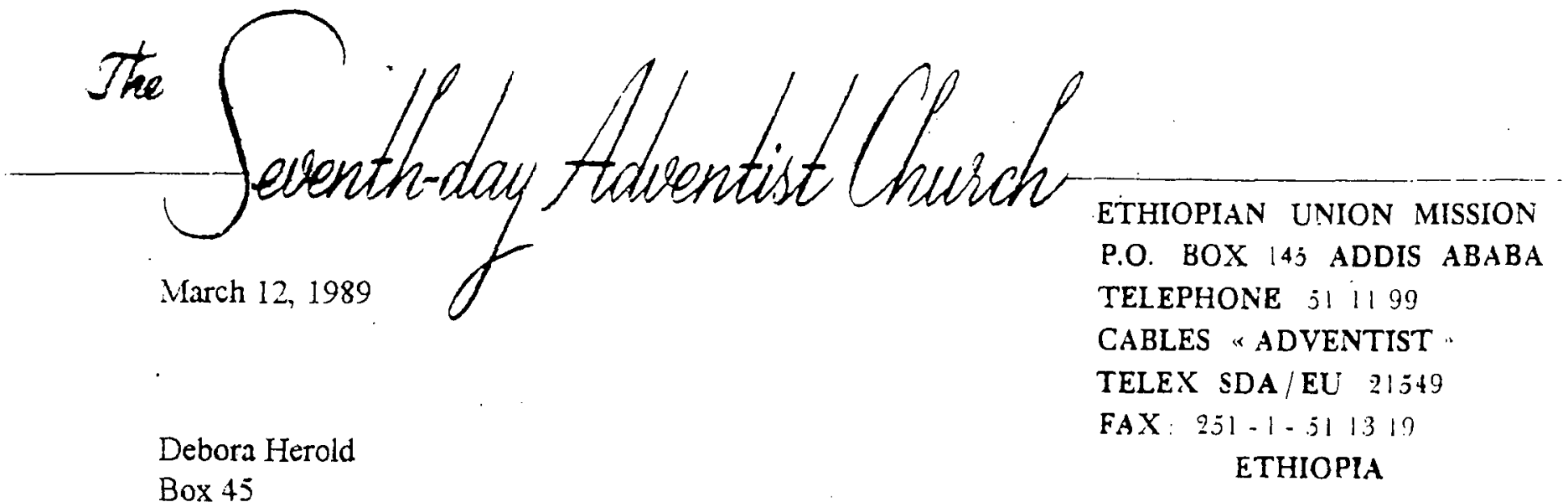

Ethiopian Adventist College

Shashemene, Ethiopia

Dear Mrs Herold:

I am writing this letter in recognition of vour letter of :Warch 3. 1998 regarding your interest to conduct a survey in order to help our young people avoid. ADS -risk related behaviors by gaining a greater understanding of their needs.

First of all. I'd like to express my appreciation for choosing our schools for your studies, because this study is the first one of its kind in our schools and I say it is timety.

As far as student enrollment is concerned.

Ethiopia Adventist College Acaderny - 338
Akaki Adventist Academy -
Wollega Adventist Academy -
-

Your contact persons are as follows.

1. Akaki Adventist School:-

2. Wollega Adventist Academy:-

3. Ethiopia Adventist College Academy -

Ato Addise Ansebo. Principal Mismaku Yazachew, Principal Alaka Anota Principal

Finally, by this letter Ethiopian Union Education Department gives you permission to conduct research at KAA. WAA and Akaki.

I wish you success in your project may God bless you in His service.

Sincerety yours,

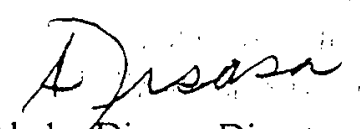

tbebo Disasa Director

EduCation Department

Ethiopian Union Mission of SDA 


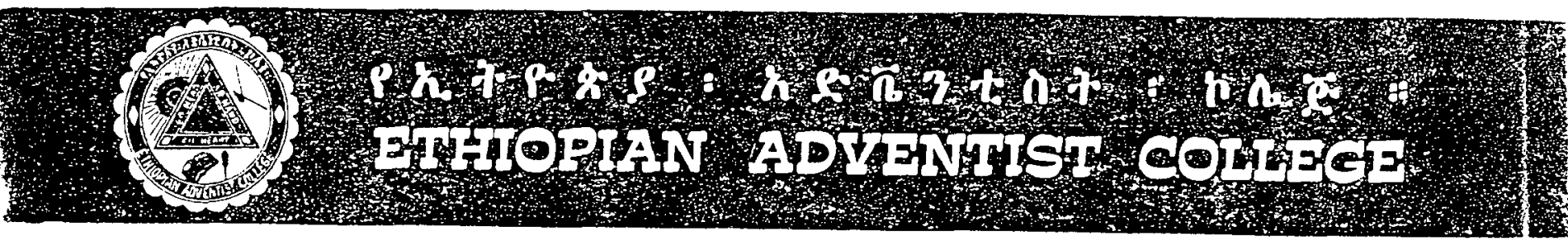

p. $0.80 x+5$ shashamane

p. $0.80 \times 145$ doO15 $1828 d$

Alo tlaka Anota

Principa!

Nuyera Adventist Academy

Shashemene. Ethiopia

varch 151998

Dear Mrs Debora Herold.

Thank you for your letter requesting to conduct a survey in our .istlution. ADS is a very devestating disease and we are willing to participate in your research in an effort to help our vouth.

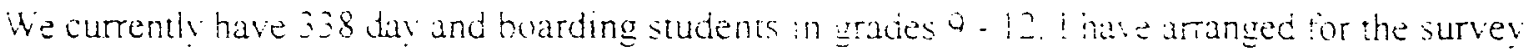
to be conducted as follows on March 16 . 1908

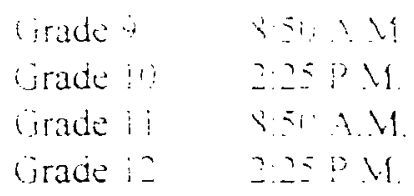

i wish you sucess in your profect and may God bless you in His servee

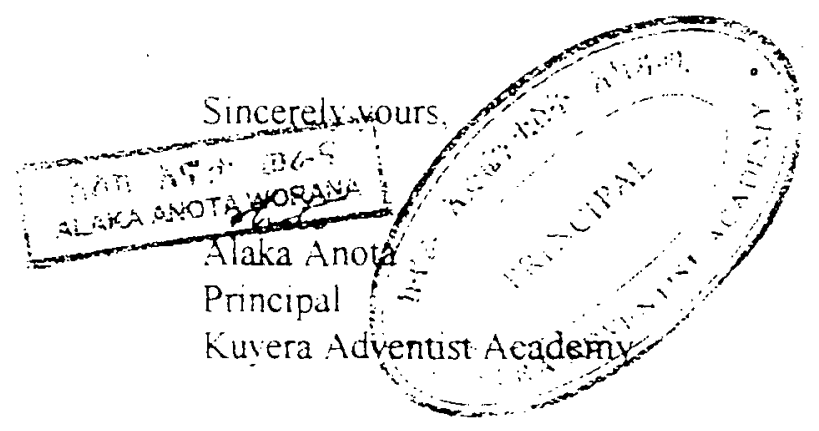




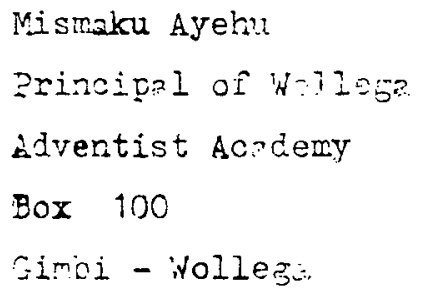

Miss Debora Herold

20x 45

Thiopian Adrentist Collage

Shashemene, Ithiopia

$D=\because$ Madam

Tretirgs by thio lettaz. vour aisistant sto samson Lema has arived at Dongoro on march 18,1998 with your letter dated march 15,1998. He has 5 iven all the necessary assistance from ou acadery per your zequest and has leev working on the yuestionairas in our acadedy for two days (19-20/03/98). Accordingly.

\begin{tabular}{|c|c|c|}
\hline Grade & $\begin{array}{l}\because \text { Oo students in the } \\
\text { grade this year }\end{array}$ & $\begin{array}{c}\text { No students firled } \\
\text { the questionaires, }\end{array}$ \\
\hline$a$ & 70 & 66 \\
\hline 10 & 68 & 62 \\
\hline 11 & 73 & 72 \\
\hline 12 & 50 & 38 \\
\hline Total & 261 & 238 \\
\hline
\end{tabular}

AlI the conpleted 238 questionnaires are enclosed in an envelope and handed to a to Scmson to be harded ouer to you.

This days AIDS is highly affecting individuals, families, economic growth and sccial development at large. There fore any sort of study in this regard is appreciable。

May uod bless your work so that it bears frult for nations.

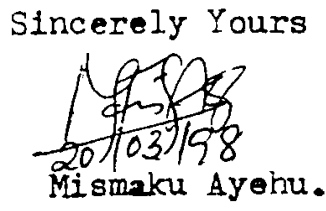


APPENDIX C

SURVEY QUESTIONNAIRE 


\section{SURVEY}

AIDS is a very serious health problem in our Nation. Health officials are trying to find the best ways to teach people about AIDS and the human immunodeficiency virus (HIV), that causes AIDS. This survey has been developed so you can tell us what YOU know and how YOU feel about HIV/AIDS. The information you give will be used to develop better HIV/AIDS education programs for young people like yourself.

DO NOT write your name on this survey!! The answers you give will be kept private. No one will know what you write. Please tick $(\checkmark)$ the response that best answers the questions based on what you really know, feel, or do. Please answer all the questions.

The questions in Part I that ask you about your background will only be used to describe the types of students completing this survey. The information will not be used to find out your name. No names will ever be reported.

You need to understand two related words used in this survey: AIDS and HIV

- AIDS stands for acquired immunodeficiency syndrome

- AIDS is caused by the virus, HIV

- HIV stands for human immunodeficiency virus. HIV is the virus that causes AIDS.

THANK YOU VERY MUCH FOR YOUR HELP. 
Part 1

Read each question carefully. Mark the response that best answers the questions based on what you really know, feel, or do. Please answer all of the questions.

1. What grade are you in? $\square$ 9th $\square$ 10th $\quad \square$ 11th $\square$ 12th $\square$ other hF:A

2. What is your gender? $\square$ Female $\square$ Male g,

3. How old are you? $\square 12-13 \square 14-15 \square 16-17 \square 18-19 \quad \square 20-21 \square 22-23$ of.ro?

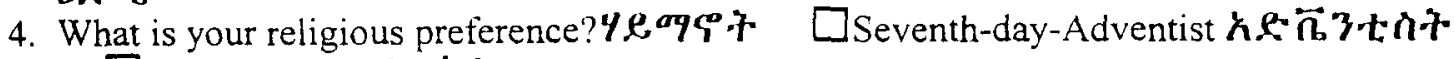

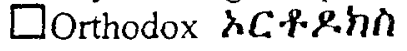

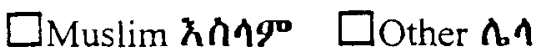

5. What is the extent of your Adventist affiliation? Mark all responses that apply to you.

$\square$ Baptized member $\mathbf{T} \mathbf{n}^{\circ} \mathbf{\phi} \mathbf{4} \quad \square$ One or both parents baptized members

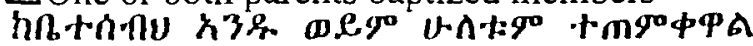

$\square$ Raised in an Adventist home $\square$ None

nरer

6. How long have you attended a Seventh-day-Adventist school? A久s: $2 \%, 9+$ + $+9^{\circ} \angle Y A$ !

$\square 0-1$ Years $\square 7-10$ years

$\square 2-6$ Years $\square 11$ years or more

Part II

Read each answer carefully. Select the response that best answers each question based on what you really know, feel, or do.

7. Should students your age be taught about HNV/AIDS infection in school?

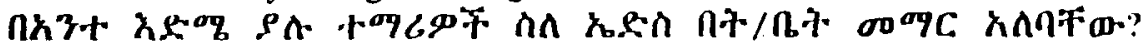

8. Have you been taught about HIV/AIDS infection in school?

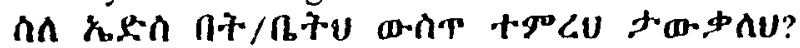

9. Should a student with HIV/AIDE infection be allowed to go to your school?

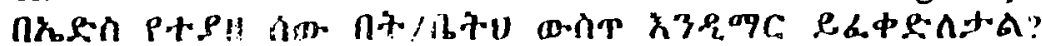

10. Would you be willing to be in the same class with a student with HIV/AIDS infection? $\square$

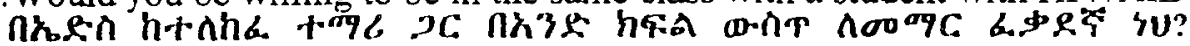

11.Do you know where to get good information about HIV/AIDS infection?

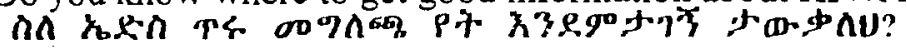

12.Do you know where to get tested to see if you are infected with the AIDS virus?.

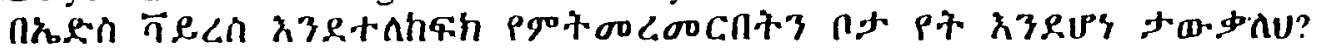

13.Do you know how to keep from getting the HIV/AIDS virus?.

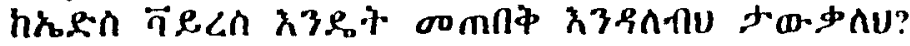

14. Have you ever talked about HIV/AIDS with a friend?.

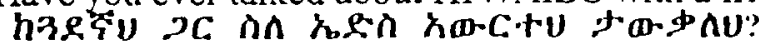


15. Have you ever talked about HIV/AIDS with your parents or some other adult in your family?

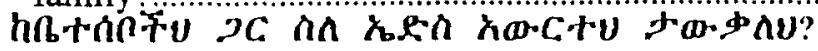

16.Can a person get HIV/AIDS infection from holding hands with someone?

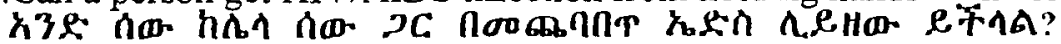

17.Can a person get HIV/AIDS infection from sharing needles used to inject drugs?

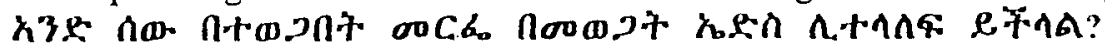

18. Can a person get HIV/AIDS from being bitten by a mosquito which has already fed on a person with AIDS...

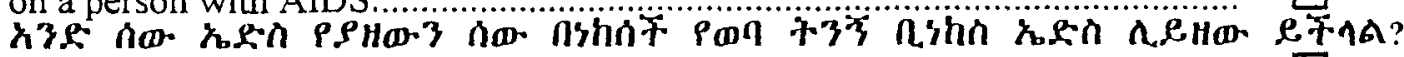

19. Can a person get HIV/AIDS from donating blood?

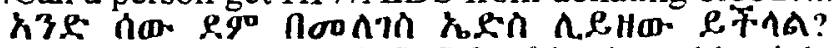

20.Can a person get HIV/AIDS from having a blood drawn with a sterile

needle?

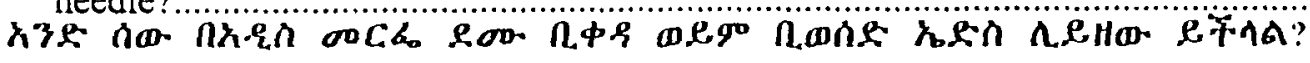

21.Can a person get HIV/AIDS infection by wearing clothes used by someone who has the AIDS virus?

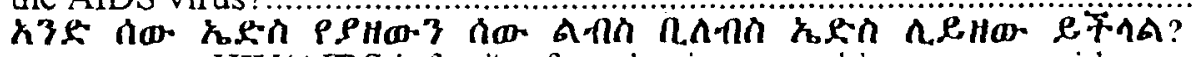

22. Can a person get HIV/AIDS infection from having sexual intercourse without using a condom (rubber)?

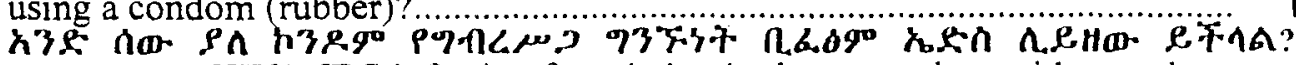

23.Can a person get HIV/AIDS infection from being in the same class with a student who has AIDS/HIV infection?.

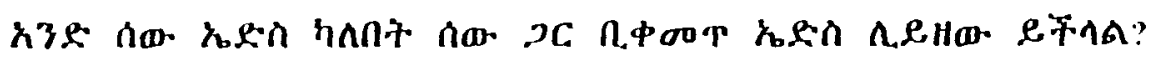

24.Can you tell if people are infected with the AIDS virus (HIV) just by looking at them?

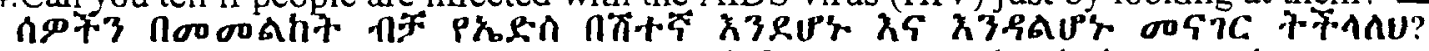

25.Can a person who has the AIDS virus (HIV) infect someone else during sexual intercourse?

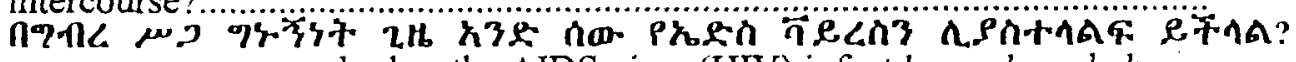

26.Can a pregnant woman who has the AIDS virus (HIV) infect her unborn baby with the virus?

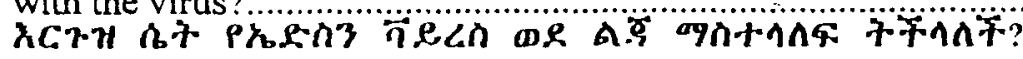

27. Is there a cure for HIV/AIDS infection?.

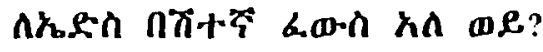

28. Is it true that only homosexual men can get the HIV/AIDS infection?

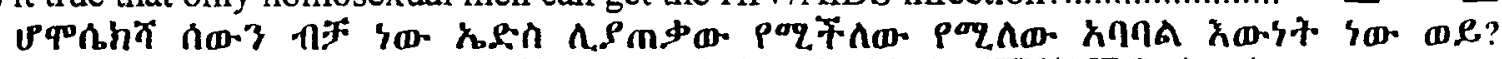

29. Can people reduce their chances of becoming infected with the HIV/AIDS virus by not having any kind of sexual intercourse (being abstinent)?

exin?

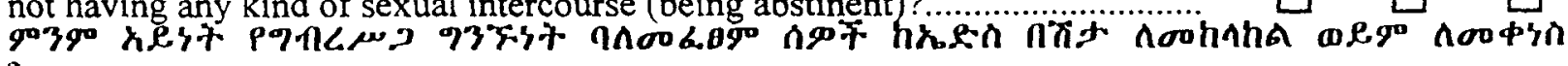

30. Can people reduce their chances of becoming infected with the AIDS virus (HIV) by using condoms (rubbers) during sexual intercourse?

e完rn?

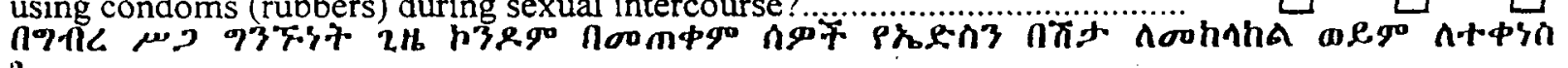

31. Can people reduce their chances of becoming infected with the AIDS virus (HIV)

by not having any kind of sexual intercourse with a person who has injected

(shot up) drugs?. 的策 $\square$

ntit noothi oego noohnha exin?

32. Can people reduce their chances of becoming infected with the AIDS virus (HIV) 
by taking birth control pills?

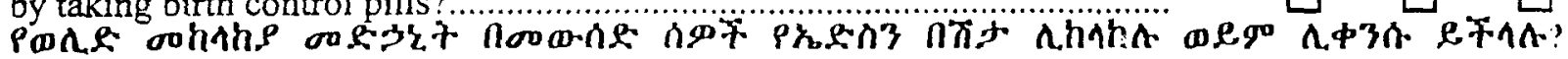

33. Can AIDS be cured if it is diagnosed early?

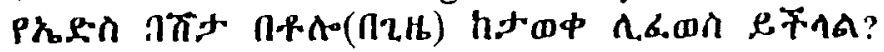

Part III

34. Can you catch AIDS by sharing needles/syringes with someone who has the AIDS virus?

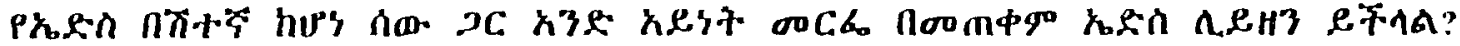

Read each question carefully. Select the response that best answers each question based on what you really know, feel, or do.

35. With how many people have you had any kind of sexual intercourse in your life?

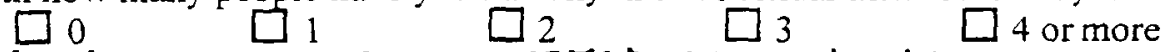

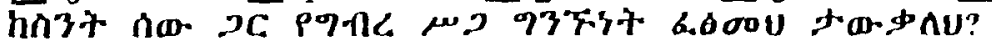

36. With how many people have you had any kind of sexual intercourse in the last year?

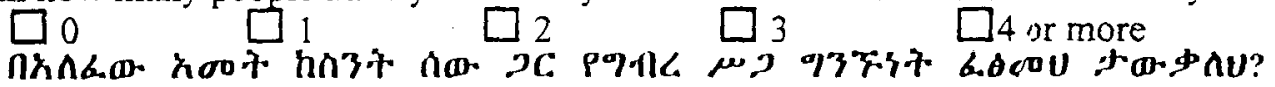

37. How old were you the first time you had any kind of sexual interccurse?

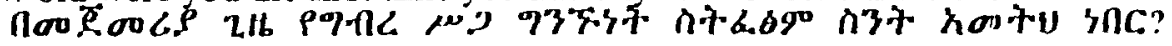

$\square$ I have never had any kind of sexual intercourse.

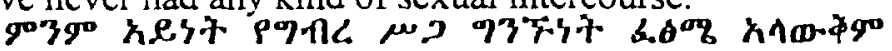

12 years old or younger

12 久ont wego h4 not.

$\square 13-14$ years old

$\square 15-16$ years old

$\square 17$ years old or older

38. When you have any kind of sexual intercourse, how often is a condom (rubber) used?

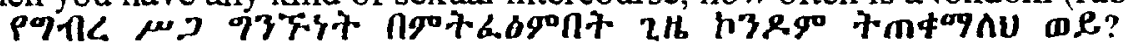

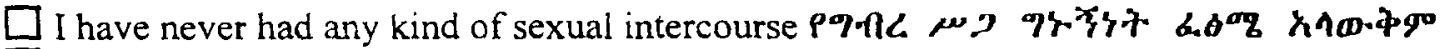

$\square$ Always w口ik

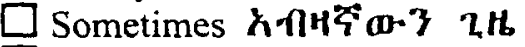

$\square$ Rarely $\$ 3.93 \%$ : $\mathrm{H}$

$\square$ Never חF:0.9०

THANK YOU VERY MUCH FOR YOUR TIME AND HELP hoon\%snu. 
BIBLIOGRAPHY 


\section{BIBLIOGRAPHY}

A statement about AIDS from the Seventh-day Adventist Church. (1998). Unpublished manuscript, in my possession.

AIDS Analysis Africa. (1998, December-January, 1999). Vol. 4, issue 9, pp. 7, 8.

AIDS in Ethiopia. (1998). Addis Ababa: National AIDS/STD Control Programme.

AIDS in Ethiopia, background, projections, impacts, interventions. (1996, August).

Addis Ababa: Epidemiology and AIDS Department of the Ministry of Health.

AIDS in Kenya. (1998). Nairobi: National AIDS/STD Control Programme.

Anderson, J.E., Kann, L., \& Holtzman, D. (1990, November/December). HIV/AIDS knowledge and sexual behavior among high school students. Family Planning Perspectives, 22(6), 252-255.

Balsey, C. (1989). A survey of knowledge, beliefs and selected behavioral practices related to acquired immunodeficiency syndrome among urban $10^{\text {th }}$ grade public high school students. Ph.D. dissertation, Temple University.

Basen-Enquist, K., \& Parcel, G. (1992). Attitudes, norms, and self-efficacy: A model of adolescents' HIV-related sexual risk behavior. Health Education Quarterly, 19(2), 263-277.

DiClemente, R. J. (1993, April). Confronting the challenge of AIDS among adolescents directions for future research. Journal of Adolescent Research, 8(2), 156-166.

Dixon, P. (1994). The truth about AIDS. Eastbourne, England: Kingsway.

Dryfoos, J. G. (1990). Adolescents at risk. New York: Oxford University Press.

Endris, A. (1993, October). Project helps build sexual responsibility. Network, Family Health International 14(2), 28.

Ethiopia country health profile. (1996). Addis Ababa, Ethiopia: Ministry of Health. 
Evans, A. (1992). Guiding your family in a misguided world. Milton Keynes, England: Word (UK).

Family Guidance Association of Ethiopia. (1991). Addis Ababa: Family Guidance Department of the Ministry of Health.

Fantahun, M., \& Chala, F. (1996, October). Ethiopian Medical Journal, 34(4), 233-242.

Gebre, S. (1990). Sexual behavior and knowledge of AIDS and other STDs: A survey of senior high school students. Ethiopian Journal of Health Development, 4(2), 123124.

Grunseit, A., \& Kippax, S. (1997). Sexual education and young people's sexual behavior: A review of studies. Journal of Adolescent Research, 2(4).

Howell, M. F., Hillman, E.R., \& Blumberg, E. (1994). A behavioral-ecological model of adolescent sexual development: A template for AIDS prevention. The Journal of Sex Research, 3l(4), 267-281.

Ignatavicius, D., Workman, L., \& Mishler, M. (1995). Medical-surgical nursing. Philadelphia: W.B. Saunders Company.

Johnston, A. (1997). HIV/AIDS prevention youth programs in Africa. UK/USA: Futures Group.

Kann, L., Nelson, G., Jones., \& Kolbe, L. (1989). Establishing a system of complementary school-based surveys to annually assess HIV-related knowledge, beliefs, and behaviors among adolescents. Journal of School Health, 59(20), 5558

Kariuki, A. (1998). Information package on HIV/AIDS and adolescents. Kenya AIDS NGOs Consortium, 3, 24.

Kerkhoven, R. (1998). Where are we heading with HIV/AIDS in Sub-Saharan Africa? AIDS Analysis Africa, 8(1), 4.

Khodakevich, L., Mengistu, H.N., \& Bekele, S. (1990). Projections on the development of HIV/AIDS epidemics in Ethiopia. The Ethiopian Journal of Health Development, 4(1), 191 -195.

LaPierre, D. (1991). Beyond love. New York: Warner Books.

Ludescher, G. (1992). Aids-related knowledge, attitudes, and behaviors in adolescents attending Seventh-day-Adventists schools in California. Ph.D. dissertation, Loma Linda University, Loma Linda, CA. 
Main, D., Iverson, McGloin, Banspach, Collins, Rugg, \& Kolbe. (1994). Preventing HIV infection among adolescents: Evalutaion of a school-based education program. Preventive Medicine 23, 409-417.

Mann, J. M., \& Petitgirard, A. (1995). Health care on women and children in developing countries. Oakland, CA: Third Party Publishing Company.

Mann, J. M., \& Tarnatola, D. (1998, July). HIV 1998: The global picture. Scientific American, 82-3.

Massachusetts youth risk behavior survey results. (1995). Boston: Massachusetts Department of Education.

Morbidity and Mortality Weekly Report. (1993). 42, RR-14, pp. 3, 5, 9.

Negerie, M. (1998). Maternal and child health-supplement. Silver Spring, MD: Adventist Development and Relief Agency, International.

Network, Family Health International. (1993, October). Vol. 14, issue 2.

Otis, D. Teach your children well. Colorado Springs, CO: Focus on the Family.

Petros, B., Belayneh, S., \& Mekonnen, Y. (1997). AIDS and college students in Addis Ababa: A study of knowledge, attitude and behavior. The Ethiopian Journal of Health Development, 2(2), 115-123.

Resnick, Bearman, Blum, Bauman, Harris, Jones, Tabor, Beuhring, Sieving, Shew, Ireland, Bearinger, \& Udry. (1997, September 10). Protecting adolescents from harm. The Journal of the American Medical Association, 2-22.

Rosensvard C., \& Campbell, T. (1996, July 7-10). International Conference on AIDS. Abstract no. Mo.D.1831.

Sessional paper no. + of 1997 on AIDS in Kenya. (1997). Nairobi, Kenya: Government Printer.

Seventh-day Adventist church mamual. (1995). Hagerstown, MD: Review and Herald Publishing.

Seventh-day Adventist Church and the AIDS epidemic-Guidelines. (1996, September 27). Silver Spring, MD: Health and Temperance Department, General Conference of Seventh-day Adventists.

Seventh-day Adventist yearbook. (1997). Hagerstown, MD: Review and Herald Publishing. 
Smedes, L. (1992). Sex for Christians. New York: William B. Eerdmans.

St. Lawrence, J. S. (1993). African-American adolescents' knowledge, health-related attitudes, sexual behavior, and contraceptive decisions: Implications for the prevention of adolescent HIV infection. Journal of Consulting and Clinical Psychology, 61(1), 104-112.

Stafford, T. (1993). Sexual chaos. Downers Grove, IL: InterVarsity Press.

Teka, T. (1993, October). Ethiopian Medical Journal, 3I(4), 233-7.

Tshimika, P. K.. (1991). Predictors of HIV-related high risk sexual behavior among adolescents from church-related high schools in the Bandudu Province-Zaire. Ph.D. dissertation, Loma Linda University, Loma Linda, CA.

Twelfth world AIDS conference. (1998, July 10). Call to arms. Conference conducted at the International AIDS Conference in Geneva, Switzerland.

United Nations AIDS. (1997).

Values: Will our children carry the torch? (1991, February). Vibrant Life, p. 28.

W/yohannes, M. (1996, October). AIDS Analysis Africa, 6(5), 9.

Williams, R., \& Ponton, L. (1992). HIV and adolescents: An international perspective. Journal of Adolescence, 15, 335-343.

Wood, G., \& Dietrich, J. (1990). The AIDS epidemic, balancing compassion and justice. Portland, OR: Multnomah. 